\title{
Hydrological Drought Index Insurance for Irrigated Agriculture
}

\section{TESIS DOCTORAL}

Teresa Maestro Villarroya

Ingeniera Agrónoma

\section{Directores}

María Bielza Díaz-Caneja

Dr. Ingeniero Agrónomo

Alberto Garrido Colmenero

Dr. Ingeniero Agrónomo

Madrid 2016 

"Ingeniamos el futuro"

Tribunal nombrado por el Sr. Rector Magfco. de la Universidad Politécnica de Madrid, el día de de $201 \ldots$

Presidente:

Vocal:

Vocal:

Vocal:

Secretario:

Suplente:

Suplente:

Realizado el acto de defensa y lectura de la Tesis el día de de $201 \ldots$ en la E.T.S.I./Facultad

Calificación

EL PRESIDENTE

LOS VOCALES

EL SECRETARIO 





\section{Agradecimientos}

Llegó el momento de redactar los agradecimientos, y recordar a todas las personas que me han acompañado en este recorrido y que me han ayudado a finalizar el doctorado. El pararse a pensar sobre todo lo que tenemos que agradecer a las personas que nos rodean, es un ejercicio que deberíamos hacer más a menudo, sin tener por ello que redactar una tesis cada vez.

Para empezar quiero dar las gracias a mis dos tutores, María Bielza y Alberto Garrido. María me abrió las puertas del CEIGRAM y me dio la oportunidad de colaborar con ella en el proyecto "Un seguro de sequía hidrológica para la agricultura de regadío como instrumento de adaptación al cambio climático", gracias a lo cual recibí una beca FPI del Ministerio de Economía y Competitividad para la realización del doctorado, que me ha dado tranquilidad y estabilidad económica durante los últimos 4 años. Gracias María, por todas las oportunidades que me has dado, tu cercanía, tu dedicación y tus consejos. Alberto Garrido ha seguido muy de cerca toda mi investigación, pero debo de agradecerle sobre todo su papel en la última parte de la tesis, fundamental para culminar este trabajo. Alberto, muchas gracias por tu apoyo, eficacia y por todos los ánimos que me has dado.

En el proyecto he tenido la suerte de colaborar además con Jorge Ruiz, Ana Iglesias, Felipe Medina, Gabriela Jiménez y Alberto Algarra. También quiero dar las gracias a todos los que participaron en el seminario del proyecto.

La beca FPI me ha dado además la posibilidad de acceder a ayudas para la realización de estancias en otras universidades. La primera fue en la Universidad de Catania (Italia), donde debo de agradecer la ayuda de Antonio Cancelliere, Vincenzo Nicolosi, David Peres y Brunella Bonaccorso, así como la compañía de mis incansables compañeros de despacho, Claudio e Ilaria. La segunda estancia fue en la Universidad de Mississippi (Estados Unidos). Allí tuve el honor de trabajar con dos grandes expertos en seguros agrarios, Barry Barnett y Keith Coble, con los que hemos escrito uno de los artículos que forman parte de esta tesis, muchísimas gracias por vuestra contribución. También asistí a la clase de Ardian Harri, con quien disfruté de la econometría. Debo de agradecer especialmente la ayuda de Barry en todos los aspectos y la compañía y complicidad de Dee Barnett, que me hizo sentir como en casa durante la estancia. Por cierto, nunca he madrugado tanto los sábados, como para ir a correr con Becky y Cade Smith y los Broadtown runners.

La realización de esta tesis no hubiera sido posible sin el apoyo del CEIGRAM y del Departamento de Economía Agraria. Gracias a Inés Mínguez, a Esperanza, Katerina, Isabel 
Bardají, Ana Tarquis, Isabel Peregrina y Begoña. Gracias también a todos los profesores y compañeros del Máster de Economía Agraria, con quienes empecé este largo camino.

Gracias a los compañeros del CEIGRAM: A Jorge, compañero de proyecto, con quien ha sido un gusto trabajar y compartir muchos momentos a lo largo de estos años, a Berta, que me ha animado mucho en la recta final, única donde las haya y igran conversadora!, a Paula por su buen humor, alegría y energía, ¡qué pena me dio cuando te fuiste!, a las Bárbaras y a Insa, con las que tengo algo en común... ¡ser madre!, a Ana Felis por su dulzura, a Axel, Marinas, Lola, Gloria, Dani, Elena y a todos los demás, ;por ponerme de tan buen humor siempre que he ido al CEIGRAM!

Gracias a todos los amigos roceños, que aunque cada vez nos veamos menos, sé que siempre puedo contar con vosotros. ¡Gracias Nico por revisarme el resumen de la tesis! Y por último, gracias a mi familia. Gracias a Montse, Armando y Ainhoa, por cuidarnos tanto y estar tan pendientes de nosotros. Gracias a papá y a Laura. Por estar ahí en todas las etapas de mi vida, por apoyarme incondicionalmente y animarme en cada proyecto. Gracias a mi sobrino Isul, que de pensar en él me entran ganas de reír con sus juegos. Gracias a mamá, cuánto me hubiera gustado tenerte aquí y ahora. Gracias a Néstor, mi vida, siempre a mi lado estos últimos años. Por último, gracias a Benjamín por alegrarme cada mañana desde que llegó al mundo. Os quiero.

¡Gracias a todos! 


\section{Resumen}

Los riesgos de escasez de agua en sistemas de regadío son importantes en los países semi-áridos y es probable que aumenten debido al cambio climático. De ahí deriva el interés en ofrecer a los agricultores la posibilidad de proteger la estabilidad de los ingresos de las explotaciones de regadío frente a este riesgo. Debido a las dificultades que un seguro de este tipo presenta, solamente un país (Estados Unidos) ofrece esta cobertura bajo un seguro multi-riesgo. Sin embargo, la cobertura es muy limitada para evitar problemas de selección adversa y riesgo moral.

El objetivo de la tesis es proponer un seguro de sequía hidrológica para los cultivos de regadío, que sea eficaz, fácil de implementar, compatible con los mercados de agua y que pueda adaptarse a las leyes actuales de seguros agrarios. El seguro propuesto se fundamenta en un seguro tipo índice que indemniza a los asegurados según el valor que toma un Indicador de Sequía (IS) seleccionado. El seguro cubre las pérdidas económicas o aumento de costes producidos en situaciones extraordinarias de escasez de agua, y cuenta con la valoración positiva de un panel de expertos (Capítulo 3).

Este tipo de seguro ya ha sido estudiado en la literatura, pero en esta tesis se profundiza en determinados aspectos clave para su desarrollo e implementación, como la selección y validación del Índice de Sequía Hidrológica (IS) y la estimación de la indemnización unitaria. La tesis afronta asimismo la importancia de la problemática de los sistemas con inercia (con capacidad de almacenamiento muy superior a aportes), donde la escasez de agua se puede predecir al inicio de la campaña agrícola, que suele coincidir con el momento de contratar el seguro. Este hecho puede ocasionar una selección adversa temporal que es importante considerar a la hora de diseñar el seguro.

El Capítulo 3 ofrece el desarrollo metodológico de un seguro tipo índice para sistemas sin inercia. En este capítulo se emplean métodos de valoración de agua para estimar la indemnización unitaria que recibirá el asegurado, basada en la productividad agraria y que varía según la dotación de agua de riego recibida. En los Capítulos 4 y 5, aplicados a sistemas con inercia, se ofrece el desarrollo metodológico de diversos esquemas diseñados para hacer frente al riesgo de selección adversa temporal. Las metodologías se ilustran mediante la aplicación a tres estudios de caso: Riegos de Bardenas en España (Capítulo 3), zona regable de El Viar en España (Capítulo 4), y el Valle Central de California en Estados Unidos (Capítulo 5).

Respecto a la selección y validación del Índice de Sequía Hidrológica (IS), el IS está basado en variables hidrológicas. Como novedad en esta tesis, se propone que el IS también pueda estar 
basado en reglas institucionales que determinan el reparto de agua en la zona regable. La validación del IS está basada en el estudio detallado del Riesgo Base (gran inconveniente de los seguros tipo índice) que es la diferencia entre la pérdida económica estimada por el IS y la pérdida económica realmente sufrida por el asegurado.

Para hacer frente a la selección adversa temporal se proponen diferentes esquemas de seguro. El primero de ellos es establecer una prima variable o bien una franquicia variable en base a la previsión de disponibilidad de agua para la campaña de riego asegurada. En el Capítulo 5 las primas oscilan entre $8 \%$ y el $24 \%$ sobre el valor asegurado según la previsión de sequía. En el Capítulo 4 se observan diferencias aun mayores, oscilando la prima entre el $0 \%$ y el $41 \%$ sobre el valor asegurado. Debido a estas grandes diferencias, en el Capítulo 4 se analiza un contrato de seguro plurianual. Para el escenario de sequía más desfavorable, la prima del seguro se rebaja del $41 \%$ al $26 \%$ para un contrato de tres años. Como alternativa, también se propone establecer un periodo de contratación del seguro anterior al momento en que es posible prever la disponibilidad de agua para la campaña de riego que se asegura (contratos early-bird). En sistemas con inercia, los resultados indican que los contratos early-bird son los más eficaces en reducir la exposición al riesgo. En los dos estudios de caso con inercia analizados (El Viar y Central Valley, Capítulos 4 y 5), la prima calculada es de $13 \%$ y $14 \%$ sobre el valor asegurado para una cobertura del $100 \%$, bastante superior a la prima calculada para el estudio de caso de Riegos de Bardenas (sistema sin inercia), que oscila entre $0.4 \%$ y $1.8 \%$ sobre el valor asegurado. Esto muestra que los sistemas con inercia, más complicados de asegurar, son precisamente aquellos con mayores riesgos, donde las sequias son más intensas y por tanto el seguro es más necesario.

En los Capítulos 3 y 5 se ha analizado además la efectividad de reducir los riesgos de la escasez de agua con diferentes recargos sobre la prima para cubrir costes administrativos y de operación de las aseguradoras. A pesar de los recargos, el seguro sigue siendo eficaz en reducir el riesgo de sequía, lo que demuestra que existe una oportunidad de mercado para las compañías aseguradoras.

A pesar de las limitaciones de los estudios de caso, sobre todo en cuanto a disponibilidad de datos, los resultados muestran que el seguro se puede adaptar a diferentes zonas de riego, y que proporciona una mayor estabilidad económica a los regantes. Futuras investigaciones podrían explorar la demanda de este tipo de seguros y analizar en profundidad su interacción con los mercados de agua. 


\section{Summary}

Water supply risks are significant in semi-arid countries and might become more severe due to climate change. From this stems the interest in offering farmers the possibility of insuring their farm incomes against water shortages. Insuring drought in irrigated agriculture is particularly difficult. This is the reason why the United States is the only country where hydrological drought coverage is offered, albeit under very restrictive conditions to avoid adverse selection and moral hazard problems.

The main objective of this thesis is to carry out a study of a hydrological drought insurance for irrigated crops. Such a type of insurance should be effective in reducing risk exposure, easy to implement, complementary to water markets, and easy to adapt to crop insurance laws. The proposed insurance is a Hydrological Drought Index Insurance (HDII) which indemnifies the insured farmer based on the value of a selected drought index (DI). HDII protects water users from economic losses or increased costs due to water shortages and has been positively evaluated by an expert panel (Chapter 3).

Beyond the HDII literature, this thesis delves into a few key aspects relative to its development and implementation, such as DI selection and validation, and unitary indemnity estimation. This thesis also deals with the fact that water supply interruptions might be forecasted in inertial systems (in which reservoir capacity is large relative to annual inflows and water demands) when purchasing the insurance contract. This could generate intertemporal adverse selection, which is important to be considered when designing the HDII.

Chapter 3 provides the methodology to design an HDII in a non-inertial water supply system (in which water shortages might not be predicted before the crop season). Water value methods are used in this chapter to estimate the unitary indemnity, based on the added value of water of the region and linked to crop production. Unitary indemnity varies depending on the water allocated to irrigation, since the marginal value of water increases with its scarcity. Chapters 4 and 5 provide the methodology to design an HDII in an inertial system. Different schemes are proposed to deal with intertemporal adverse selection. Methodologies presented are applied to three case studies: Riegos de Bardenas in Spain (Chapter 3), El Viar Irrigation District in Spain (Chapter 4), and Central Valley in California in the United States (Chapter 5).

DI is based on hydrological variables. As a novelty, it can be based on institutional rules that determine water distribution between users. DI validation is based on basis risk assessment. Basis risk is the major obstacle for the use of index-based insurance since it implies that the 
indemnity received may not necessarily correspond to the actual losses incurred by the insurance policy holder.

To deal with intertemporal adverse selection, several alternative designs are proposed: variable premium design, variable deductible design, and early bird design. Variable premium is based on water availability forecasts when purchasing the insurance. Premium rates range from $8 \%$ to $24 \%$ over the liability in the case study presented in Chapter 5 and from $0 \%$ to $41 \%$ over the liability in the case study presented in Chapter 4. A multiyear contract is proposed to reduce the premium rate differences. In the highest risk scenario, premium rates decrease from $41 \%$ to $26 \%$ for a 3-year contract. A variable deductible design is proposed in Chapter 5 at a constant premium rate. Finally, early bird design could be sold before any water availability forecast is made. In the analyzed case studies, constant premiums equal $13 \%$ and $14 \%$ over the liability for $100 \%$ coverage. It appears as the most effective in reducing risk exposure and the most suitable for high-inertial water supply systems. Premium rates for the early bird design are high compared to those calculated for the Riegos de Bardenas case study (non-inertial system), which vary between $0.4 \%$ and $1.8 \%$ over the liability. This shows that inertial-systems, which are pose greater difficulties for developing drought insurance, are also those more exposed to drought risk.

The hedging effectiveness of HDII is addressed in Chapters 3 and 5. Hedging effectiveness is analyzed comparing several loss scenarios with and without insurance. Different premium rate structures are compared: actuarially fair premium and different premium loads representing potential administrative and capital costs of the insurance company. Despite adding premium loads to the commercial premium, insurance schemes are seem to be effective in reducing risk exposure. The margin to load the premium rate reveals a market opportunity to insurance suppliers.

Although the research had to overcome problems associated with insufficient data, results suggest that the proposed insurance scheme can be adapted to different irrigated regions and could provide an effective means of reducing farmer vulnerability to water shortages. Future research efforts could examine the potential demand of HDII and the interaction between HDII and water markets. 


\section{Table of contents}

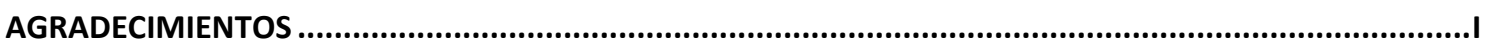

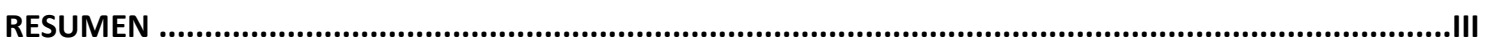

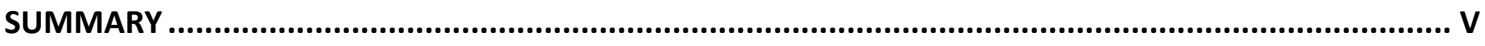

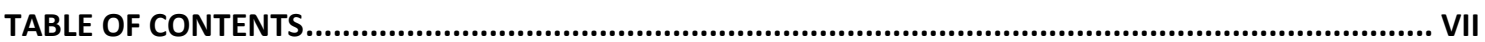

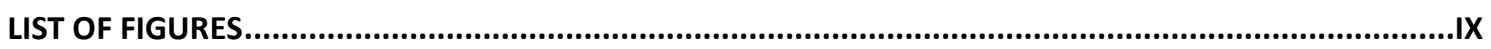

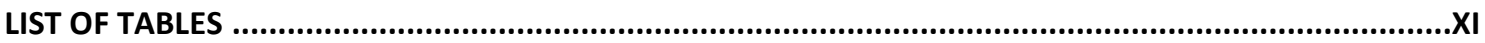

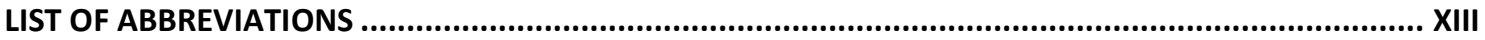

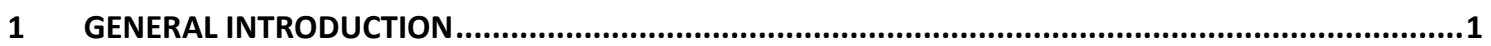

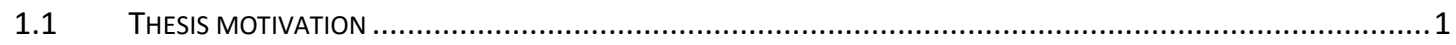

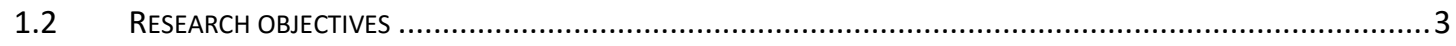

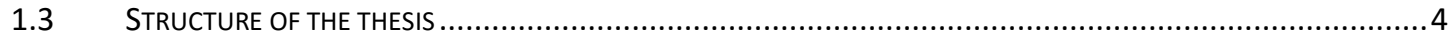

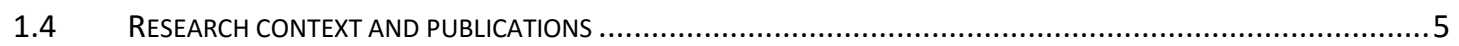

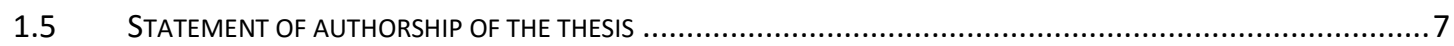

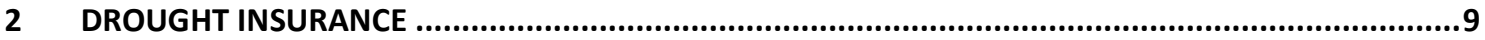

2.1 MAIN DIFFICULTIES AND CHALLENGES TO DEVELOP DROUGHT INSURANCE.........................................9

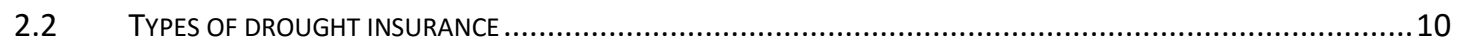

2.2.1 Traditional drought insurance with on-field los assessment ...........................................11

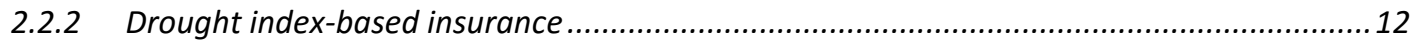

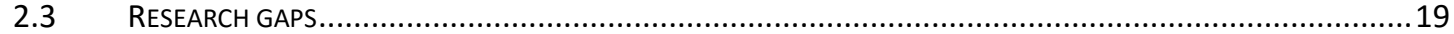

3 HYDROLOGICAL DROUGHT INDEX INSURANCE FOR IRRIGATION DISTRICTS IN SPAIN ................21

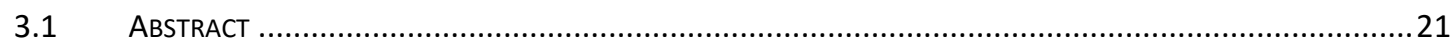

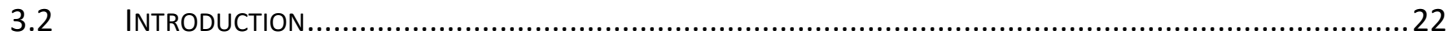

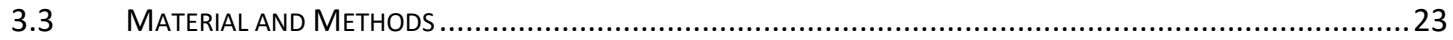

3.3.1 Selection of the insurance type: Expert panel ..................................................................23

3.3.2 Index insurance design, hedging effectiveness, and contract conditions ...........................26

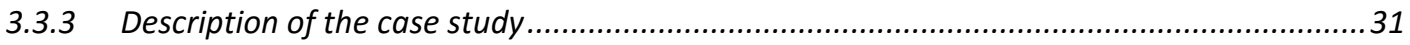

RESULTS

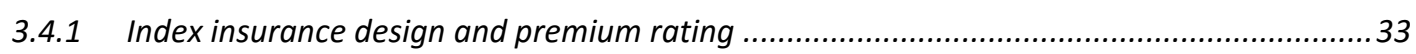

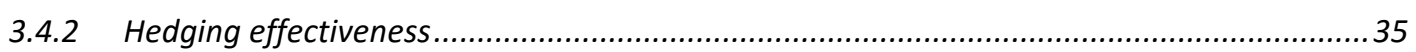

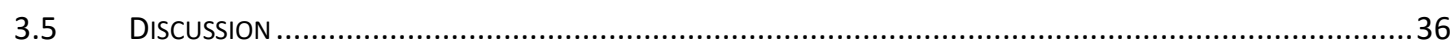


4 DEALING WITH INTERTEMPORAL ADVERSE SELECTION IN HYDROLOGICAL DROUGHT INDEX

INSURANCE

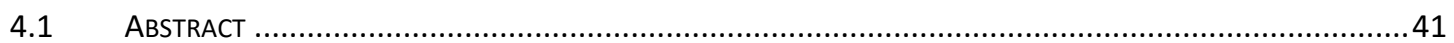

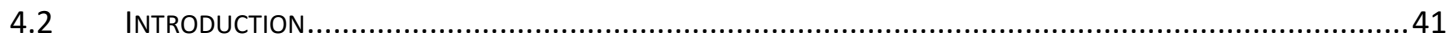

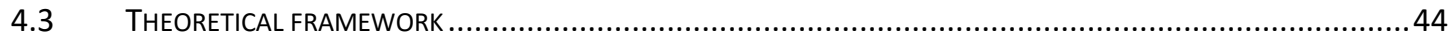

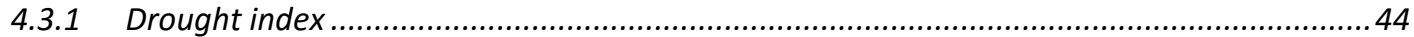

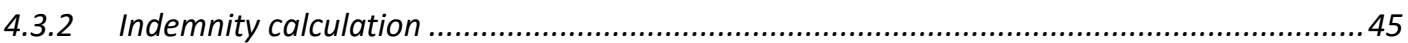

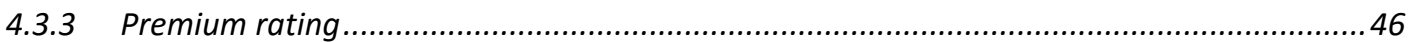

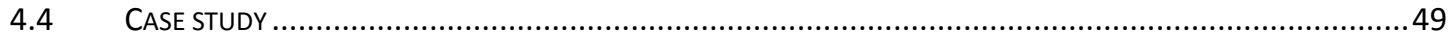

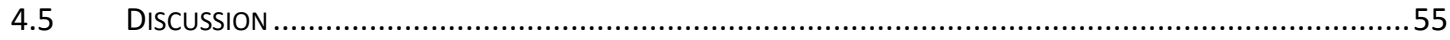

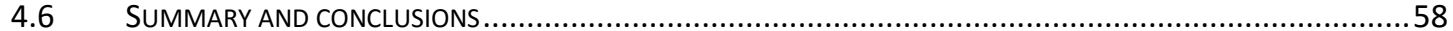

5 DROUGHT INDEX INSURANCE FOR THE CENTRAL VALLEY PROJECT IN CALIFORNIA ....................61

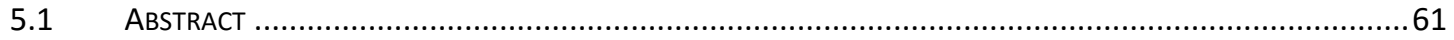

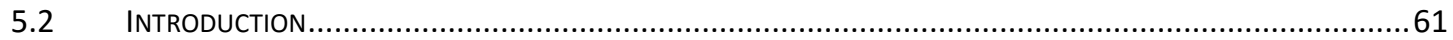

5.3 Water management In the Central Valley of California .........................................................6

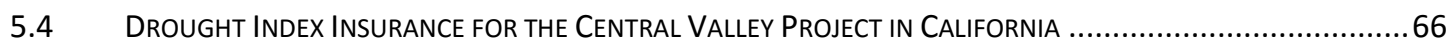

5.4.1 Potential for intertemporal adverse selection ........................................................67

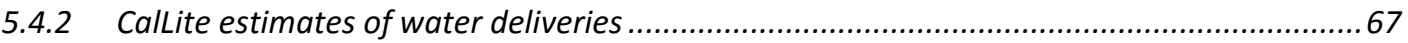

5.4.3 Design and rating of Sacramento Index insurance .....................................................69

5.4.4 Index insurance performance for Westlands Water District landowners and farmers ........ 74

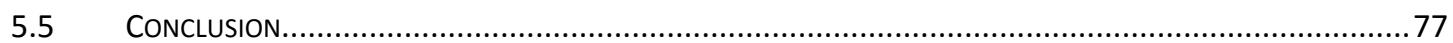

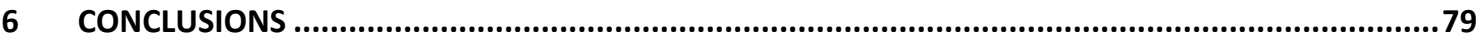

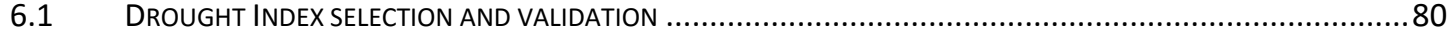

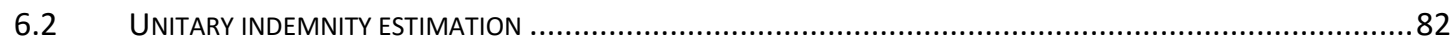

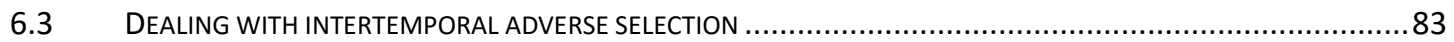

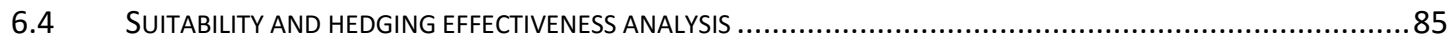

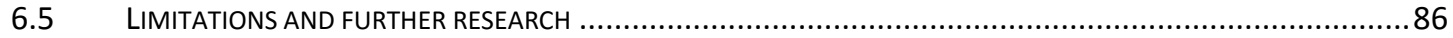

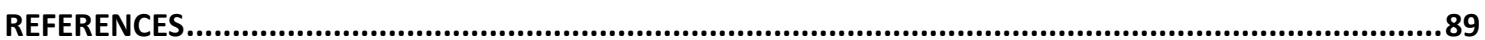

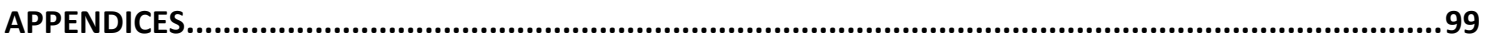

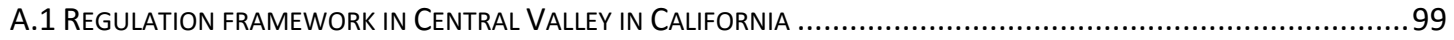

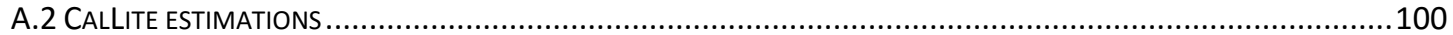

A.3 STOCHASTIC SIMULATION OF SACRAMENTO INDEX CONDITIONED ON THE VALUE OF THE SACRAMENTO INDEX IN PREVIOUS YEAR . 


\section{List of figures}

FIGURE 1.1. STRUCTURE OF THE THESIS. SOURCE: OWN ELABORATION

FigURE 2.1. PAYOFF DISTRIBUTION BY PERIL FOR THE PERIOD 1980-2014 IN SPAIN. OWN ELABORATION FROM AgROSEGURO . .9

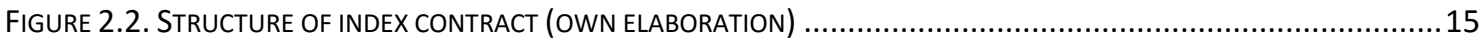

FIGURE 3.1. EXPERT PANEL DEVELOPMENT AND RESULtS. SOURCE: OWN ELABORATION. .............................................24

FigURE 3.2. WATER VALUE DEPENDING ON THE WATER ALLOCATION RECEIVED ON THE ID .......................................29

FiguRE 3.3. CROP SURFACE DISTRIBUTION, WATER ALLOTMENT AND NVAP ASSOCIATED TO SCENARIOS FOR THE CALCULATION

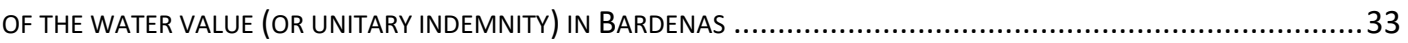

Figure 3.4. MOdel to eStimate WATER ALLOTMENTS BASED ON DROUGHT INDEX BASED ON 2000-2014 PERIOD ..........34

Figure 4.1. Drought Management Plan GUidelines Superimposed on actual Water allotments in El Viar IRRIGATION DISTRICT (1990-2012) 50

Figure 4.2. Correlation COEFFICIENT AND DEGREE OF SIGNIFICANCE BETWEEN APRIL RESERVES IN EL PINTADo (DSI APR) AND RESERVES IN EL PINTADO 1, 2, 3, UP TO 18 MONTHS IN ADVANCE (1953-2012) ...................................50

FIGURE 4.3. PREMIUM RATES IN PERCENTAGE OVER THE LIABILITY DEPENDING ON THE DROUGHT STATUS OF THE PRE-SEASON indeX (EMERgency, AleRt, PRe-Alert OR NoRmality) AND DEPENDING ON THE NUMBER OF YeARS OF THE INSURANCE POLICY (1953-2012)

Figure 4.4. COMPARISON BETWEEN ACTUAL WATER ALLOTMENTS IN EL VIAR AND WATER ALLOTMENTS ESTIMATED FROM

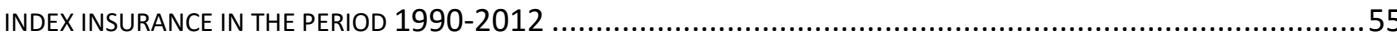

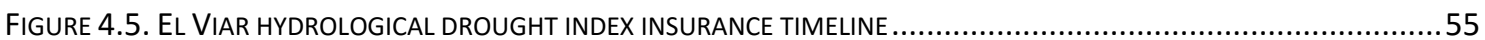

Figure 5.1. GEOgRAPHIC EXTENT AND GENERAL LOCATION OF SWP AND CVP FACILITIES IN CENTRAL VAlley IN CALIFORNIA. SOURCe: California Department of Water Resources And United States Bureau of ReClamation (2014)62

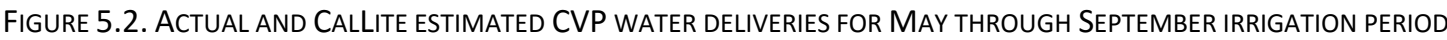
68

Figure 5.3. Timeline for Proposed Central Valley ProjeCt INDEX InSURANCE designS .....................................72

FIGURE 5.4. RELATIONSHIP BETWEEN SACRAMENTO INDEX AND (LEFT) GROUNDWATER PUMPED IN ACRE-FEET (AF) OR (RIGHT) WATER TABlE ElEVATION IN FEet (FT), WeStLANDS WATER DistRICT, 1974-2013 .............................75

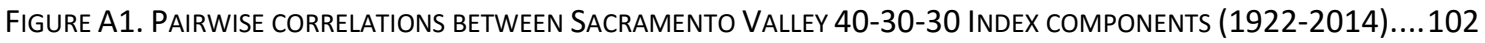





\section{List of tables}

TABLE 2.1. TYPES OF DROUGHT INSURANCE AND EXAMPLES OF DROUGHT INSURANCE IMPLEMENTED. SOURCE: OWN ELABORATION

TABLE 2.2.TYPES OF DROUGHT INDICATORS, EXAMPLES, VARIABLES USED, AND APPLICATIONS...................................14

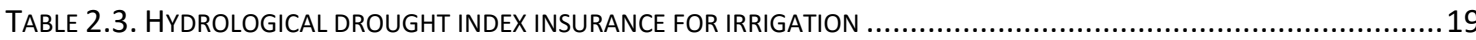

TABle 3.1. AVERAge Indemnities, GuARANTEEd WATER AlLOTMENT (GWA), LIABILITY, PREMIUM RATES AND BASIS RISK FOR HDDI IN BARDENAS, FOR AN INSURANCE SCHEME WITHOUT FRANCHISE DEDUCTIBLE (NFD) AND AN INSURANCE SCHEME WITH A FRANCHISE DEDUCTIBLE (FD)

TABLE 3.2. HedgING EFFECTIVENESS OF THE INSURANCE SCHEMES CONSIDERING 2000-2014 PERIOD 36

TABLE 4.1. RESIDUAL WATER VALUE PER CROP IN GUADALQUIVIR RIVER BASIN (2005) AND 5-YEAR-AVERAGE CROP SURFACE (2008-2012) IN EL VIAR IRRIGATION DISTRICT (VID).

TABLE 4.2. INDEX INSURANCE LIABILITY (IN $\mathrm{m}^{3} /$ HA AND IN €/HA/YEAR) AND PREMIUM RATING IN EL VIAR WITH A FRANCHISE DEDUCTIBLE OF 30\% FOR A 1-YEAR POLICY AND FOR A 3-YEAR POLICY (IN \% OVER THE LIABILITY AND IN €/HA/YEAR) DEPENDING ON THE TYPE OF CONTRACT: USING A PRE-SEASON INDEX CONTRACT OR AN EARLY-BIRD CONTRACT. PRESEASON INDEX CONTRACT PREMIUM RATE VARIES DEPENDING ON THE DROUGHT STATUS WHEN BUYING THE INSURANCE (Normality / Pre-alert / Alert / Emergency). Premium Rates are Calculated as the eXPeCted indemnity in THE PERIOD 1953-2012

TABLE 4.3. BASIS RISK (1990-2012) DIVIDED IN BASIS LOSS AND BASIS GAIN IN EL VIAR EXPRESSED IN PERCENTAGE TERMS OF TOTAL LIABILITY. TOTAL BASIS RISK IS DISAGGREGATED IN INSTITUTIONAL RISK, AND IN BASIS RISK FROM USING AUXI

TABle 5.1. SACRAmento VAlley 40-30-30 Index (SACRAmento IndeX) WATER YeAR Hydrologic Classifications...66 TABLE 5.2. DISTRIBUTIONS FITTED TO THE COMPONENTS OF THE SACRAMENTO INDEX IN THE PERIOD 1922-2014 AND SACRAMENTO INDEX CONDITIONAL DISTRIBUTIONS FOR A GIVEN VALUE T WITH SACRAMENTO INDEX IN YEAR T-1 EQUAL TO $2,4,6,8$, AND 10

TABLE 5.3. PREMIUM RATES FOR THE EARLY BIRD CONTRACT DESIGN CONSIDERING DIFFERENT SACRAMENTO INDEX THRESHOLdS. PREMIUM RATES ARE CALCULATED FROM HISTORICAL DATA (1922-2014) AND MONTECARLO SIMULATION

TABLE 5.4. HEDGING EFFECTIVENESS OF THE INDEX INSURANCE SCHEMES (UPPER THRESHOLD U=7.8) PROPOSED IN WESTLANDS WATER DISTRICT USING A LOSS FUNCTION BASED ON ANNUAL CASH RENT LOSSES (IN MILLION \$)

TABLE 5.5. HEDGING EFFECTIVENESS OF THE INDEX INSURANCE SCHEMES (UPPER THRESHOLD U=7.8) PROPOSED IN WESTLANDS WATER DISTRICT USING A LOSS FUNCTION BASED ON GROUNDWATER PUMPING COSTS (IN MILLION \$) .. 77

TABLE A1. SUMMARY STATISTICS FROM OCT-MAR DISTRIBUTION FITTING. 101

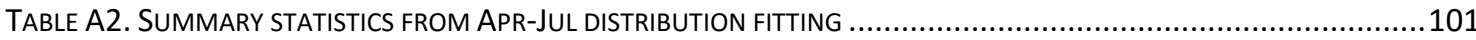

TABLE A3. SUMMARY STATISTICS FROM LAGGED SACRAMENTO INDEX DISTRIBUTION FITTING..................................102

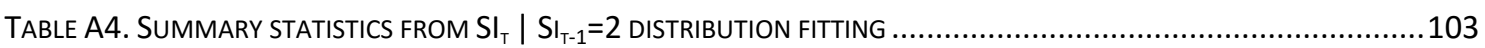

TABLE A5. SUMMARY STATISTICS FROM $\mathrm{SI}_{\mathrm{T}} \mid \mathrm{SI}_{\mathrm{T}-1}=4$ DISTRIBUTION FITTING 103 
TABLE A6. SUMMARY STATISTICS FROM SI $\mathrm{T}_{\mathrm{T}} \mathrm{SI}_{\mathrm{T}-1}=6$ DISTRIBUTION FITTING 103

TABLE A7. SUMMARY STATISTICS FROM SI $\mid \mathrm{SI}_{\mathrm{T}-1}=8$ DISTRIBUTION FITTING .....

TABLE A8. SUMMARY STATISTICS FROM $\mathrm{SI}_{\mathrm{T}} \mid \mathrm{SI}_{\mathrm{T}-1}=10$ DISTRIBUTION FITTING . 104 


\section{List of abbreviations}

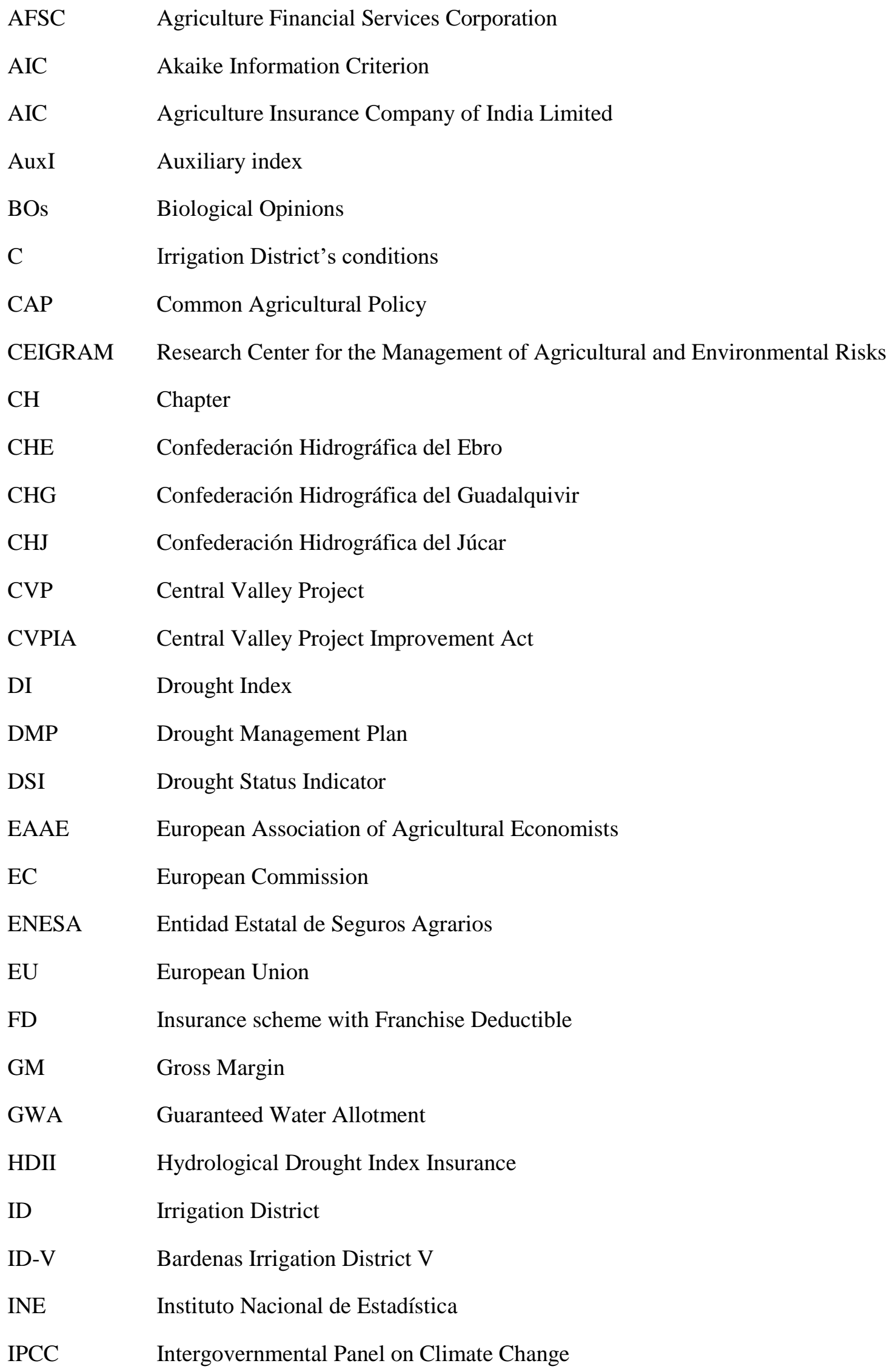


IRMI International Risk Management Institute

IS Índice de Sequía Hidrológica

K-S Kolmogorov-Smirnov

MAGRAMA Ministerio de Agricultura, Alimentación y Medio Ambiente

MLE Maximum likelihood estimation

MPCI Multi Peril Crop Insurance

MRSL Mean Root Square Loss

NDMC National Drought Mitigation Center

NDVI Normalized Difference Vegetation Index

NFD Insurance scheme without Franchise Deductible

NVAP Net Value of Agricultural Production

OECD Organization for Economic Co-operation and Development

PSI Pre-Season Index

RDI Rainfall Distribution Index

RMA Risk Management Agency

SCIS Spanish Crop Insurance System

SF $\quad$ Sowing Failure

SWP State Water Project

SWRCB State Water Resources Control Board

TAF Thousand acre-feet

US United States

USBR United States Bureau of Reclamation

USDA United States Department of Agriculture

VID El Viar Irrigation District

WWD Westlands Water District

$\gamma$

Franchise deductible 


\section{GENERAL INTRODUCTION}

\subsection{Thesis motivation}

Drought is a complex natural hazard that impacts ecosystems and society (Van Loon 2015). Estimates of drought impacts in recent years indicate that drought-related economic losses are becoming more severe (Stahl et al. 2012). Droughts do not only affect rainfed agriculture, they also affect the availability of water for irrigation. A meteorological drought is an anomaly defined by a prolonged period of low precipitations, usually affecting rainfed agriculture in large extensions of land. But when meteorological drought results in reduced water levels in streams, rivers, lakes, and reservoirs, then a hydrological drought sets in affecting water availability for irrigation (and for other uses).

Many water supply systems are currently under pressure. During the past decades human water use has more than doubled, while available freshwater resources are finite (Wada et al. 2011). Environmental policies, aiming to protect endangered species, pose more restrictions to irrigation water, intensifying water shortage problems for irrigated agriculture (Buchholz and Musshoff 2014; Johansson et al. 2002). Besides, climate change projections suggest that droughts will intensify in the $21^{\text {st }}$ century in southern Europe and the Mediterranean region, central Europe, central North America, central America and Mexico, northeast Brazil, and southern Africa (IPCC 2014). Multi-model experiments show that climate change is likely to exacerbate regional and global water scarcity considerably (Schewe et al. 2014), as well as the global severity of hydrological droughts (Prudhomme et al. 2014). Milly et al. (2005) project a 10-30\% decrease in runoff in southern Africa, southern Europe, the Middle East and midlatitude western North America by the year 2050.

Spain and California are examples of regions in which rainfed agriculture is exposed to significant rainfall variability, and irrigated agriculture highly vulnerable to water shortages. In Spain, irrigated land covers $13 \%$ of the useful agricultural surface, contributing to $50 \%$ of the total agricultural production value (INE 2012). The recurrent drought episodes affecting Spain (Curiel 2012) cause important economic losses (e.g. 3.5-4 billion $€$ in the Guadalquivir River Basin in 1993-1995 reported by Iglesias et al. (2007), 1.8 billion $€$ during the 1990-1995 in Spain reported by EC (2007b), 1.7 billion $€$ during the 1990-1995 in Andalusia reported by MAGRAMA (2008), 418 mill $€$ in the Ebro River Basin in 2005 estimated by Pérez y Pérez and Barreiro-Hurlé (2009). In spite of this, irrigated surface is still increasing. In the period 20042014, irrigated surface increased in average 1\% per year (MAGRAMA 2014b), but total water consumption decreased in average also $1 \%$ (INE 2015). 
California ranks first among US states in terms of farm-level sales. The availability of irrigation water has been a major factor in the development of California's agricultural production (Johnson and Cody 2015). Farmers have access to a wide portfolio of water sources, including water transfers, and surface storage, thanks to an extensive network of interconnected reservoirs, rivers, and aqueducts. Another important water source is groundwater, constituting on average about a third of statewide water use. Two important tools for modern water management in California are water marketing and the related practice of groundwater banking (Hanak and Stryjewski 2012). Water marketing has grown significantly in California over the past three decades, but it only represents 3\% of total water use (Hanak and Stryjewski 2012). Overexploitation of groundwater resources prompted the State legislature to enact a law of groundwater in California. Despite the continuous efforts to increase efficiency and water reliability, California remains vulnerable to water scarcity problems. For the past three years, California has experienced the most severe drought conditions in the last century (Griffin and Anchukaitis 2014), cutting back water deliveries due to drought and environmental factors and causing the loss of billions of dollars and thousands of seasonal and part-time jobs (Howitt et al. 2014).

The examples of Spain and California highlight the relevance in protecting farmers against drought risks. In order to cope with drought risks in agriculture, crop insurance, subsidized drought assistance, and water trading are some of the adaptation tools suggested by the IPCC (IPCC 2014). Crop insurance, as an adaptation tool against climate change, was already proposed by the European Commission (EC 2007a, see p.11) "Insurance sector could develop new insurance products for reducing risks and vulnerability before disasters strike. Insurance premiums anticipating climatic changes could provide incentives for private adaptation actions."

Agricultural insurance is one of the best tools that farmers can be offered to manage risks that are too large to manage on their own (World Bank 2011). Agricultural insurance can monetize the expected increase in the vulnerability of the agricultural sector and enables the producer to transfer his uncertainty to third parties, thus reducing the variability and risk associated with the loss of income (Pérez Blanco et al. 2011).

To protect rainfed crops against drought there are different insurance schemes available in numerous countries (Chapter 2). However, insurance schemes to protect irrigated crops against drought are unavailable in most countries. This is most likely due to the difficulty that entails insuring drought in irrigated crops (i.e. risk of intertemporal adverse selection, high moral hazard) (see section 2.1). Only in the United States this coverage is offered under the Multi Peril Crop Insurance (MPCI) program (RMA-Topeka 2015). Insurance policies involving on-field loss adjustment to evaluate losses (such as MPCI) involve a high moral hazard risk, which 
intensifies due to the nature of the risk covered. Other option to protect irrigated crops against drought that is proposed in research papers is index insurance (Zeuli and Skees 2005; Leiva and Skees 2008). With index insurance, moral hazard decreases, but still there is the risk of intertemporal adverse selection that needs to be addressed. Besides, index insurance needs to harmonize to national crop insurance laws and indemnities should be close to actual loss suffered by the farmer.

\subsection{Research objectives}

The main objective of this thesis is to propose and develop an insurance tool to help irrigators manage the risk of hydrological drought. With this objective in mind, the first question that arises is:

1. To protect irrigated crops against drought, what is the more suitable insurance scheme?

To answer this question, the Spanish framework is taken as reference, and different insurance options were suggested to an expert panel, forming part of the empirical foundation of the thesis (Chapter 3). The expert panel suggested that a Hydrological drought index insurance (HDII) is the best option to ensure irrigated crops in Spain against water shortages.

In consequence this thesis focuses on a Hydrological drought index insurance, and intends to delve into some concepts that have been overlooked in the literature. It also attempts to evaluate its success in reducing farmers' risk exposure in the case studies analyzed, in Spain and in California:

2. What drought index can be used as a proxy for water availability?

3. How to estimate the indemnity to be paid to farmers?

4. In water supply systems in which water availability for irrigation can be forecasted when purchasing the insurance policy, a risk of intertemporal adverse selection arises. How to avoid intertemporal adverse selection?

5. Is HDII effective in reducing risk exposure in each case study analyzed? 


\subsection{Structure of the thesis}

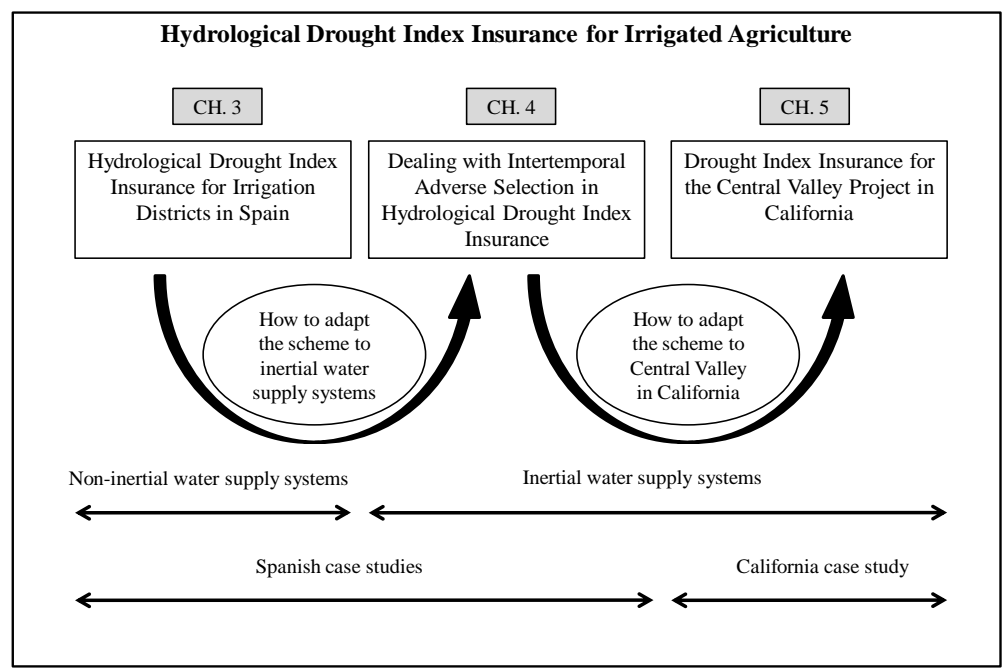

Figure 1.1. Structure of the thesis. Source: own elaboration

This thesis is structured in six chapters. Chapter 1: General introduction, sets the thesis motivation, the objectives and the research framework. Chapter 2: Drought insurance, reviews the main difficulties and challenges that drought insurance poses to the insurance developers and presents the different types of drought insurance in both rainfed systems and irrigated systems that are implemented or in study, with special attention to weather index insurance. Chapters 3, 4 and 5 consist of three related studies containing the original contribution of the thesis (see Figure 1.1). Chapter 3: Hydrological drought index insurance for irrigation districts in Spain, aims to propose an insurance tool to help irrigators manage the risk of water scarcity in the framework of the Spanish Crop Insurance System (SCIS). A Hydrological Drought Index Insurance (HDII) addressed to Irrigation Districts (ID) is proposed. A Spanish case study in the Ebro Basin illustrates the scheme. Its weaknesses and strengths are discussed. The insurance scheme is designed for water supply systems in which water shortages might not be predicted before the crop season (i.e. non-inertial water supply systems). The need of alternative schemes that take into account that water shortages might be predicted (i.e. inertial water supply systems) gives rise to Chapter 4: Dealing with intertemporal adverse selection in hydrological drought index insurance. This chapter presents several index insurance schemes aiming to avoid the intertemporal adverse selection. To illustrate the different schemes a case study showing inertial behavior is selected in the Guadalquivir Basin. Chapter 5: Drought index insurance for the Central Valley Project in California adapts the insurance scheme to another region suffering from severe hydrological drought episodes. The case study presents inertial behavior. Therefore 
the insurance schemes presented in Chapter 4 are implemented and a new insurance scheme is proposed. Last, Chapter 6: Conclusions, presents the main conclusions obtained in this doctoral research.

\subsection{Research context and publications}

This thesis is framed within the Research project Hydrological drought insurance for irrigation: an adaptation tool for climate change (no. AGL2010-17634), financed by the National Research, Development and Innovation Plan, Office of the State Secretariat for Research, Development and Innovation, Ministry of Economy and Competitiveness, Spain. It was carried out from January 2011- June 2014 at the CEIGRAM (Research Center for the Management of Agricultural and Environmental Risks, a Joint Research Center of the Technical University of Madrid) and was coordinated by Dr. Maria Bielza (Technical University of Madrid), in which my other supervisor, Professor Alberto Garrido, also participated. Within this project, I received a grant from the Ministry of Economy and Competitiveness to obtain my Master and $\mathrm{PhD}$ degree, from September 2011 to September 2015.

The project's main objective was to create the basis for the development of hydrological insurance as a means of adaptation to drought events and to the lack of reservoir water, in a climate change context.

As part of my training program, I could enjoy two research stays abroad in two different international universities (sponsored the Ministry of Economy and Competitiveness) aiming to enrich the research and provide support in specific thematic areas. First, a four-month stay (August 2012 - December 2012) was developed at the Department of Civil and Environmental Engineering at the University of Catania, where research work was conducted in Water Resources Group under the supervision of Dr. Antonino Cancelliere and Dr. Vincenzo Nicolosi. A second four-month stay (August 2014 - December 2014) took place at the Department of Agricultural Economics, in Mississippi State University. My work there was coordinated by Professor Dr. Barry Barnett and Professor Dr. Keith Coble. Each stay allowed me to gain experience and knowledge in different fields. The first stay focused on my knowledge in water and drought management, while the second stay contributed to my knowledge in crop insurance, particularly in index insurance.

From my participation in the project and from these two research stays, I wrote my Master thesis, I presented oral communications to international congress and I wrote research papers 
that are published or under review in different Scientific Journals. All contributions are listed below by chronological order:

- Bielza M, Maestro T, Algarra A, Garrido A (2012) Analysis of the impact of water shortage on irrigated fruit yields in Spain. Oral presentation at the European Geosciences Union (EGU) General Assembly, 22-27 April 2012, Vienna, Austria http://adsabs.harvard.edu/abs/2012EGUGA..1414106B

- Maestro T (2012) Analysis of the impact of water shortage on irrigated agriculture in Spain. Master thesis in order to obtain the Master degree in 'Agricultural, Food and Natural Resource Economics' by the Technical University of Madrid (2012). Directed by Professor Dr. Alberto Garrido and Dr. María Bielza. Mark: 8/10

- Maestro T, Nicolosi V, Cancelliere A, Bielza M (2013a) Probabilistic analysis of water availability for agriculture and associated crop net margins, Oral presentation at the 5th EAAE PhD Workshop, 29-31 May 2013, Leuven, Belgium

- Maestro T, Nicolosi V, Cancelliere A, Bielza M (2013b) Impacts of climate change, hydrological drought mitigation measures and irrigation demand on water supply system performance. Oral presentation at the 8th International Conference, European Water Resources Association, 26-29 June 2013, Porto, Portugal

- Maestro T, Nicolosi V, Cancelliere A, Bielza M. Impacts of climate change, hydrological drought mitigation measures and irrigation demand on water supply system performance. European Water (submitted)

- Maestro T, Bielza M, Garrido A (2016) Hydrological Drought index insurance for Irrigation Districts in Spain. Span J Agric Res 14(3): e01xx. doi: http://dx.doi.org/10.5424/sjar/2016143-8981

- Maestro T, Bielza M, Garrido A. Dealing with intertemporal adverse selection in hydrological drought index insurance. Water Resources and Economics (submitted)

- Maestro T, Barnett B, Coble K, Garrido A, Bielza M (2016) Drought Index Insurance for the Central Valley Project in California. Applied Economics Perspectives and Policy. doi: 10.1093/aepp/ppw013

During the research, we attempted to apply the Index insurance design to the Genil-Cabra General Irrigation District, situated in the province of Córdoba. The methodology was not applicable because none of the drought indicators analyzed presented a good correlation with water allotments (all correlation coefficients being below 0.5 , with $\mathrm{p}$-values indicating that none of the correlations was significant). 
In the framework of the project I had the opportunity to participate in several meetings with ENESA, irrigation districts, and river basin agencies that provided me with different and enriching insights into the topic of this thesis.

The project's last deliverable was a seminar held in May 2014. The seminar aimed to present and to disseminate the main results obtained during the project. I had the opportunity of presenting to the stakeholders my proposal of a Hydrological Drought Index Insurance scheme to protect irrigators against water shortages. An expert panel was held to evaluate and judge the results of the project. Discussion during this seminar gave me new ideas and helped me to focus the objectives of my thesis.

\subsection{Statement of authorship of the thesis}

This thesis contains no material which has been accepted for a degree or diploma by the University or any other institution, except by way of background information and duly acknowledged in the thesis, and to the best of my knowledge and belief no material previously published or written by another person except where due acknowledgement is made in the text of the thesis, nor does the thesis contain any material that infringes copyright.

The following persons and institutions contributed to the publication of the work undertaken as part of this thesis:

- Teresa Maestro, Technical University of Madrid: Candidate

- María Bielza, Technical University of Madrid: Author 1

- Alberto Garrido, Technical University of Madrid: Author 2

- Barry Barnett, Mississippi State University: Author 3

- Keith Coble, Mississippi State University: Author 4

Author details and their roles:

\section{Paper 1, Hydrological Drought Index Insurance for Irrigation Districts in Spain, located in Chapter 3.}

Candidate was the primary author. Author 1 and author 2 contributed to the idea. Expert panel was defined and organized by author 1 and author 2. Candidate and author 1 collected the data. Candidate performed the quantitative analysis, and interpreted the results. Authors 1 and 2 revised the manuscript, polished language and presentation, and performed a couple of revisions. 
Paper 2, Dealing with Intertemporal Adverse Selection in Hydrological Drought Index Insurance, located in Chapter 4.

Candidate was the primary author. Author 1 and author 2 contributed to the idea and its formalization. Candidate and author 1 collected the data. Candidate performed the simulations, quantitative analysis, and interpreted the results. Authors 1 and 2 revised the manuscript, polished language and presentation, and performed a couple of revisions.

Paper 3, Drought Index Insurance for the Central Valley in California, located in Chapter 5.

Candidate was the primary author. Author 3 and author 4 contributed to the idea and its formalization. Candidate collected the data, performed the simulations, and the quantitative analysis. Author 3 contributed significantly to the discussion and presentation. Author 3, author 4, author 2, and author 1 assisted with refinement. 


\section{DROUGHT INSURANCE}

The following sections provide a description of the main difficulties and challenges that drought insurance poses to the insurance developers, as well as the different types of drought insurance in both rainfed systems and irrigated systems that are implemented or in process of being developed. Weather index insurance is of particular importance for protecting irrigated crops against drought.

\subsection{Main difficulties and challenges to develop drought insurance}

Agricultural insurance stands among the most difficult insurance policies to develop. (1) Spatially correlated risk, (2) moral hazard, (3) adverse selection, and (4) high administrative costs are all important reasons why agricultural insurance markets may fail to take off (World Bank 2005).

Drought is a phenomenon particularly difficult to insure. It is the third risk in importance after hail and frost in the Spanish agricultural systems (Agroseguro 2015b) (see Figure 2.1). Its effects are prolonged in time and can be extended to more than one growing season. It may contribute to the occurrence of other problems or aggravate them (i.e. weakening plants and making them more susceptible to diseases). Besides, drought can be predicted in advance in some regions, leading to intertemporal adverse selection. Intertemporal adverse selection comes from the fact that pre-season weather information can influence crop insurance decisions (Carriquiry and Osgood 2012), as farmers could use this information to purchase insurance only in years with enhanced drought risk and probability of payout (Luo et al. 1994).

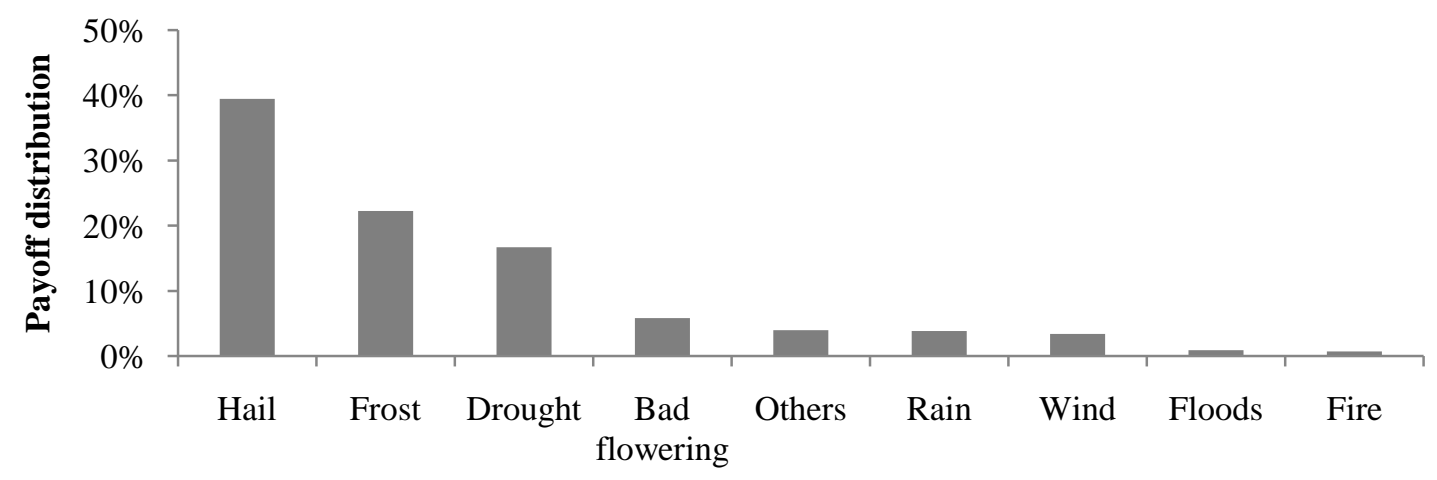

Figure 2.1. Payoff distribution by peril for the period 1980-2014 in Spain. Own elaboration from Agroseguro (2015b) 
The probability and severity of droughts can also be influenced by climate change. Climate change introduces a major factor of uncertainty in drought risks (Bielza et al. 2008). Increasing drought risk resulting from climate change affects the price of insurance in two ways. First, ambiguity and catastrophe loads increase because uncertainty associated with future climate change impacts leads insurers to plan for the worst likely scenario when establishing these loads. Historical return periods may not be valid since they might underestimate the likelihood of agricultural losses in the future. Second, increasing drought risk changes the pure risk (Collier et al. 2009). Consequently, insurance parameters have to be adjusted over time to effectively hedge future weather risk (Kapphan et al. 2012).

Protecting irrigated crops against drought (that causes irrigation water shortages) is even more challenging. This is due to the fact that there is a high uncertainty that stems from institutional decisions about water availability. Besides, moral hazard increases due to the water management and crop decisions at the farm, and farmers can have access to a wide portfolio of water resources.

\subsection{Types of drought insurance}

Drought insurance can be classified in different groups, depending on the way the loss

adjustment is performed: traditional crop insurance with on-field loss assessment or index based insurance; and depending on the crops insured: rainfed or irrigated crops. In traditional insurance, the damage is measured by loss adjusters that visit the damaged crops, whereas index insurance indemnifies the insured farmer based on the observed value of a specified index. Ideally, an index is a random variable that is objectively observable, reliably measurable, and highly correlated with the losses of the insuree, and additionally cannot be influenced by the actions of the insuree (Miranda and Farrin 2012).

In Table 2.1 some examples of drought insurance implemented are gathered. Whereas the risk of drought in rainfed system is sufficiently managed (at least in developed countries), the risk of drought in irrigated systems is still insufficiently managed. 
Table 2.1. Types of drought insurance and examples of drought insurance implemented. Source: own elaboration

\begin{tabular}{llcc}
\hline & Rainfed Crops & Irrigated crops \\
\hline $\begin{array}{l}\text { Traditional } \\
\text { insurance }\end{array}$ & & $\begin{array}{l}\text { e.g. MPCI program in Spain, } \\
\text { Cyprus, Argentina, Chile, Peru, } \\
\text { United States. }\end{array}$ & $\begin{array}{c}\text { Only MPCI program in } \\
\text { the United States }\end{array}$ \\
\hline $\begin{array}{l}\text { Index- } \\
\text { based } \\
\text { insurance }\end{array}$ & Area-yield & e.g. United States, Sweden, \\
& Meteorological index & Canada, India, etc. & - \\
& $\begin{array}{c}\text { e.g. Rainfall index insurance in } \\
\text { Mexico and in India }\end{array}$ & $\begin{array}{c}\text { Vietnam (not offered } \\
\text { anymore) }\end{array}$ \\
& $\begin{array}{l}\text { Remote sensing index } \\
\text { Hydrological index }\end{array}$ & e.g. Canada, Spain, United States & - \\
\hline
\end{tabular}

Note: The examples shown here are not intended to offer a complete view of all possible formats.

\subsubsection{Traditional drought insurance with on-field los assessment}

The traditional insurance more common is the Multiple Peril Crop Insurance (MPCI). It typically provides covers against multiple perils, considering a variety of different causes of yield loss. For MPCI, administrative costs are particularly high due to the need for establishing expected yields, assessing actual yields, categorizing potential insured farmers into appropriate risk pools, and monitoring to make sure that insured farmers employ appropriate production inputs and practices (Coble and Barnett 2013).

There are numerous countries providing insurance for rainfed crops against drought under this type of policy: Spain (ENESA 2012), Cyprus (Tsiourtis 2005), Argentina (Oficina del Riesgo Agropecuario 2010), Chile (Magallanes 2015), Peru (La Positiva 2015), United States (RMA 2015).

MPCI for irrigated crops is to our knowledge only implemented in the United States. Farmers can insure only the acreage that would be fully irrigated considering the expected water availability at the beginning of the crop season (when insurance attaches). The expected water availability is based on water stored in reservoirs, soil moisture levels, snow pack storage levels (if applicable), and precipitation which would normally be received during the crop season. To be covered by MPCI, any failure in irrigation water supply must be due to a naturally occurring event. Decreased water allocations due to a diversion of water for environmental reasons, compact compliance, or other non-naturally occurring causes are not covered (RMA-Topeka 2015).

Although not yet commercially implemented, several researchers have proposed other insurance schemes covering water shortage risk. Traditional insurance, using crop production functions or crop simulation models to assess the economic impact of drought have been proposed in some irrigated regions of Spain (Pérez Blanco and Gómez Gómez 2013; Quiroga et al. 2011; Ruiz et al. 2013; Ruiz et al. 2015). 


\subsubsection{Drought index-based insurance}

Index insurance is uncommon in high-income countries, which are dominated by markets with high uptake of MPCI insurance (World Bank 2011). Index products are useful for systemic risk, and best suited for homogeneous areas (Bielza et al. 2008).

We can differentiate between area-yield (or revenue) index insurance, in which indemnities are paid based on a shortfall in area average yield (or revenue) (Coble and Barnett 2008; Miranda 1991; Skees et al. 1997), and weather index insurance (Barnett and Mahul 2007; Collier et al. 2009; Martin et al. 2001; Ritter et al. 2012; Skees 2010; Turvey 2001; Vedenov and Barnett 2004). Area-yield (or revenue) insurance is based on the yields that have historically been produced in a homogeneous geographical area. Therefore, if the zonal yields fall below a certain value, all the insured farmers in that area receive compensation, regardless of who has actually suffered losses or who has not (United States, Sweden, Canada and India, among others, offer this type of insurance). In weather index insurance, indemnities are paid based on realizations of a specific weather or hydrologic parameter.

Weather index insurance is similar to weather derivatives (Hess and Syroka 2005). The risk transfer characteristics and benefits are similar. However, the two of them differ in regulatory, accounting, tax, and legal issues. Besides, derivative products are not necessarily associated with any physical loss (World Bank 2011).

Advantages of index insurance in comparison to traditional schemes are (World Bank 2011):

- Reduced risk of adverse selection, because index instruments do not require insurers to classify potential purchasers according to their risk exposure. Weather index instruments can however, be susceptible to intertemporal adverse selection (Barnett et al. 2008).

- Reduced moral hazard, because farmers cannot influence the probability of claim. Besides, since farmers have incentives to continue to produce or to try to save their crops and livestock even in the face of bad weather events, index insurance should provide for a more efficient allocation of resources (World Bank 2005).

- Field loss assessment is eliminated, decreasing administrative costs.

- Reduced information requirements and bureaucracy, decreasing administrative costs.

- Transparency and facilitation of reinsurance, because it is based on independently measured weather events.

The selection of the index in which the insurance should be based has been widely discussed in the literature (Bielza et al. 2008; Leiva and Skees 2008; World Bank 2011). The two basic 
prerequisites of an appropriate index are: (1) high correlation with the potential loss, and (2) fulfillment of the quality standards of the insurance industry (observable and easily measured, objective, transparent, independently verifiable, reported in a timely manner, consistent over time, and experienced over a wide area, and not subject of manipulation).

There are different types of drought indicators depending on the variables on which they are based, which can be used as underlying indices in drought insurance. They are used for drought monitoring and drought management purposes (Estrela and Vargas 2012).

In Table 2.2, some examples of meteorological, agronomic, hydrologic, and remote sensing drought indicators are gathered, mentioning as well some of its applications in drought management and drought insurance.

Depending on the underlying index, we can then classify weather-based drought index insurance in meteorological drought index insurance, remote sensing drought index insurance, and hydrological drought index insurance (see Table 2.1).

A major obstacle for the use of index-based insurance in practice is basis risk (Vedenov and Barnett 2004; Woodard and Garcia 2008). Basis risk is the deviation between actual losses and insurance payoff. Basis risk reduces the hedging effectiveness of index insurance and lowers the willingness to pay for these instruments (Ritter et al. 2012). Due to the fact that index insurance indemnities are triggered, not by farm-level losses, but rather by the value of an independent measure (the index), a policyholder can experience a loss and yet receive no indemnity. Conversely, the policyholder may not experience a loss and yet receive an indemnity. The effectiveness of index insurance as a risk management tool depends on how positively correlated farm level losses are with the underlying index. 
Table 2.2.Types of drought indicators, examples, variables used, and applications ${ }^{1}$

\begin{tabular}{|c|c|c|c|}
\hline $\begin{array}{l}\text { Type of } \\
\text { indicator }\end{array}$ & $\begin{array}{l}\text { Name and } \\
\text { Reference }\end{array}$ & Based on & Application \\
\hline \multirow[t]{3}{*}{ Meteorological } & $\begin{array}{l}\text { Deciles (Gibbs } \\
\text { and Maher } \\
\text { 1967) }\end{array}$ & Rainfall & $\begin{array}{l}\text { Used for drought monitoring in Australia } \\
\text { (Australian Bureau of Meteorology 2015) }\end{array}$ \\
\hline & $\begin{array}{l}\text { Standardized } \\
\text { Precipitation } \\
\text { Index (McKee } \\
\text { and Doesken } \\
\text { 1993) }\end{array}$ & $\begin{array}{l}\text { Rainfall, } \\
\text { evapotranspiration, } \\
\text { temperature }\end{array}$ & $\begin{array}{l}\text { Used for drought monitoring in the USA } \\
\text { (NDMC 2015) }\end{array}$ \\
\hline & $\begin{array}{l}\text { Various } \\
\text { cumulative } \\
\text { precipitation } \\
\text { indices }\end{array}$ & Rainfall & $\begin{array}{l}\text { Used in India (AIC 2015) and in Canada } \\
\text { (AFSC 2015a; Agricorp 2015) as trigger for } \\
\text { drought insurance }\end{array}$ \\
\hline \multirow[t]{3}{*}{ Agronomic } & $\begin{array}{l}\text { Palmer Drought } \\
\text { Severity Index } \\
\text { (Palmer 1965) }\end{array}$ & $\begin{array}{l}\text { Rainfall, } \\
\text { evapotranspiration, } \\
\text { soil water content } \\
\text { and water balances }\end{array}$ & $\begin{array}{l}\text { Used for drought monitoring in the USA (US } \\
\text { Drought Portal 2015b) }\end{array}$ \\
\hline & $\begin{array}{l}\text { Crop Moisture } \\
\text { Index (Palmer } \\
\text { 1968) }\end{array}$ & $\begin{array}{l}\text { Rainfall, } \\
\text { evapotranspiration, } \\
\text { soil water content } \\
\text { and water balances }\end{array}$ & $\begin{array}{l}\text { Used for drought monitoring in the USA (US } \\
\text { Drought Portal 2015a) }\end{array}$ \\
\hline & $\begin{array}{l}\text { FCDD indexes } \\
\text { (Bielza et al. } \\
\text { 2008; Hartell et } \\
\text { al. 2006) }\end{array}$ & $\begin{array}{l}\text { Temperature, } \\
\text { humidity, } \\
\text { precipitation }\end{array}$ & $\begin{array}{l}\text { Used as a trigger in Weather Risk Transfer for } \\
\text { the Agroasemex Agricultural Portofolio } \\
\text { (Bielza et al. 2008; Hartell et al. 2006) }\end{array}$ \\
\hline \multirow[t]{2}{*}{ Hydrological } & $\begin{array}{l}\text { Status indicators } \\
\text { (CHJ 2007) }\end{array}$ & $\begin{array}{l}\text { Streamflow data, } \\
\text { reservoir volumes, } \\
\text { aquifers, and snow }\end{array}$ & $\begin{array}{l}\text { Drought Management Plans in Spain (Estrela } \\
\text { and Vargas 2012) }\end{array}$ \\
\hline & $\begin{array}{l}\text { Sacramento } \\
\text { Valley Index } \\
\text { (USBR 2008) }\end{array}$ & Streamflow data & $\begin{array}{l}\text { Used by the California Department of Water } \\
\text { Resources and the United States Bureau of } \\
\text { Reclamation (USBR 2008) }\end{array}$ \\
\hline $\begin{array}{l}\text { Remote } \\
\text { sensing }\end{array}$ & $\begin{array}{l}\text { Normalized } \\
\text { Difference } \\
\text { Vegetation } \\
\text { Index (NDVI) } \\
\text { (Rouse et al. } \\
\text { 1974) }\end{array}$ & Satellite images & $\begin{array}{l}\text { Used for the triggering of pasture insurance } \\
\text { against drought in Spain (Agroseguro 2015a) } \\
\text { and in Alberta (AFSC 2015b) }\end{array}$ \\
\hline
\end{tabular}

${ }^{1}$ For a more detailed list of drought indicators, readers may refer to Byun and Wilhite (1999); Heim (2002); Keyantash 
In addition to defining the index, the weather station from which the weather variables are taken to construct the index are measured and recorded, the buyer/seller information (names, crop, and surface insured), the premium, and the risk protection period of the contract, an index-based weather insurance contract must also include the following information (Hartell et al. 2006):

- Strike or trigger or upper threshold, which is the index level at which weather protection is triggered. The trigger that signals the payment due to crop loss is very important in the pricing of index insurance products and therefore it is desirable to obtain an optimal trigger for indication of crop loss (Choudhury et al. 2015). The strike determines the level of risk retention of the insuree, a trigger very close to the mean of the index indicates a low level of risk retention by the end user and a contract that will pay out with high probability (Hartell et al. 2006).

- Tick size, which is the financial compensation per unit index deviation above or below the trigger(s) and which converts the index outcome into a monetary amount (Ritter et al. 2012; World Bank 2011).

- Liability is the level of protection of the index insurance (Zeuli and Skees 2005). It corresponds to the maximum indemnity that an insuree may received (Miranda and Farrin 2012).

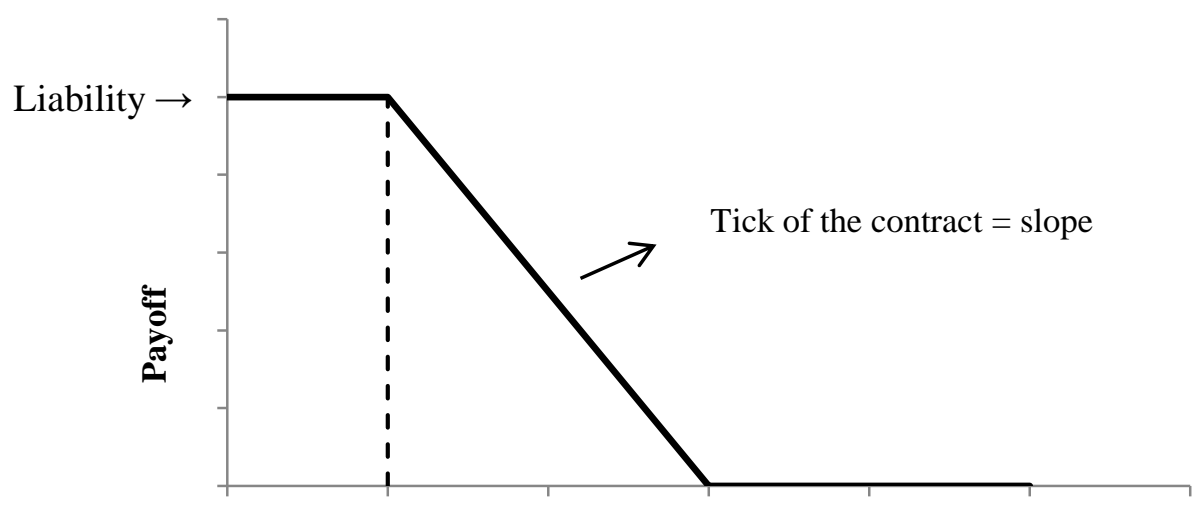

\section{Drought Index: Cummulative Rainfall}

Figure 2.2. Structure of index contract (own elaboration)

Index insurance usually follows the scheme shown in Figure 2.2, in which the variable used for the contract design is the cumulative rainfall. The policy pays zero if accumulated rainfall during the crop season exceeds the upper threshold, otherwise, the policy pays an indemnity (the tick) for each millimeter of rainfall deficiency relative to the strike, until the lower 
threshold is reached. If rainfall is below the lower threshold value, the policy pays a fixed, higher indemnity (Giné et al. 2007; Martin et al. 2001; Vedenov and Barnett 2004; World Bank 2011). Appropriate thresholds will then need to be set for each risk and each country (Hess and Syroka 2005).

Next sections provide some examples of drought index insurance implemented for rainfed and irrigated crops (see Table 2.1), and some research advances in designing drought index insurance (weather-based) for irrigated crops.

\subsubsection{Meteorological-based index insurance}

The use of meteorological-based index insurance to cover rainfed crops against drought is widespread among middle and lower-income countries. Mexico and India currently have the most developed rainfall index insurance programs. In both countries the products were first introduced in 2003 and focus primarily on rainfall deficiency (drought) (Barnett and Mahul 2007). In Mexico there is insurance to protect maize, corn, beans, sorghum and barley growers against catastrophic losses due to droughts and floods. This insurance is based on a rainfall index that sets two triggers (to signal a drought or a flooding). These trigger levels differ according to the crop, region and crop growth stages (i.e. sowing, flowering and harvesting) (Hazell et al. 2010).

Rainfall index insurance "Varsha Bima" in India covers anticipated yield losses on account of shortfall in the actual rainfall within a specific location and period. It provides for two options 'Sowing Failure (SF)' and 'Rainfall Distribution Index (RDI)'. The SF covers the risk of prevented / failed sowing, while RDI covers entire season's rainfall requirement with due respect to moisture requirement at critical stages of crop growth. Rainfall index is created by (i) giving weights to rainfall of critical periods and (ii) by capping for excess rainfall. "Varsha Bima" has been designed for popular and widely grown field crops like rice, bajra, maize, jowar, groundnut in the drought prone areas (AIC 2015).

Pilot projects have been started in several countries (mostly supported by the World Bank) including Thailand, Indonesia, Malawi, Kenya, and Nicaragua (World Bank 2011; IRI 2010).

Instead of covering yield losses, some insurance schemes protect against additional irrigation costs in a period of drought. From an economic point of view, a loss due to a shortfall in yields does not differ with a loss due to increased costs of irrigation (Mafoua and Turvey 2003). A rainfall-based drought index insurance scheme for individual coffee farmers in Vietnam, aimed to compensate for additional costs incurred during a period of drought. Generally, coffee is irrigated three times a year. In the event of drought, a fourth irrigation is needed. This insurance was studied by GlobalAgRisk (2009) and implemented by the Bao Minh Company at a 
premium rate of 10\% (Bao Minh 2015). However, the insurer has stopped offering drought insurance for coffee in Daklak due to losses (Mai and Hung 2013).

Although not yet implemented, several researchers have investigated the potential of meteorological based index insurance to cover irrigated crops against drought. Mafoua and Turvey (2003) provide a starting point for examining how a rainfall can be used to mitigate excessive irrigation costs for farmers. For that, they develop an economic model of irrigation cost insurance to illustrate the relationship between a weather variable (rainfall), crop yields, costs of irrigation and profits.

Zeuli and Skees (2005) also propose a financial product called cumulative Rainfall Insurance Contract in a New South Wales irrigation district in Australia, to manage water supply risk. For the implementation, historic rainfall levels need to be highly and positively correlated to historic reservoir water levels. The coverage level and liability is chosen by the insuree and are independent from the crops in the farm.

Thompson et al. (2009) analyze the potential for using a rainfall derivative to manage the annual risk associated with entering the crop year with less than a normal irrigation supply.

More recently, Buchholz and Musshoff (2014) investigate the potential of index-based weather insurance (with underlying precipitation and temperature indices), to cope with the economic disadvantages for farmers resulting from a reduction in water quotas and increased water prices.

\subsubsection{Remote sensing-based index insurance}

Remote sensing-based index insurance provides an inexpensive method of hedging against drought risk in rainfed crops: pasture, rangeland and large monocultures. Recent advances in satellite remote sensing technology now permit accurate measurements at particular spatial scales and spectral bandwidths that allow dynamic monitoring of environmental conditions such as vegetation cover. Remote sensing is a powerful tool for evaluating crop growing conditions and drought (Peters et al. 2002).

NDVI-based insurance programs currently exist in the Canada, Spain, and the United States (Turvey and Mclaurin 2012). In 2001 Alberta (Canada) launched a pilot project using satellite imagery to define an historical "benchmark" production and assess annual pasture production (Hartell et al. 2006; World Bank 2005). In Spain the product has been offered also since 2001 for extensive livestock farmers, specifically on the following species: cattle, sheep, horses, and goats. The insurance product is designed to cover the farmers experiencing more than 30 dry days (based on the average historical information on pasture) (Agroseguro 2015b). In the United 
States, there is an insurance based on vegetation indices since 2007 to cover Pasture, Rangeland, and Forage (RMA 2014).

Differences between payments and actual losses (i.e. basis risk) might decrease over the time, since improvements in this field are very quick so that imagery resolution increases regularly and new technologies could emerge in the near future (Leblois and Quirion 2010).

\subsubsection{Hydrological drought index insurance}

Although not commercially offered, several hydrological drought index insurance mechanisms have been proposed in the literature seeking to cover financial risks for water managers (Brown and Carriquiry 2007; Zeff and Characklis 2013) and offering covers for agricultural production (Leiva and Skees 2008). Brown and Carriquiry (2007) use seasonal inflows to develop an index insurance that compensates an urban water supplier for the increased costs associated with acquiring water from irrigators during dry periods via option contracts. Zeff and Characklis (2013) propose an index insurance based on streamflows and withdrawals from a multireservoir system that generally refills each year. They propose a contract that is purchased once per year at the beginning of the irrigation season, when reservoir levels are typically full. Leiva and Skees (2008) propose an index insurance scheme presenting two types of contracts, based on 12 or 18-month river flow accumulation in the whole Rio Mayo irrigation system in northwestern Mexico. Cumulated river flows are highly correlated to annual plantings. The insured district obtains an indemnity based on the district average expected income per ha, when the accumulation of reservoir inflows falls below a predetermined threshold.

Intertemporal adverse selection might occur in the presence of skillful contracts. In such cases, Brown and Carriquiry (2007) suggest that the contracts should be signed before forecasts were available or otherwise, insurees could adjust premiums in accordance with forecasts. However, none of them adapt the insurance scheme to deal with intertemporal adverse selection.

Table 2.3 include the main characteristics (risk covered, policy holder, index used, tick of the insurance, method for the premium calculation, duration of the contract, contract conditions and the study case analyzed) of the three index insurance schemes proposed in the literature. None of them have been implemented, but show potential to protect irrigators or water utilities against hydrological drought economic losses. 
Table 2.3. Hydrological drought index insurance for irrigation

\begin{tabular}{|c|c|c|c|}
\hline Insurance name: & $\begin{array}{l}\text { Third-party index } \\
\text { insurance contracts } \\
\text { (Zeff and Characklis } \\
\text { 2013) }\end{array}$ & $\begin{array}{l}\text { Irrigation insurance } \\
\text { (Leiva and Skees 2008) }\end{array}$ & $\begin{array}{l}\text { Reservoir index insurance } \\
\text { (linked to option contracts) } \\
\text { (Brown and Carriquiry 2007) }\end{array}$ \\
\hline Risk covered & $\begin{array}{l}\text { - Water utility financial } \\
\text { risks }\end{array}$ & $\begin{array}{l}\text { - Irrigation district } \\
\text { income variability }\end{array}$ & - Water utility financial risks \\
\hline Policy holder & - Water utility & - Irrigation district & - Urban water supplier \\
\hline Index & $\begin{array}{l}\text { - Streamflow index } \\
\text { (compared to withdrawals } \\
\text { form a reservoir) }\end{array}$ & $\begin{array}{l}\text { - Streamflow index } \\
\text { (linked to irrigated } \\
\text { plantings) }\end{array}$ & $\begin{array}{l}\text { - Streamflow index (inflows } \\
\text { to a reservoir) }\end{array}$ \\
\hline $\begin{array}{l}\text { Tick of the } \\
\text { insurance }\end{array}$ & $\begin{array}{l}\text { - } 1 \$ \text { contracts. Insured } \\
\text { could buy the number of } \\
\text { contracts desired }\end{array}$ & $\begin{array}{l}\text { - Based on ha-equivalent } \\
\text { income }\end{array}$ & - Based on water prices \\
\hline $\begin{array}{l}\text { Premium } \\
\text { calculation }\end{array}$ & $\begin{array}{l}\text { - Synthetic inflows and } \\
\text { Montecarlo simulation }\end{array}$ & $\begin{array}{l}\text { - Simulation model } \\
\text { taking into account } \\
\text { reservoir operation } \\
\text { policies }\end{array}$ & - Montecarlo simulation \\
\hline $\begin{array}{l}\text { Duration of } \\
\text { contract }\end{array}$ & - Annual & - 12-month or 18 -month & - Annual \\
\hline $\begin{array}{l}\text { Contract } \\
\text { conditions (if } \\
\text { mentioned) }\end{array}$ & $\begin{array}{l}\text { - Single purpose } \\
\text { reservoir. Reservoir refill } \\
\text { each year }\end{array}$ & - & $\begin{array}{l}\text { - Insurance contracts signed } \\
\text { before forecasts are available }\end{array}$ \\
\hline Study case & $\begin{array}{l}\text { - Durham water utility, } \\
\text { north Carolina, United } \\
\text { states }\end{array}$ & $\begin{array}{l}\text { - Rio Mayo irrigation } \\
\text { district }\end{array}$ & $\begin{array}{l}\text { - Water system in Metro } \\
\text { Manila, Philippines }\end{array}$ \\
\hline
\end{tabular}

\subsection{Research gaps}

Research gaps from previous works in drought insurance are summarized in the following paragraphs.

Whereas drought risk in rainfed crops is already insured in numerous countries, irrigated crops are mostly unprotected (just one country offers this coverage under a MPCI program).

Several index insurance schemes to protect irrigated crops against drought are proposed in the literature. However, they are not adapted to crop insurance laws, since the indemnity received by the farmer does not reflect actual losses in the field depending on the water deficit suffered. 
Third, the literature has not delved into issues related to adverse selection resulting from the fact that storage systems provide a supply buffer that conditions the probability of irrigation water supply interruptions.

Last and fourth, the literature has not evaluated the composition of basis risk, resulting from the use of drought indices. 


\section{HYDROLOGICAL DROUGHT INDEX INSURANCE FOR IRRIGATION DISTRICTS IN SPAIN}

This chapter aims to propose an insurance tool to help irrigators manage the risk of water scarcity in the framework of the Spanish Crop Insurance System (SCIS). A Hydrological Drought Index Insurance (HDII) addressed to Irrigation Districts (ID) is proposed. A Spanish case study in Ebro Basin illustrates the scheme. Its weaknesses and strengths are discussed. The insurance scheme is designed for water supply systems in which water shortages might not be predicted before the crop season (i.e. non-inertial water supply systems).

Publication: Maestro T, Bielza M, Garrido A (2016) Hydrological Drought index insurance for Irrigation Districts in Spain. Span J Agric Res 14(3): e01xx. doi: http://dx.doi.org/10.5424/sjar/2016143-8981

\subsection{Abstract}

Hydrological droughts are a major risk for irrigated agriculture in many regions of the world. The aim of this article is to propose an insurance tool to help irrigators manage the risk of water scarcity in the framework of the Spanish Crop Insurance System (SCIS). Only the United States Insurance System provides this type of coverage, but has very restrictive conditions. To determine the type of insurance scheme that better fits with the SCIS and to the Spanish irrigated agriculture, an expert panel was held with the participation of all stakeholders involved in crop insurance. Following the expert panel conclusions, an Hydrological Drought Index Insurance (HDII) addressed to Irrigation Districts (ID) is proposed. It would compensate water deficits suffered in the whole ID. We detail the conditions that the ID should fulfill to be eligible for HDII. HDII is applied to the Bardenas Irrigation District V (ID-V) in Spain, and the hedging effectiveness of the instrument is analyzed comparing ID-V's gross margins with and without the insurance contract. Results suggest that the proposed insurance scheme could provide an effective means of reducing farmers' vulnerability to water shortages and there is no major impediment for it to be included as a new line in the SCIS. This type of insurance can be generalized to any ID fulfilling the conditions mentioned in this paper. 


\subsection{Introduction}

Drought is one of the main environmental risks in Mediterranean Europe. Climate change predictions indicate that droughts will intensify in the $21^{\text {st }}$ century in the region (IPCC 2012). One of the main adaptation tools to climate change in arid zones is irrigation. Drought does not only affect rainfed agriculture; it also affects the availability of water for irrigation. Meteorological droughts predate hydrological droughts, reducing the availability of surface and groundwater sources, and giving rise to water shortages both for consumption uses and for environmental flows. Water scarcity in irrigated farming systems results in potentially greater economic losses than in rainfed systems, due to the higher investments being made on the farm.

To manage water scarcity, deficit irrigation has been studied and implemented, particularly to ligneous crops, showing satisfactory results (Ruiz-Sanchez et al. 2010). Water markets are commonly used in Australia, Chile and the United States under widely different regulatory frameworks, facilitating the reallocation of water resources among users, therefore allocating water to high-value uses and improving water use efficiency. At the European Union (EU) level, only Spain has developed a regulatory framework to permit water trading (Easter and Huang 2014; Rey et al. 2014). Insurance is also a means to manage water supply instability (Rey et al. 2015; Pérez Blanco and Gómez Gómez 2013).

The Spanish Crop Insurance System (SCIS) is one of the most advanced and widespread systems in the EU, serving as a benchmark for international comparisons of insurance systems (OECD 2011). Yet, irrigated agriculture is unprotected against losses due to the lack of water for irrigation. In Spain, irrigated land covers $13 \%$ of the useful agricultural surface, contributing to $50 \%$ of the total agricultural production value (INE 2012). In spite of the recurrent drought episodes that affect Spain (Estrela and Vargas 2012), irrigated surface is still increasing. In the period 2004-2014, irrigated surface increased on average 1\% per year (MAGRAMA 2014a). In consequence, there is an evident need for an insurance policy to cover the risk of water scarcity, as has already been demanded by the agricultural sector.

As far as we know, the only experience on drought insurance for irrigated agriculture is implemented in the United States. The Multiple Peril Crop Insurance program in the United States covers the unexpected failure of irrigation water supply. Irrigated yield losses are covered when water shortages are due to a naturally occurring event and cannot be foreseen at the time of the insurance take-up (prevented planting insurance is a possible alternative when a water shortage is expected). The insurance scheme has detailed provisions in order to avoid moral hazard. Besides, decreased water allocations due to a diversion of water for environmental reasons, selling water to municipalities, or other causes are not covered (RMA-Topeka 2015). 
Several researchers have proposed other insurance schemes covering water shortage risk. Traditional schemes, using crop production functions or crop simulation models to assess the economic impact of drought have been proposed in some irrigated regions of Spain (Quiroga et al. 2011; Pérez Blanco and Gómez Gómez 2013; Ruiz et al. 2013; Ruiz et al. 2015). Index insurance mechanisms have been proposed in the literature seeking to cover financial risks for water managers (Brown and Carriquiry 2007; Zeff and Charaklis 2013) and offering coverage for agricultural production (Zeuli and Skees 2005; Leiva and Skees 2008).

The aim of this article is to propose an insurance tool to protect irrigators against water scarcity in the framework of the SCIS. The tool would mitigate the economic cost of water shortages. The novelty of our approach, with respect to other insurance schemes proposed, is the use of an expert panel formed by 8 individuals representing all stakeholders to select which design is more adapted to the needs of the Spanish irrigators. The Panel included experts and stakeholders related to both water management in the Spain and the SCIS. As a result of the expert panel (the next section offers a detailed description), the best option to ensure irrigated crops in Spain would be a Hydrological Drought Index Insurance (HDII) contracted by the Irrigation District (ID). Index insurance to protect irrigators against water scarcity had already been proposed in the literature by Zeuli and Skees (2005) and Leiva and Skees (2008). However, we propose a simpler design, we detail the conditions that the ID should fulfill in order to be insured under this policy, and we analyze the hedging effectiveness of the instrument comparing the gross margin of the ID with and without the insurance contract. Similarly to Brown and Carriquiry (2007), we propose a unitary indemnity, but based on crop production and adapted to the ID. HDII is applied to the Bardenas Irrigation District V (ID-V). Besides, to respond to the interest shown by some Expert Panel participants, we discuss the possibility to subsidize the proposed insurance scheme within the EU legislative framework.

\subsection{Material and Methods}

\subsubsection{Selection of the insurance type: Expert panel}

An expert panel $^{2}$ was called on to define the insurance scheme the more appropriate to cover water supply risk in the Spanish irrigated agriculture, the difficulties that the implementation of this instrument would involve, and its potential acceptance among irrigators, insurance suppliers and the administration. The Panel met on May 2014 in the Technical University of Madrid with

\footnotetext{
${ }^{2}$ The Expert Panel is part of the project "Hydrological drought insurance for irrigation: an adaptation tool for climate change".
} 
four participants from IDs, one from crop insurance companies, one from the Ministry of Agriculture, one from the Spanish State Agency for Agricultural Insurance and one from River Basin Water Boards. Figure 3.1 represents the options proposed to the expert panel in respect to the insurance design and the policy holder. Conclusions derived from the expert panel development are exposed in next paragraphs and summarized in Figure 3.1.

\begin{tabular}{|c|c|c|}
\hline & Type of insurance scheme & $\begin{array}{l}\text { Insurance scheme demand } \\
\text { (policy holder) }\end{array}$ \\
\hline $\begin{array}{l}\text { Proposals to } \\
\text { Expert Panel }\end{array}$ & $\begin{array}{l}\text {-Traditional insurance } \\
\text { scheme with on field-loss } \\
\text { adjustment } \\
\text {-Index insurance scheme, in } \\
\text { which indemnity is based on } \\
\text { an objective indicator }\end{array}$ & $\begin{array}{l}\text { - Individual (farmer) } \\
\text { - Collective (ID) }\end{array}$ \\
\hline \multicolumn{3}{|l|}{ Expert Panel } \\
\hline Recommendation & Index insurance scheme & Collective \\
\hline Discussion & $\begin{array}{l}\text { Difficulties of } \\
\text { implementation } \\
\text { •Basis risk }\end{array}$ & $\begin{array}{l}\text { Difficulties of } \\
\text { implementation } \\
\text { •Potential difficulties in } \\
\text { premium and payments } \\
\text { distribution among irrigators } \\
\text { within the same ID } \\
\text {-Compulsory for all irrigators } \\
\text { within the same ID }\end{array}$ \\
\hline
\end{tabular}

Figure 3.1. Expert panel development and results. Source: own elaboration

Two types of insurance schemes were discussed (1) a traditional insurance scheme, with onfield loss adjustment, and (2) an index insurance. In this paper, we refer to index insurance as a type of weather or hydrological based index insurance, in which the indemnity is based on measurements of a specific weather or hydrologic parameter which is the Drought Index (DI). In the proposed index insurance the indemnities are calculated from an hydrological Drought Index which is multiplied by a unitary value of water (calculated from the added value of water of the region). Index insurance gathered more acceptances among the participants to the Expert Panel. Although on-field loss-assessment provides a better adjustment of the losses suffered by farmers, it is not compatible with water markets and transfer of water rights. An insured irrigator that sells water rights will suffer a yield loss and would receive a double compensation or payment for the loss, from the insurance scheme and from water rights transfer. In 
consequence, the sale of water rights is not permitted in this type of schemes. Besides, the use of more efficient irrigation methods, water banking and other water sources (via water markets, groundwater, desalinated water, etc.) is not encouraged, since the payoff is adjusted based on the yield finally obtained, so there is no interest in obtaining a higher yield. On the other hand, an index insurance, in which the indemnity is based on an external objective indicator, would be compatible with voluntary exchanges of water rights. In the case of an irrigator selling water rights, the index insurance scheme will only compensate for the potential loss associated to the Drought Index value, while the actual additional decrease in the crop production value due to the transfer of water rights will be compensated exclusively by the water rights price. In consequence both compensations are complementary, and do not overlap as in the previous case. At the same time, the use of more efficient irrigation methods, water banking and the use of other water sources is not discouraged. The farmer would still want to obtain the highest possible yield, since the insurance will anyway pay the indemnity that corresponds to the potential loss of each farm. Irrigators will not hesitate in buying water to other irrigators, investing on more efficient irrigation techniques, in order to obtain a higher yield. Index insurance is also easier to implement because there is no need to monitor moral hazard and to perform on field loss-assessment.

Several difficulties hindering the implementation of such scheme were identified. Basis risk is one of them, which implies that the payment may not necessarily correspond to the actual losses incurred by the insurance policy holder (Skees et al. 2008). This is due to the fact that there is some flexibility when applying water allocation rules. As a consequence, the relationship between indicator and water allotments may change from year to year. This flexibility in applying water distribution rules is transformed in basis risk of the index insurance. Basis risk leads to discontent among policyholders, and providers too. An example of the importance of basis risk in index insurance is the case of the Normalized Difference Vegetation Index or NDVI insurance for pasture in Spain, which has been in place since 2008 (Agroseguro 2015a). Due to the differences between payments and actual losses, the design is still being adapted in order to reduce the basis risk.

Concerning who should be the policyholder, either (a) individual farmer or (b) collectivity; a collective insurance policy, contracted by the ID as a whole, is preferred. This preference is explained by the fact that usually, within the same ID, irrigators do not receive the same water allotment per hectare. Water allotments for each irrigator are not only dependent on water availability, but they might be dependent as well on (i) the type of crops cultivated, (ii) water rights hold and /or purchased (in case there is a running water market) by the irrigator, and also on (iii) the quantity of water that each irrigator asks for at the beginning of the irrigation season. These water distribution mechanisms promote a more efficient use of water, since the most 
productive lands would probably receive more water than the least productive lands. But at the same time, all these variables (from (i) to (iii)) taking part in water distribution mechanisms within an ID make difficult defining clear rules in water distribution that would remain constant over the years. In consequence, a collective insurance policy is the insurance scheme most appropriate to cover water supply risk. Nevertheless, it was highlighted that the implementation of a collective policy, especially with regard to the premium share and the indemnities distribution, is a delicate issue, since individual risk aversion and cropping patterns might be highly diversified within the same ID. Additionally, the fact that the insurance is bought by the ID, makes it compulsory for all irrigators, even for those who are not interested in buying it.

According to the ideas drawn from the expert panel we conclude that the best option to ensure irrigated crops in Spain is a HDII contracted by the ID. HDII uses a Drought Index to estimate farmer losses due to water shortages. The unitary indemnity is given per $\mathrm{m}^{3}$ of water deficit per ha.

\subsubsection{Index insurance design, hedging effectiveness, and contract conditions}

The HDII defines a guaranteed level of water allotment measured in $\mathrm{m}^{3} / \mathrm{ha}$. This Guaranteed water allotment $(G W A)$ is the expected water allotment and is calculated as the average water allotment delivered to irrigators in the period analyzed. Water shortage in the ID $\left(w s_{t}\right)$ is measured in $\mathrm{m}^{3} /$ ha, and corresponds to the difference between the guaranteed water allotment or $G W A$ and the water allotment in year $t$ or $w a_{t}$ (equation 3.1):

$$
w s_{t}=\max \left(G W A-w a_{t}, 0\right)
$$

The water allotment in an ID $\left(w a_{t}\right)$ in a year $t$ is estimated from the Drought Index $\left(D I_{t}\right)$. The model $f$ is estimated empirically, from historical data (equation 3.2).

$$
w a_{t}=f\left(D I_{t}\right)
$$

The model reflects the decisions related to water management and infrastructure operations. The design of index insurance requires that hydrological data should be stationary (Drought Index and water allotments), otherwise detrending procedures should be implemented. In addition, operating rules should remain constant over the guarantee period of the contract. The selection of the index $D I$ in which the insurance should be based has been widely discussed in the literature (Bielza et al. 2008; Leiva and Skees 2008). The two basic prerequisites of an appropriate DI are: (1) high correlation with the potential loss, and (2) fulfillment of the quality standards of the insurance industry (transparent, verifiable, observable, reported in a timely manner, and not subject of manipulation). Underlying DI must be carefully selected or designed 
for each ID given the high diversification of irrigated crops, water sources, water management, and water irrigation practices (Vedenov and Barnett 2004).

The indemnity $\left(€ /\right.$ ha) received in a year $t$ results from multiplying $w s_{t}$ by a unitary indemnity that is equal to the water value $(w v)$ in $€ / \mathrm{m}^{3}$. A franchise deductible or $\gamma$ is the minimum amount of loss that must be incurred before insurance coverage applies (IRMI 2014). A $\gamma$ would help to decrease the premium rate and decrease operating costs of the insurance policy, since low severity losses would not be covered. Indemnity calculation in the presence of a $\gamma$ would then follow equation 3.3:

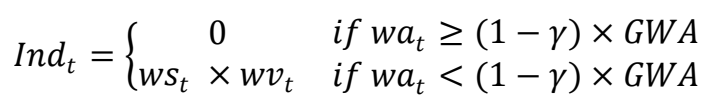

We estimate this unitary indemnity or $w v$ as a water value equivalent to the average decrease of expected gross margin exclusively due to the water shortage in the irrigated district. The productivity of water equals the revenue under irrigation minus the revenue under rainfed conditions (Lorite et al. 2012). Irrigation variable costs not incurred under water restriction situations should not be compensated; consequently the variable costs of irrigation are subtracted from water value. The fixed costs of irrigation (water basin authority fees, irrigation scheme infrastructure amortization/maintenance, and irrigation scheme personnel/administrative costs) should be compensated by the insurance indemnity, because they are borne by the farmers even if water deliveries are suspended during drought episodes. In consequence, they are not subtracted in the water value calculation. In any ID, crop pattern varies from year to year (unless the whole ID cultivates permanent crops) depending on the prevailing hydrological conditions. Therefore, we adapted the methodology applied by Lorite at al. (2012) to take this into account. Based on historical data, we established different crop pattern scenarios $S_{i}$ associated to a water allotment finally received in the farm $\left(w a_{i}\right)$. Several crop pattern scenarios were defined, ranging from a full rainfed scenario $\left(S_{0}\right)$ with no allocated irrigation water to a scenario with full guaranteed water allocation $\left(S_{I}\right)$, and including several intermediate scenarios $\left(S_{i}\right)$, where $i$ takes values between 0 and $I$. Each scenario has an associated value of agricultural production $\left(V A P_{i}\right)$ net of variable costs of irrigation $\left(V C I_{i}\right)$, that is equal to the Net Value of Agricultural Production $\left(N V A P_{i}\right)$, all three in $€ /$ ha (equations 3.4, 3.5 and 3.6):

$$
\begin{gathered}
V A P_{i}=\sum_{c=1}^{c=c}\left[S_{i c} \times Y_{c} \times P_{c}\right] \\
V C I_{i}=\sum_{c=1}^{c=C}\left[S_{i c} \times V C I_{i c}\right] \\
N V A P_{i}=V A P_{i}-V C I_{i}
\end{gathered}
$$


where $S_{i c}$ is the share of crop $c$ area on the ID for the $I$ scenario in the ID with $C$ crops, $Y_{c}$ and $P_{c}$ are the 5-year Olympic average ${ }^{3}$ of the irrigated yield and crop price in $\mathrm{kg} / \mathrm{ha}$ and $€ / \mathrm{kg}$ respectively; and $V C I_{i c}$ are the variable costs of irrigation converted in $€ /$ ha associated to the scenario $i$ for the crop $c$.

We estimate a water value that varies depending on the water allocated to the ID. The average water value corresponding to water allotment received is calculated comparing a scenario $S_{i}$ with the scenario with full guaranteed water allocation $S_{I}$ (equation 3.7):

$$
w v_{i}=w v_{i}\left(w a_{i}\right)=\frac{N V A P_{I}-N V A P_{i}}{G W A-w a_{i}}
$$

Consequently, there is an average water value for each water allotment $w a_{i}$ characterizing each scenario. Scenarios are always compared to the guaranteed water allotment (GWA) scenario $S_{I}$. With the discrete water values that arise from each scenario $i$, we can establish a relationship that will represent the water value (or unitary indemnity) to be applied dependent on the water allotment finally received (see Figure 3.2 and equation 3.8).

$$
w v_{t}=w v_{t}\left(w a_{t}\right)
$$

The liability or guaranteed value of the insurance scheme is determined following equation 3.9:

$$
\text { Liability }=G W A \times w v_{t}
$$

The threshold of the Drought Index that triggers a payoff (Trigger) meets equation 3.10:

$$
(1-\gamma) \times G W A=f(D I=\text { Trigger })
$$

The premium rate of the insurance scheme is calculated based on the expected indemnity (equation 3.11), where $t$ is the year and $T$ is the number of years:

$$
\text { Premium }=E\left(I n d_{t}\right)=\frac{1}{T} \times \sum_{t=1}^{t=T} \operatorname{In} d_{t}
$$

\footnotetext{
${ }^{3}$ The Olympic average is defined as an arithmetic mean calculated after first dropping the highest and lowest values within the last five years, measure that is established in the World Trade Organization's risk management agreements.
} 


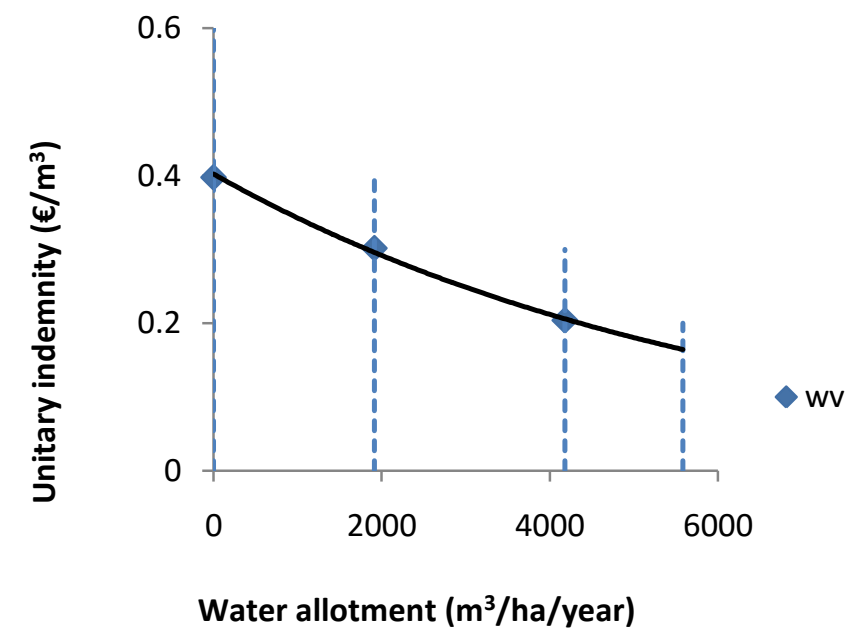

Figure 3.2. Water value depending on the water allocation received on the ID

All premium rates calculated in this paper are pure premiums, without subsidies or any additional costs. A charge to cover administrative, underwriting, reserves, reinsurance and operating costs should be added to the premium. However, the charge should be smaller than in traditional insurance because there is no need of on-field loss adjustment.

In case ligneous crops are present in the ID, several characteristics are to be considered when establishing the premium rate and the unitary indemnity: (i) crop distribution in the farm that presents exclusively ligneous crop does not change, consequently, the unitary indemnity to be received by the farmer is specific to the crop; (ii) unitary indemnity should reflect that ligneouscrop economic losses might be higher (investment is higher) and might be prolonged several years after the cause of loss, since the plant health might be threatened and next season's yield may be lower; (iii) Drought Management Plans in Spain prioritizes water allocation to ligneous crops over annual crops, in consequence risk of water shortage is smaller.

Basis risk of the index insurance is analyzed comparing insurance indemnities and actual losses. Insurance indemnities are calculated according to the index insurance scheme, so that water allotments are estimated from past records of drought indices. Actual losses are calculated directly from historical water allotments. The probable farmer losses and gains due to index insurance basis risk are denoted as basis loss and basis gain respectively (Zeng 2000).

The hedging effectiveness of index insurance is analyzed by comparing ID gross margin with and without the insurance contract, measuring the standard deviation (Kellner and Musshoff 2011). Additionally, we compare the mean root square loss (MRSL), and minimum gross margin with and without the insurance contract. In addition to the pure premium, we consider different premium loadings representing potential administrative and capital costs of the 
insurance company. MRSL is a simple function of the semivariance (i.e. losses) with respect to the gross margin trend without insurance (Vedenov and Barnett 2004).

The gross margin in the ID in a year $t\left(G M_{I D t}\right)$ is estimated considering the gross margin by crop $c\left(G M_{c}\right)$ and the surface that each crop represents in the ID that year $\left(S_{t c}\right)$. To estimate the gross margin in the ID with insurance, we should add the indemnity in the year $t\left(I n d_{t}\right)$ and subtract the premium rate (Premium) (equation 3.12).

$$
G M_{I D t}=\left(\sum_{c=1}^{C} S_{t c} \times G M_{c}\right)+\left(I n d_{t}-\text { Premium }\right)
$$

The average gross margin by crop is calculated following equation 3.13.

$$
G M_{c}=\left(Y_{c} \times P_{c}\right)-\left[\left(d c_{c}+e_{c}+l_{c}\right) \times Y_{c}\right]
$$

where $c$ is the crop, $Y_{c}$ and $P_{c}$ are the 5-year Olympic average of the irrigated yield and crop price in $\mathrm{kg} / \mathrm{ha}$ and $€ / \mathrm{kg}$ respectively; and $d c_{c}, e_{c}$, and $l_{c}$ are the 5-year Olympic average of the direct costs, equipment costs and labor force costs for producing $1 \mathrm{~kg}$ of crop $c$ (in $€ / \mathrm{kg}$ ). Direct costs include the costs of plants and seeds, fertilizers, and pesticides.

For calculating the gross margin, indirect costs, amortizations, and subsidies were not considered. Gross margin of fallow land was then equal to 0 . For the evaluation of the hedging performance of the index insurance, we considered a constant gross margin per crop, because the instrument is meant to stabilize the losses due to water scarcity, and not to changes in prices, production costs, or crop yields due to other causes (e.g. pests, temperatures, hail) than just water stress. In consequence, using the gross margin per year could distort the instrument performance.

In order to generalize the methodology, we detailed the conditions (C) that an ID should meet to be insured under the insurance scheme proposed. (C1) The ID (actual policy holder) assembles all irrigators that irrigate their farm from the same water source. The ID is responsible of the water distribution among irrigators and is in charge of collecting water fees. (C2) Ideally, water supply in the ID comes from a reservoir or a reservoir system situated in the headwaters, where inflows do not depend on human actions, but only on weather conditions. Otherwise, the Drought Index should be selected carefully in order to be objective. (C3) Water shortages cannot be predicted at the beginning of the crop season (the take up period). In other words, the correlation between historical volumes stored at the beginning of the crop season and the historical volume stored at the beginning of the irrigation season should be not significant. (C4) When implementing the insurance scheme, the payment of the premium and management of economic compensations in case of drought is carried out by the ID's managers. The ID distributes water, the premium share and the economic compensation between the farmers in 
order to optimize water productivity in the whole ID. The sharing rule shall be signed by every member of the ID.

\subsubsection{Description of the case study}

The region of study was selected in order to fulfill all conditions described in the previous section and is vulnerable to hydrological droughts. The most restrictive condition is $\mathrm{C} 3$, since it is common that reservoirs servicing the main irrigated areas store more than one-year of water demands to face drought episodes. Collaboration and data provided by the ID was also decisive to select the study area.

Case study selected is located in the Bardenas General ID, in the Ebro River Basin. It distributes irrigation water to 82,000 ha of irrigable land divided into 20 irrigation sub-districts (ID) located mainly in the province of Saragossa. Crop water demand is established at $7512 \mathrm{~m}^{3} / \mathrm{ha}$ (CHE, 2013). Each of the ID is responsible of the water distribution among the farmers. Our methodology is applied to the sub-district V (ID-V), located in Ejea de los Caballeros.

ID-V is serviced by the Bardenas Canal, which is serviced with water from the Yesa Reservoir (with a maximum capacity of $447 \mathrm{hm}^{34}$ ) on the headwaters of Aragón River. Yesa reservoir's purpose is mainly servicing the ID (irrigation represents $99 \%$ of the consumptive demands). Correlation between the Yesa Reservoir stocks in October and Yesa Reservoir stocks in May is equal to 0.21 and not significant (as indicated by the $p$-value $p>0.1$ ). In consequence, water scarcity cannot be predicted at the beginning of the crop season.

The Bardenas General ID is irrigated mainly by surface irrigation (78\%) and to a lesser extent by sprinkler irrigation $(22 \%)$. The main irrigated crops are winter cereals $(38 \%)$, maize $(21 \%)$ and alfalfa (20\%) (Bardenas 2012). Bardenas ID has been studied before by Causapé (2009), by Uku (2011), and by Ruiz et al. (2013). There is a Drought Management Plan (DMP) in the Ebro River Basin (CHE 2007) that establishes preparedness and mitigation measures, depending on the water supply system drought status (emergency, alert or watch, pre-alert and normality) that is determined by the DMP's Drought Status Indicator (DSI). The DSIs are calculated either from reservoir inflows, stocks, or in some cases piezometric levels and precipitation. DSI's are standardized between 0 and 1 (CHE 2007). The standardized values of the DSIs define the drought status according to basin-specific thresholds (Estrela and Vargas 2012). In emergency and in alert drought status ( 0 to 0.15 , and 0.15 to 0.30 respectively) the measures include restrictions in water allocation for agriculture, which get more severe as drought intensifies.

\footnotetext{
${ }^{4}$ Yesa reservoir enlargement Project is being executed since October 2014. It is expected that works will conclude by April 2018. Enlargement will allow to supply urban water to Saragossa, to Bardenas General Irrigation District, and to environmental purposes, and will reduce the risk of floods downstream Yesa reservoir (CHE 2014).
} 
Also priority in water uses is established, for instance, ligneous crops are given priority over other crops.

For the unitary indemnity calculation and for calculating the hedging effectiveness, data concerning provincial crop yields and national crop prices are sourced from the Statistical Yearbook data set published by the Ministry of Agriculture, Food and Environment (MAGRAMA 2014b). Crop surfaces and variable irrigation costs from ID-V are sourced from the Bardenas annual reports (Bardenas V 2015). Production costs in Bardenas and regional crop prices are sourced from Technical Reports (MAGRAMA 2012; MAGRAMA 2013a; MAGRAMA 2013b) ${ }^{5}$.

For the empirical estimation of the regression that estimates water allotments depending on the Indicator, Drought Status Indicators (DSI) are facilitated by the Confederación Hidrográfica del Ebro. Last, crop water allotments, are sourced from the Bardenas annual reports (Bardenas V 2015).

In order to estimate the unitary indemnity, depending on the water allotment finally received, we have defined different crop distribution scenarios (see Figure 3.3):

Fully irrigated scenario in Bardenas: crop surfaces and yields have been sourced from historical data under the 'normal' drought status following DSI definition which is DSI>0.5 (10 out of 13 years), which corresponds to the fully irrigated scenario.

Partial drought scenario in Bardenas: crop surfaces and yields have been sourced from historical data under drought status: 'pre-alert', 'alert' or 'emergency', according to DSI $(D S I<0.5)$. Water allotment associated to this scenario is the average of the water allotment received in the historical period under these circumstances ( 3 out of 13 years).

Extreme drought scenario in Bardenas: only rainfed crops. We have associated to the rainfed scenario $(w a=0)$ three hypotheses of crop distributions based on the discussion with irrigators. In these scenarios, surfaces dedicated to cereals, sunflower and fallow increase, and the surface dedicated to rice and maize (high water demanding crops) disappear. Alfalfa crop, being a multiannual crop, remains constant.

\footnotetext{
${ }^{5}$ Technical Reports are not publicly accessible. They have been provided by the Office of the Undersecretary General for Analysis, Prospective and Coordination at the Spanish Ministry of Agriculture, Food and Environment. Therefore, they are subject to a privacy commitment. They can be made available upon permission from Spanish Ministry of Agriculture, Food and Environment.
} 
(a)

\section{Fully irrigated}

wa $=7660\left(\mathrm{~m}^{3} / \mathrm{ha}\right)$

$\mathrm{VAP}-\mathrm{VCI}=1228(€ / \mathrm{ha})$

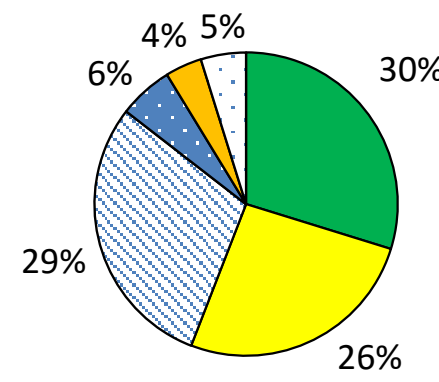

BARDENAS SCENARIOS

Partial drought

wa $=6010\left(\mathrm{~m}^{3} / \mathrm{ha}\right)$

VAP-VCI $=1032(€ / h a)$

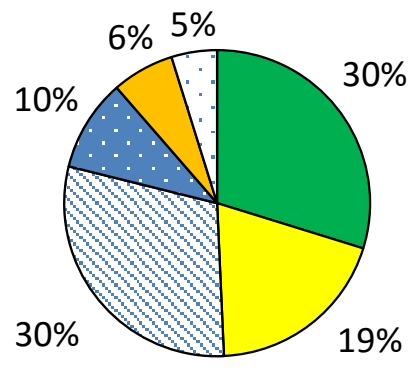

\section{Extreme drought}

$\mathrm{wa}=0\left(\mathrm{~m}^{3} / \mathrm{ha}\right)$

$\mathrm{VAP}-\mathrm{VCI}=355(€ / \mathrm{ha})$

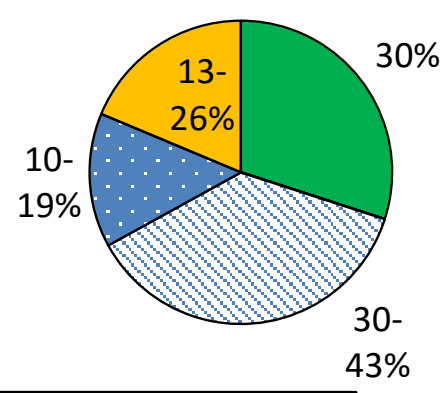

$\square$ Alfafa $\square$ Maize $\square$ Cereal $\square$ Fallow $\square$ Sunflower $\square$ Rice

$w a$ : water allotment correspondant to the scenario

VAP-VCI : Value of agricultural production (VAP) net of variable irrigation costs

GM: Gross margin, which is the VAP net of variable production costs.

Figure 3.3. Crop surface distribution, water allotment and NVAP associated to scenarios for the calculation of the water value (or unitary indemnity) in Bardenas

\subsection{Results}

\subsubsection{Index insurance design and premium rating}

We tested several DIs, and selected the one that best correlates with water allotments in the ID. The DIs tested are those defined in the 2007 Drought Management Plan (DMP), called Drought Status Indicators (DSI) measured in February, March, April, May and June, for regulated sections (DSI based on reservoir stocks) and non-regulated sections (DSI calculated from river flows) in the Aragon River Operating system (CHE 2007). The DI that best correlates is the one measured in February for the regulated section (correlation coefficient $=0.74 ; p$ value $=0.009$ ), based on water stocks in Yesa reservoir. Although DI represents accurately the water availability for irrigation, it might not be a valid index due to the fact that it can be manipulated and thus be subject to moral hazard (Brown and Carriquiry 2007; Zeuli and Skees 2005). In order to avoid moral hazard, the DI is predicted using an auxiliary Index (Aux I). The Aux I is the sum of the inflows between October and January (see equation 3.14). Using 2000-2013 data, the model that predicts DI is represented in equation 3.15. 


$$
\begin{gathered}
\text { Aux I }=\sum_{o c t}^{f e b} \text { inflows } \\
\widehat{D I}_{t}=f(\text { Aux I })=\operatorname{MIN}\left(0.9,0.0037 \times \operatorname{Aux} I^{* * *}-0.4788^{* * *}\right) \operatorname{Adj} R^{2}=0.34(n=14)
\end{gathered}
$$

Asterisks denote significance level ${ }^{*}=10 \%, \stackrel{* * *}{=}=5 \%$, and ${ }^{* * *}=1 \%$.

Linear and log linear models linking the DI selected and water allotments are compared by means of the Box-Cox transformation. Data series from 2000 to 2014 and OLS estimation were used for the model estimation. Despite the fact that water management regulations have changed (Drought Management Plan is being applied since 2007), water management rules are consistent over the whole period 2000-2014, since no statistically significant changes are detected before and after 2007.

Water allotments delivered in 2000 and 2001 are considered outliers, since they are far larger than the crop water demand that is planned in the River Basin Plan (CHE 2013), which equals to $7512 \mathrm{~m}^{3} / \mathrm{h}$. In consequence, we have included in the regression a Binary variable $d$ that controls for all years in which the water allotment is bigger than crop water demands established $(d=1)$, otherwise, $d=0$ means that water allotments are smaller or equal to crop water demands established. For the index insurance design, we use the regression where the Binary variable $d=0$. Water allotments are then estimated from $D I_{t}$ following equation 3.16 that is also represented in Figure 3.4:

$$
w a_{t}=5791^{* *}+D I_{t} \times 1235^{* *}+d \times 4005^{* *} \text { adj } \mathrm{R}^{2}=0.88(\mathrm{n}=15)
$$

Asterisks denote significance level ${ }^{*}=10 \%, \stackrel{* * *}{=}=5 \%$, and ${ }^{* * *}=1 \%$.

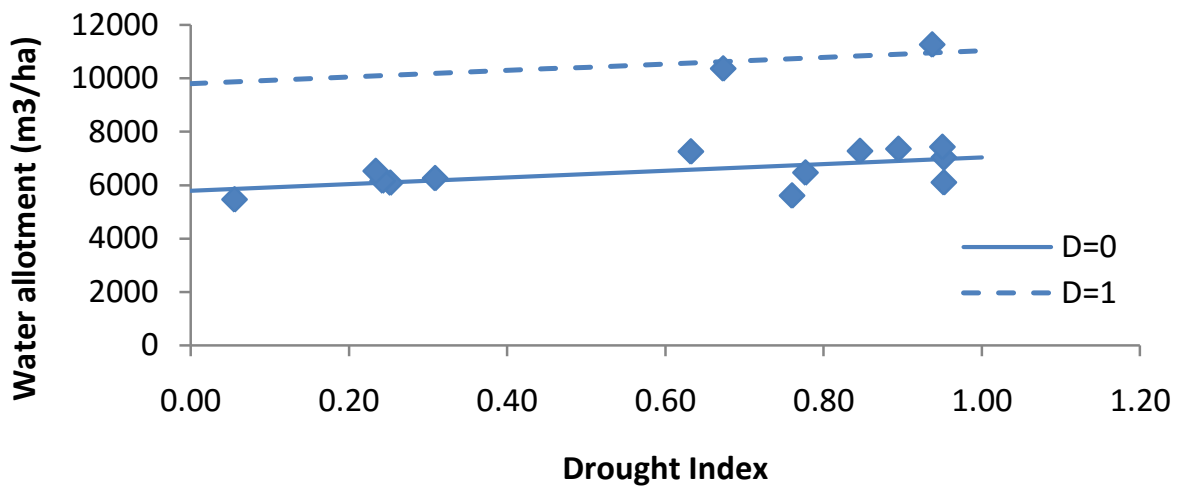

Figure 3.4. Model to estimate water allotments based on Drought Index based on 2000-2014 period

The crop surface distribution, the water allotment and the NVAP associated with each scenario described in previous section are presented in Figure 3.3. ID water values calculated following 
equation 3.7 are a set of values between 0.11 and $0.12 € / \mathrm{m}^{3}$. Given the small difference between the two values, for simplicity we applied the average water value as the unitary indemnity regardless of the water allotment received: $0.115 € / \mathrm{m}^{3}$.

The index insurance guarantees the average water allotment received in the ID in the period 2000-2014, for $d=0$ equal to $6537 \mathrm{~m}^{3} / \mathrm{ha}$. To avoid problems of adverse selection, insurance should be sold at the beginning of the crop season (October), before the rainfall and snow period begins. We have established two types of contracts: a scheme without Franchise Deductible (NFD) and with a Franchise Deductible (FD) equal to $8.6 \%$. The Franchise Deductible $\gamma$ is established in $8.6 \%$ so the Trigger corresponds to the threshold of the Drought Index indicating a status of Emergency (DSI=0.15). Premium rates, Liability and the Trigger are presented in Table 3.1. Premiums are calculated from both DI, and $\widehat{D I}$ based on data series from 1961 to 2014.

Table 3.1. Average indemnities, Guaranteed Water allotment (GWA), liability, premium rates and basis risk for HDDI in Bardenas, for an insurance scheme without Franchise deductible (NFD) and an insurance scheme with a franchise deductible (FD)

\begin{tabular}{|c|c|c|c|c|c|}
\hline & & \multicolumn{2}{|c|}{ NFD } & \multicolumn{2}{|c|}{ FD $(\gamma=8.6 \%)$} \\
\hline & & Actual DI & Estimated $\widehat{D I}$ & Actual DI & Estimated $\widehat{D I}$ \\
\hline \multirow{2}{*}{\multicolumn{2}{|c|}{$\begin{array}{l}\text { Average indemnity } \\
\text { GWA and liability }\end{array}$}} & \multicolumn{4}{|c|}{$0.115 € / \mathrm{m}^{3}$} \\
\hline & & \multicolumn{4}{|c|}{$6537 \mathrm{~m}^{3} / \mathrm{ha}$ and $752 € / \mathrm{ha}$} \\
\hline \multicolumn{2}{|c|}{ DI trigger (-) } & \multicolumn{2}{|c|}{0.6} & \multicolumn{2}{|c|}{0.15} \\
\hline \multirow{2}{*}{ Premium rate } & $\%$ (liability) & 1.77 & 1.33 & 0.4 & 0.61 \\
\hline & $€ /$ ha & 13.33 & 10.01 & 3.03 & 4.596 \\
\hline \multirow{2}{*}{ Basis risk } & Basis loss $\%$ & 2.19 & 2.3 & 1.85 & 1.88 \\
\hline & Basis gain $\%$ & 0.7 & 0.78 & 0 & 0.8 \\
\hline
\end{tabular}

In this research we have identified several sources of basis risk: basis risk associated to the selected Drought Index, and basis risk associated to the use of an Auxiliary Index to estimate water stocks in order to reduce the risk of index manipulation. Both measures of basis risk are disaggregated in basis loss and basis gain comparing indemnities from the insurance scheme (based on drought indices either actual or estimated) to potential indemnities calculated from past records of whole-farm $w a_{t}$ for the historical period 2000-2014 (see Table 3.1). Basis loss is always greater than basis gain, meaning that the insurance scheme is overestimating water allotments in the period 2000-2014.

\subsubsection{Hedging effectiveness}

In order to test the performance of the index insurance in reducing economic consequences of water supply risk, we compared the ID gross margin or $G M$ with and without insurance in the 
period 2000-2014. Data available for gross margin calculation by crop in ID-V is at Autonomous Community $^{6}$ scale (MAGRAMA 2012; MAGRAMA 2013a; MAGRAMA 2013b). Average gross margins by crop are calculated for the Aragon region considering data period 2007-2011. Alfalfa and forage gross margins are equal to $916 € /$ ha, maize gross margin is equal to $976 € /$ ha, cereals gross margin (soft and durum wheat and barley) is equal to 392 $€ /$ ha, sunflower gross margin is $24 € /$ ha and rice gross margin is $834 € /$ ha. Then gross margin in the ID by year is estimated considering average gross margin by crop and past records of crop surfaces in Bardenas ID-V for the period 2000-2014.

In addition to the pure premium rate, we consider premium loadings of $20 \%, 30 \%$, and $40 \%$, representing possible administrative and capital costs of the insurance company. Results of the hedging effectiveness analysis of the index insurance scheme can be observed in Table 3.2. Compared to the no insurance scenario, both insurance designs have a lower standard deviation of gross margins, a lower Mean Root Square Loss (MRSL), and a larger minimum gross margin, for the pure premium and for all different premium loadings. In comparing both insurance designs, the $\gamma=0 \%$ design seems the most effective in reducing risk exposure under all criteria, except for the MRSL criteria.

Table 3.2. Hedging effectiveness of the insurance schemes considering 2000-2014 period

\begin{tabular}{|c|c|c|c|c|}
\hline & $\begin{array}{c}\text { Premium } \\
\text { loading }\end{array}$ & $\begin{array}{c}\text { Gross margin standard } \\
\text { deviation }(€ / \mathrm{ha})\end{array}$ & $\begin{array}{c}\text { Minimum gross } \\
\operatorname{margin}(€ / \mathbf{h a})\end{array}$ & $\begin{array}{c}\text { Mean Root Square } \\
\text { Loss }(€ / \text { ha) }\end{array}$ \\
\hline Without insurance & - & 55.14 & 612.31 & 127.59 \\
\hline \multirow{4}{*}{$\begin{array}{l}\text { With Insurance } \\
\text { NFD }(\gamma=0 \%)\end{array}$} & $0 \%$ & 44.92 & 631.34 & 71.44 \\
\hline & $20 \%$ & 44.92 & 628.68 & 77.24 \\
\hline & $30 \%$ & 44.92 & 627.34 & 80.24 \\
\hline & $40 \%$ & 44.92 & 626.01 & 83.29 \\
\hline \multirow{4}{*}{$\begin{array}{c}\text { With Insurance FD } \\
\qquad(\gamma=\mathbf{8 . 6 \%})\end{array}$} & $0 \%$ & 50.59 & 628.6 & 69.14 \\
\hline & $20 \%$ & 50.59 & 628.0 & 70.56 \\
\hline & $30 \%$ & 50.59 & 627.7 & 71.27 \\
\hline & $40 \%$ & 50.59 & 627.4 & 71.99 \\
\hline
\end{tabular}

\subsection{Discussion}

The proposed insurance scheme has some issues related to its implementation that merit a few comments. Firstly, the implementation of the collective policy may confront some difficulties since all irrigators in the ID should agree on the decision to insure and on contract conditions. In

\footnotetext{
${ }^{6}$ Spain is divided in 17 regions, also called 'Autonomous Communities'.
} 
case farmers from the ID do not find a consensus that satisfies all of them, one alternative would be to establish individual contracts (so contract conditions $\mathrm{C} 1$ \& $\mathrm{C} 4$ would no longer be applicable). Individual contracts following the scheme proposed can only be established in the case water allocation between the farmers is fixed and not subject to the irrigators water allocation's requests. However, this is unlikely, since usually irrigators make a formal request to the ID concerning the water allocation they need. Then, ID tries to meet all irrigators' requests taking into account water availability and water rights. As a consequence, insurance is to be based on the average water allotment granted to the ID by the Basin Agency. The insurance design would then offer excessive coverage to irrigators cultivating low water demanding crops and would fall short offering coverage those cultivating high-water demanding crops. Another alternative would be to let the irrigators set freely the liability, as proposed by Zeuli and Skees (2005). The unitary indemnity received would change as a consequence and so would change the premium rate. The scheme would then work as a weather derivative, since the unitary indemnity is no longer estimated from past records of water allotments and gross margins in the farm. Therefore, this could lead to some disagreements with crop insurance laws, given that it could provide a coverage beyond the actual farm loss.

Secondly, the insurance scheme requires that water management rules should be implemented in full over the validity period of the insurance policy and no significant changes in water infrastructure should be observed. In case it does not hold, the model and all the calculations will need to be updated. Since there would not be historic data on DI and water allotments for the new situation, we could only rely on water simulation models to generate water allotments and DI values under the new situation. In case of technical change in crop production, it would not affect the index insurance model that estimates water allotments from a Drought Index. However, it might affect the water allotment guaranteed and also the unitary indemnity estimation, since technical changes would result in larger farmer's income, yielding higher gross margin for the same water allotment.

Thirdly, the probability and severity of droughts can also be influenced by climate change. Climate change introduces an additional factor of uncertainty in drought risks (Bielza et al. 2008). Increasing drought risk resulting from climate change affects the price of insurance in two ways. First, ambiguity and catastrophe loads may increase because uncertainty associated with future climate change impacts leads insurers to plan for the worst likely scenario when establishing these loads. Historical return periods may not be valid since they might underestimate the likelihood of agricultural losses in the future. Second, increasing drought risk changes the pure risk (Collier et al. 2009). In consequence, insurance parameters have to be adjusted over time to effectively hedge future weather risk (Kapphan et al. 2012). 
Finally, unitary indemnity estimation does not completely offset economic losses that might affect ligneous crops in case of drought, especially when drought affects production in subsequent years.

Some limitations specifically related to our findings for the Bardenas case study are associated to data availability. The unitary indemnity estimation and hedging effectiveness analysis rely on provincial and regional data, and not on local data. Besides, some of the crop patterns linked to water allotment scenarios, used for the unitary indemnity calculation, are designed based on the discussion with irrigators, due to the lack of longer data series. This could be a source of inaccuracies in the results that could be addressed with appropriate and longer data series. Collaboration among insurance companies, producers associations, and/or public entities would be required to have access to a more appropriate data. Besides, we have detected the presence of outliers in water allotments in the period analyzed, which had to be addressed including a Binary variable to the model.

Additional insight into the quality of our results is gathered by comparing our findings to previous literature results. Firstly, the liability of our insurance scheme (equal to $752 € /$ ha) is smaller than the liability reported by Ruiz et al. (2013) in a drought whole-farm insurance with on-field loss adjustment covering irrigated crops, also in Bardenas (equal to $1488 € / \mathrm{ha}$ ). This difference is due to the fact that our index insurance scheme takes into account that farmers not being able to irrigate may still have the alternative of producing rainfed crops (when cultivating annual crops), and thus earning some revenue (except for the case of rice, which is cultivated on marginal soils). Secondly, our unitary indemnity estimation can be compared to Lorite et al. (2012) works in a southern river basin in Spain. We obtained a unitary indemnity of $0.115 € / \mathrm{m}^{3}$ that is in the range of Lorite et al. (2012) results: wheat $\left(0.054 € / \mathrm{m}^{3}\right)$, sunflower $\left(0.092 € / \mathrm{m}^{3}\right)$, and maize $\left(0.15 € / \mathrm{m}^{3}\right)$.

There are some issues about the use of the Auxiliary Index, which is required in case the selected DI might be subject to manipulation. One disadvantage of its use is the increase in basis risk. In our case study, the use of an Auxiliary Index increases basis loss $(0.11 \%$ for NFD and $0.03 \%$ for FD) and basis gain ( $0.08 \%$ for NFD and $0.8 \%$ for FD). Another important fact to take into account is that the Auxiliary Index would not reflect some impediments that might prevent water from being delivered to irrigators, such as a breakdown in the canals or conveyance system, or a pollution problem. Under these circumstances, irrigators would not receive an indemnity, but would suffer economic losses. This would need to be clearly stated in the policy wording. If water management is performed according to predefined rules, there would be no need of such an Auxiliary Index, which may be warranted when the selected DI (e.g. water 
stocks in the reservoir) might be subject of manipulation. This would need further discussion with all stakeholders involved.

It is interesting to observe how basis risk is distributed among basis loss and basis gain. Ideally basis loss and basis gain should be similar, so the insurance scheme is favoring neither the farmer nor the insurance company. In Bardenas, basis loss in the analysis period is larger than basis gain in all cases, meaning that the insurance scheme is overestimating water allotments. This is due to the fact that in several years the DI was above the trigger, and irrigators received a water allotment below the guaranteed water allotment. These cases would require further investigation. Despite this, the hedging effectiveness analysis shows that NFD and FD insurance schemes are effectively reducing risk exposure, even considering a $40 \%$ premium load to cover administrative and capital costs of the insurance company. Note that premium loading for the FD scheme might be smaller than for the NFD scheme, because the more frequent the payoffs take place, the higher the administrative costs that the insurance company is going to charge.

Results suggest that the insurance scheme would be useful to provide economic stability to IDs. It would constitute a means for irrigators to adapt to climate variability and it could encourage investment in irrigation technologies as a means of adaptation for dryland farmers. It would also promote a more efficient use of the irrigation water. This insurance can be generalized to any ID fulfilling the conditions mentioned in Section 3.3.2 of this paper. IDs not fulfilling condition C3 "Water shortages cannot be predicted at the beginning of the crop season (the take up period)" might be subject to intertemporal adverse selection. Intertemporal adverse selection comes from the fact that pre-season weather information can influence crop insurance decisions (Carriquiry and Osgood 2012), as farmers could use this information to purchase insurance only in years with enhanced drought risk and probability of payout (Luo et al. 1994). Further research is needed to propose other insurance schemes dealing with intertemporal adverse selection.

The use of an expert panel to determine the type of insurance scheme that better fits with the Spanish framework is expected to bridge the gap between theory and practice, contributing to a more attractive and adapted insurance scheme to local conditions. Further discussions with the expert panel exploring the implementation difficulties of the insurance scheme selected and developed would be of interest for the research.

Public support to index insurance is currently accepted in EU legislation, under certain conditions. Specifically, the EU Guidelines 2014 to 2020 on State Aid (EC 2014) and the Regulation for EU support for Rural Development (EU 2013) refer to insurance premiums ${ }^{7}$ of schemes (i) using "weather indexes (including quantity of rainfall and temperature) established

${ }^{7}$ The gross aid intensity must not exceed $65 \%$ of the cost of the insurance premium (EU 2013 (Annex II); EC 2014 (art 412)). 
at local, regional or national level" to quantify the economic losses. For that, (ii) "the occurrence of an adverse climatic event has to be formally recognized as such by the competent authority of the Member State concerned" and (iii) financial contribution to premiums for crop insurance shall only be granted for insurance contracts which "cover for loss caused by an adverse climatic event, which destroys more than $30 \%$ of the average annual production of the preceding three-year period or the 5-year Olympic average". Concerning our HDII, although EU legislation and Guidelines allows the use of weather indexes (including quantity of rainfall and temperature), streamflows or water stocks (in which our DI is based) are not explicitly mentioned as weather indexes and could be manipulated. In the case streamflows and specially water stocks would not be accepted as weather variables, auxiliary indexes could be used, with the consequent increase in basis risk. The compliance with condition (ii) would not represent a problem as it would easily be reached if the DI triggering the indemnity was at the same time an official indicator that indicates a natural disaster, which is the case in our insurance scheme. Particularly, the FD scheme is triggering a payment whenever the DI indicates a status of Emergency. Lastly, the use of a Franchise Deductible $(\gamma)$ might help comply with condition (iii). In our case study, the FD scheme has established a $\gamma$ at $8.6 \%$ of the water allocation. Although water allocation and annual production might not follow a linear relationship, a $\gamma$ of less than $10 \%$ of water deficit would probably be far from being equivalent to the $30 \%$ required (moreover, in the period analyzed, there are not historic records showing a 30\% loss in terms of water allotment). Although the insurance scheme in our case study will not be considered to be compatible with EU legislation ${ }^{8}$, FD scheme in other regions would be, provided irrigators would be exposed to water shortages destroying more than $30 \%$ of the average annual production and the Drought Index would be accepted as a weather variable.

The main strength of this insurance scheme is the compatibility with water markets, water banking, transfer of water rights, and groundwater use. Another important strength is that farmers might receive the economic compensation as soon as the DI is measured, far before the end of the crop season, allowing them to have ready cash for any eventuality arising in the crop season, such as the possibility of participating in water market mechanisms.

${ }^{8}$ It could be subsidized from national funds under De Minimis rule (EC, 2006). 


\section{DEALING WITH INTERTEMPORAL ADVERSE SELECTION IN HYDROLOGICAL DROUGHT INDEX INSURANCE}

In previous chapter, the need of alternative schemes that take into account that water shortages might be predicted (i.e. inertial water supply systems) is highlighted. This chapter presents several index insurance schemes aiming to avoid the intertemporal adverse selection. To illustrate the different schemes a case study showing inertial behavior is selected in the Guadalquivir Basin.

Publication: Maestro T, Bielza M, Garrido A. Dealing with intertemporal adverse selection in hydrological drought index insurance. Water Resources and Economics (submitted)

\subsection{Abstract}

Hydrological drought is a major risk for irrigated agriculture in most world regions. Hydrological based index insurance may help farmers manage the risk of losses related to water shortage. In numerous water supply systems (i.e., presenting inertial behavior), water shortages might be predicted in advance, leading to intertemporal adverse selection of the insurance policy. In this paper, several index insurance schemes are proposed to avoid the intertemporal adverse selection (i) using a pre-season index to adapt the premium to the actual risk undertaken, under a one-year policy or under a multi-year policy, and (ii) selling early-bird contract at a constant premium, before the drought can be predicted. To illustrate the different schemes and to analyze differences in premium rates, a case study showing inertial behavior is selected in the Guadalquivir Basin, in the south-west of Spain. Premium rates and basis risk are calculated from historic series of drought indices and water allotments. The methodology can be applied to many other water supply systems around the world and to other insurance schemes presenting intertemporal adverse selection linked to weather events that might be forecasted in advance (e.g., El Niño event).

\subsection{Introduction}

Meteorological droughts predate hydrological droughts, reducing the availability of surface and groundwater sources, and giving rise to water shortages for consumption uses and environmental flows. Irrigated farms suffer economic losses when water allocations decrease in 
years of hydrological drought. Climate change projections indicate that droughts will intensify in the $21^{\text {st }}$ century in southern Europe and the Mediterranean region, central Europe, central North America, central America and Mexico, northeast Brazil, and southern Africa (IPCC 2012). In consequence, the risk of hydrological drought will increase, even if average expected runoff remains constant.

In order to stabilize farmers' income, the risk component of drought can be coped with or managed using various instruments. In addition to water markets (Easter and Huang 2014), option contracts and insurance are also means to manage water supply instability (Rey et al. 2015). Examples of these instruments are found in the literature. Rey et al. (2015) and Tobarra and Castro (2011) calculate the cost of water uncertainty for a risk averse farmer in the Segura Basin. Other authors propose insurance traditional schemes, using crop production functions and crop simulation models to assess the economic impact of drought in some irrigated regions of Spain (Pérez Blanco and Gómez Gómez 2013; Quiroga et al. 2011; Ruiz et al. 2013). In the United States, the Crop Insurance Program offers the possibility of covering irrigated yield losses due to a failure of irrigation water supply. Farmer can insure under irrigation only the acreage that would be fully irrigated considering the expectations of water availability at the beginning of the crop season (when insurance attaches). Expectation of water availability is based on the water available in reservoirs, soil moisture levels, snow pack storage levels (if applicable) and precipitation which would normally be received during the crop season. The other acreage may be reported as prevented planting and/or rainfed. Prevented planting acres are subject to an indemnity under the Prevented Planted Provision. Instead of reducing the irrigated acreage, farmer can as well plant all acres with limited irrigation water, but it would be insured under non-irrigated practices. Failure in irrigation water supply must be due to a naturally occurring event. Decreased water allocation resulting from the diversion of water for environmental reasons, compact compliance, selling water to municipalities, or other causes not covered under the policy are not insurable causes of loss (RMA-Topeka 2015).

In this article, we discuss an index insurance scheme for protecting farmers from losses in irrigated agriculture due to hydrological drought. Index insurance is applied as well to others fields. In particular there is a substantial literature on the energy utilities sector (Cao and Wei 2004). There is a high correlation between power consumption and temperature averages, so energy suppliers can hedge their seasonal weather risk contracting weather derivatives or some other financial contract (Changnon 2007; CME Group 2015). In this paper, we refer to hydrological index insurance in which the indemnity is based on measurements of a specific weather or hydrologic parameter which is the drought index. The advantage of index insurance compared to traditional insurance schemes is that there is no need to perform on-field loss adjustment and to monitor moral hazard because the farmer cannot influence the likelihood and 
the magnitude of the indemnity. Another advantage is that the cost of the insurance may be lower and it might be administered electronically, knowing simple hydrological status variables.

There is no reference in the academic literature of commercially offered hydrological drought index insurance for irrigated agriculture. However, the application of index insurance for rainfed agriculture is implemented in several countries to protect against different risks: satellite imagery index insurance in Spain to protect pastures against meteorological drought (Agroseguro 2015a); rainfall index insurance in India to protect against meteorological drought and flood (AIC 2015); rainfall-based drought index insurance for coffee farmers in Vietnam (The insurer, Bao Minh company, stopped offering the insurance after two consecutive years of losses, in 2011 and 2012 (Mai and Hung 2013) to cover additional costs of irrigation during a drought period (GlobalAgRisk 2009). Information about other index insurances applied in agriculture can be found in Bielza et al. (2008), Hellmuth et al. (2009), Mahul and Stutley (2010), and Skees et al. (2008).

Although not commercially offered, several drought index insurance mechanisms have been proposed in the literature seeking to cover financial risks for water managers (Brown and Carriquiry 2007; Zeff and Charaklis 2013) and offering covers for agricultural production (Zeuli and Skees 2005; Leiva and Skees 2008). Brown and Carriquiry (2007) use seasonal inflows to develop an index insurance that compensates an urban water supplier for the increased costs associated with acquiring water from irrigators during dry periods via option contracts. Zeff and Charaklis (2013) propose an index insurance based on streamflows and withdrawals from a multi-reservoir system that generally refills each year. They propose a contract that is purchased once per year at the beginning of the irrigation season, when reservoir levels are typically full. Zeuli and Skees (2005) propose a financial product called cumulative Rainfall Insurance Contract in a New South Wales irrigation district in Australia, to manage water supply risk. For the implementation, historic rainfall levels need to be highly and positively correlated to historic reservoir water levels. The coverage level and liability is chosen by the insured and are independent from the crops in the farm. Leiva and Skees (2008) propose an index insurance presenting two types of contracts, based on 12 or 18-month river flow accumulation in the whole Rio Mayo irrigation system in northwestern Mexico. Cumulated river flows are highly correlated to annual plantings. The insured district obtains an indemnity based on the district average expected income per ha, when the accumulation of reservoir inflows falls below a predetermined threshold.

The main disadvantage of index insurance is basis risk, which implies that the payment may not necessarily correspond to the actual losses incurred by the insurance policy holder (Skees et al. 2008). In order to reduce basis risk, several authors propose the use of mixed indices (Kapphan 
et al. 2012; Kellner and Musshoff 2011) or designing multiscale contracts (Elabed et al. 2013). Both options can lower the basis risk, but in turn the insurance becomes less comprehensible for the insured farmer (Kellner and Musshoff 2011), so simpler indices are more desirable. Another problem associated to hydrological drought insurance is that water shortages can be predicted in advance in regions in which reservoirs do not refill each year and can hold several years of water supply (i. e., inertial systems), giving rise to intertemporal adverse selection. Intertemporal adverse selection refers to the behavior of an insurance buyer selecting only highrisk periods to purchase insurance with no adjustments being made by the seller to reflect this behavioral pattern (Luo et al. 1994). Carriquiry and Osgood (2012) explore the interaction between climate forecasts and index insurance and also include climate forecasts in index insurance premium rating to address this problem.

In this paper we focused on inertial systems and we proposed several index insurance schemes for avoiding the intertemporal adverse selection: (i) using a pre-season index (PSI) to adapt the premium to the actual risk undertaken, under a one-year policy or under a multi-year policy, and (ii) selling early-bird contract at a constant premium, before the drought can be predicted. We have selected a case study in Spain presenting an inertial behavior to illustrate the different schemes proposed. The study area is El Viar Irrigation District (VID), situated in the Guadalquivir River Basin, in the south-west of Spain.

The structure of the paper is as follows. The theoretical framework is explained in Section 4.3. Section 4.4 presents the case study, Section 4.5 discusses the results, and Section 4.6 summarizes the main conclusions.

\subsection{Theoretical framework}

\subsubsection{Drought index}

Index insurance uses an objective measure as a proxy for individual losses. In water supply systems, the economic loss is clearly related to water shortages. Index insurance schemes proposed in the literature for water supply systems are based on a cumulated rainfall index that is correlated with reservoir levels (Zeuli and Skees 2005); a cumulated river flow index (Leiva and Skees 2008; Brown and Carriquiry 2007); and a weekly balance between reservoir inflows and withdrawals (Zeff and Charaklis 2013).

The selection of the index in which the insurance should be based is widely discussed in Bielza et al. (2008) and Leiva and Skees (2008). The two basic prerequisites of an appropriate index 
are: (1) high correlation with the potential loss and (2) fulfillment of the quality standards in the risk-sharing and financial industry (transparent, verifiable, observable, reported in a timely manner, and not subject of manipulation). In consequence, volume stored in reservoirs at the beginning of the irrigation season might not be a valid index due to the fact that it can be manipulated and thus be subject to moral hazard (Brown and Carriquiry 2007; Zeuli and Skees 2005).

To eliminate conflicts of interest between water users when the water is scarce, water supply systems often establish institutional rules to allocate the water between users based on objective measures. These objective measures are commonly based on hydrological variables such as reservoir stocks, streamflows, groundwater levels, precipitation forecasts, and may be aggregated in a drought index. The presence of an institutional rule facilitates the design of the index insurance. Water deficit suffered by farmers may be estimated based on this institutional rule and an economic compensation per cubic meter of water deficit might be given to the irrigator. The hydrological variable or drought index used in the institutional rule should meet the required standards and prerequisites mentioned above for the selection of the index in which the insurance should be based. In the case it does not, an auxiliary index that would be highly correlated with the mentioned hydrological variable would be used instead.

\subsubsection{Indemnity calculation}

We assume that the water supply system allocates water to irrigators based on an institutional rule. In the case it does not, a drought index, meeting the required standards and prerequisites mentioned in the previous section should be identified and the model linking drought index and water allotments would be estimated empirically.

The proposed insurance scheme guarantees a level of water allotment measured in $\mathrm{m}^{3} / \mathrm{ha}(G W A)$ for the whole-farm. Under whole-farm insurance, the farmer is free to cultivate any type of crop. Water allotment $\left(w a_{t}\right)$ in a year $t$ in the farm is estimated from the drought index $\left(D I_{t}\right)$ based on the institutional rule $f$ (equation 4.1).

$$
w a_{t}=f\left(D I_{t}\right)
$$

Water deficit in the whole-farm $\left(w d_{t}\right)$ is measured in $\mathrm{m}^{3} /$ ha, because irrigation area is considered fixed (ha). It corresponds to the difference between the guaranteed water allotment expressed in $\mathrm{m}^{3} /$ ha $(G W A)$ and the water allotment in year $t$ or $w a_{t}$ in $\mathrm{m}^{3} /$ ha (equation 4.2). GWA is the water allotment set to irrigators under normal circumstances following the institutional rule.

$$
w d_{t}=\max \left(G W A-w a_{t}, 0\right)
$$

Economic losses in the irrigated farm are represented by an unitary indemnity in $€$ per cubic meter that corresponds to the water value. The water value must correspond to the average 
decrease of profit exclusively due to the water shortage in the irrigated farm, expressed in $€$ per cubic meter. Water value estimation may be based on the Residual Value Method described in Berbel et al. (2011). Following Berbel et al. (2011), the residual value of water is the output value that remains once all inputs and factors are paid, including cash payment to external factors and the opportunity cost of the fixed factors such as land (estimated as rainfed productivity), family unpaid labor, interest on owned built capital, and management, per unit of irrigation water applied. When applying an unitary indemnity based on the residual value method, we are not compensating the costs of inputs and factors, but we are compensating the fixed costs of irrigation and the variable costs of irrigation. The fixed costs of irrigation (water basin authority fees, irrigation scheme infrastructure amortization/maintenance, and irrigation scheme personnel/administrative costs) should be compensated by the insurance indemnity, because they are borne by the farmer even if water deliveries are suspended during droughts.

The payoff in $€ /$ ha in a year $t$ is the result of multiplying water value $(w v)$ in $€$ per $\mathrm{m}^{3}$ and water deficit $(w d)$ in $\mathrm{m}^{3} / \mathrm{ha}$. A franchise deductible $(\gamma)$ can be applied to the index insurance design in order to reduce the premium rate. $\gamma$ is the minimum amount of loss in percentage of the Guarantee Water Allotment, that must be incurred before insurance coverage applies. A franchise deductible differs from an ordinary deductible in that, once it is met, the entire amount of the loss is paid. Then, the indemnity for year $t\left(\operatorname{Ind}_{t}\right)$ would be calculated according to equation 4.3:

$$
\operatorname{Ind}_{t}=\left\{\begin{array}{cc}
0 & \text { if } w a_{t} \geq(1-\gamma) \times G W A \\
w d_{t} \times w v & \text { if } w a_{t}<(1-\gamma) \times G W A
\end{array}\right.
$$

\subsubsection{Premium rating}

We can define inertial water supply systems as those systems in which water shortages caused by hydrological drought can be predicted at the beginning of the crop season that usually corresponds to the date when the policy is underwritten. This occurs in hydrological systems where reservoir capacity is large relative to annual inflows and water demands. This can lead to a significant risk of intertemporal adverse selection for insurance companies: farmers would insure their crops only when drought is anticipated. The risk of intertemporal adverse selection implies the need of special index insurance schemes: (i) Premium rates depending on a preseason index and, (ii) Early-bird contract with a constant premium rate.

All premium rates calculated in this paper (under (i) and (ii) schemes) are actuarially fair premiums, which corresponds to the expected indemnity paid to policyholders without subsidies and any additional costs. A charge to cover risk margin and administrative operating costs 
(Bielza et al. 2008) should be added to the premium. However, the charge should be smaller than in traditional insurance because there is no need for on-field loss adjustment.

Historical data series of drought indices should be stationary (i.e., risks are constant) for calculating premium rates. If there is a trend, a detrending procedure is performed.

\section{(i) Premium rates depending on a pre-season index}

One way to avoid intertemporal adverse selection is to consider the hydrologic status at the moment of the policy purchase. For that, we propose the use of a pre-season index (PSI) that adapts the premium rate to the actual risk that the farmer is facing. The PSI differentiates two or more drought probability levels (pre-season scenarios) at the moment of the policy purchase. For simplicity we show here only two pre-season scenarios but there might be more than two. A threshold $t r$ is the trigger that defines the status of expected normality (en) or expected drought (ed) (equation 4.4):

$$
\text { Pre-season scenario } \begin{cases}\text { en } & \text { if PSI }>t r \\ \text { ed } & \text { if } P S I<t r\end{cases}
$$

For a one-year policy, the premium rate for expected normality en is calculated as the expected indemnity in the $N$ years that the pre-season index PSI indicates expected normality (equation 4.5). The premium rate for expected drought $e d$ is calculated as the expected indemnity in the $D$ years that the pre-season index $P S I$ indicates expected drought, where $K$ is the total number of years in the available time series $(K=N+D)$ (equation 4.6):

$$
\begin{array}{ll}
\text { Premium 'en' }=\frac{1}{N} \times \sum_{t=1}^{t=\mathrm{K}} \text { Ind } & \forall t \mid P S I>t r \\
\text { Premium 'ed' }=\frac{1}{D} \times \sum_{t=1}^{t=K} I n d_{t} & \forall t \mid P S I<t r
\end{array}
$$

This procedure can be done for as many pre-season scenarios as desired (not just $e n$ and $e d$ ).

Multiyear contracts are a particular case of the scheme (i), because premiums are still dependent on the hydrological status when buying the insurance policy. Multi-year contracts can be designed in order to average-out the premium rates between the different pre-season scenarios. For a x-year policy, premiums are calculated as the expected $x$-year average indemnity or $x_{\text {ave }}$ Indt (see equation 4.7 to 4.9 ):

$$
\begin{aligned}
& \text { xave }_{\text {Indt }}=\frac{1}{x} \times \sum_{t=t-(x-1)}^{t=t} \operatorname{Ind}_{t} \\
& \text { Premium 'en' }=\frac{1}{N} \times \sum_{t=1}^{t=\mathrm{K}} \text { xave }_{\text {Indt }} \quad \forall t \mid \text { PSI }>\text { tr }
\end{aligned}
$$




$$
\text { Premium 'ed' }=\frac{1}{D} \times \sum_{t=1}^{t=K} x a v e_{\text {Indt }} \quad \forall t \mid P S I<t r
$$

(ii) Early-bird contract with a constant premium rate

Another option would be to offer the insurance before the hydrological signals indicate that water shortages might occur during the irrigation season. In this case, premium rate is constant and is calculated as the expected indemnity, which is calculated considered whole data series following equation 4.10 , where $t$ is the year and $K$ is the number of years:

$$
\text { Premium }=\frac{1}{K} \times \sum_{t=1}^{t=\mathrm{K}} \operatorname{Ind}_{t}
$$

\section{Basis risk}

In order to evaluate the different contract options, we calculated the basis risk associated to each of them. A way of measuring basis risk is evaluating the adjusted $\mathrm{R}^{2}$ measures between the index and the actual losses (Vedenov and Barnett 2004). However, it does not quantify the basis risk in a language familiar to insurance/actuarial professionals (Zeng 2000). Instead, we proposed as a measure of basis risk the expected difference between the insurance indemnities $\left(I n d_{t}\right)$ calculated according to equation 4.3 and actual losses $\left(L_{t}\right)$ calculated directly from historical water allotments. For both $I n d_{t}$ and $L_{t}$ we applied the same franchise deductible. Basis risk can be disaggregated into basis loss (probable farmer losses due to index insurance) and basis gain (probable farmer gains due to index insurance) (Zeng 2000) following equation 4.11 and 4.12 respectively. Due to the fact that insurance indemnities are calculated following the institutional rule, we can specify the origin of the basis risk and we may call it institutional risk of the index insurance, because it comes mainly from the institutional uncertainty in applying the established rules.

$$
\begin{array}{ll}
b l(€ / h a)=\frac{1}{k} \times \sum_{t=1}^{t=k}\left[\operatorname{Ind}_{t}-L_{t}\right] & \forall t \mid\left(\operatorname{Ind}_{t}-L_{t}\right)<0 \\
b g(€ / h a)=\frac{1}{k} \times \sum_{t=1}^{t=k}\left\lfloor\operatorname{Ind}_{t}-L_{t}\right\rfloor & \forall t \mid\left(\operatorname{Ind}_{t}-L_{t}\right)>0
\end{array}
$$

Basis risk (basis loss and basis gain) can be expressed in terms of percentage over the liability (which is equivalent to the Guaranteed Water Allotment times the waver value). 


\subsection{Case study}

El Viar Irrigation District (VID) is situated in the province of Seville and is part of the Guadalquivir River Basin. Most of the water in VID (90\%) comes from El Pintado Reservoir (maximum capacity of $213 \mathrm{hm}^{3}$ ) and the remainder from two pump stations situated downstream on the Guadalquivir River (CHG 2007). Groundwater pumping is minoritary. El Pintado Reservoir operates since 1951 and was erected in 1949 to provide irrigation water to El Viar irrigators.

VID has an open channel distribution network, with water supplied in turn according to a prearranged agreement. In VID, users pay a fee based on their irrigated area irrespective of their volumetric water consumption (Rodríguez Díaz et al. 2007). A project updating the irrigation system in VID is taking place. It will pressurize the network and it will allow irrigation on demand and a fee based on the volumetric consumption (MAGRAMA 2013c). Around 12,000 ha are irrigated each year. Crop distribution is dominated by orange trees (41\%), cotton (20\%), and maize (31\%). VID was irrigated entirely by surface irrigation in the 2012 irrigation season (El Viar Irrigation District, personal communication). VID has been studied previously by Iglesias et al. (2003), Iglesias et al. (2007) and by Rodriguez et al. (2008).

In order to deal with hydrological drought, the Spanish Hydrological Plan Act (Law 10/2001) established that Drought Management Plans (DMP) had to be elaborated by river basin authorities. Drought management decisions should be based on a national hydrologic indicator system. In Guadalquivir River Basin, the DMP establishes water releases to agriculture in VID depending on water stocks in El Pintado Reservoir at the end of April, which constitutes the April drought status index ( $D S I_{A p r}$ ) (CHG 2007). Following DMP instructions, no constraints on water allotments are applied if stocks at the end of April are $125 \mathrm{hm}^{3}$ or above and, under normal circumstances, at least $67 \mathrm{hm}^{3}$ are allocated to crops in the whole district. If the stored volume is below $125 \mathrm{hm}^{3}$, the amount of water allotted to agriculture decreases in proportion to the DSI, according to an established chart that can be found in the DMP and that is represented in Figure 4.1 under the label "DMP Guidelines". In Figure 4.1 triangles represent the pairs "historical water releases - DSI" for the 1990-2012 period. Historical water allotments are sourced by VID (personal communication) and DSI are available as Supporting Information and are sourced from the Statistical Yearbook (MAGRAMA 2015) for the period 1953-2009, and from the Automatic Hydrologic Data Collection System (CHG 2015) for the period 2010-2012. We observe in Figure 4.1 that the line representing the DMP Guidelines appears to be a good estimator of the minimum water volume expected to be supplied to agriculture depending on the level of water reserves in El Pintado Reservoir. Just a few points are below the line. 


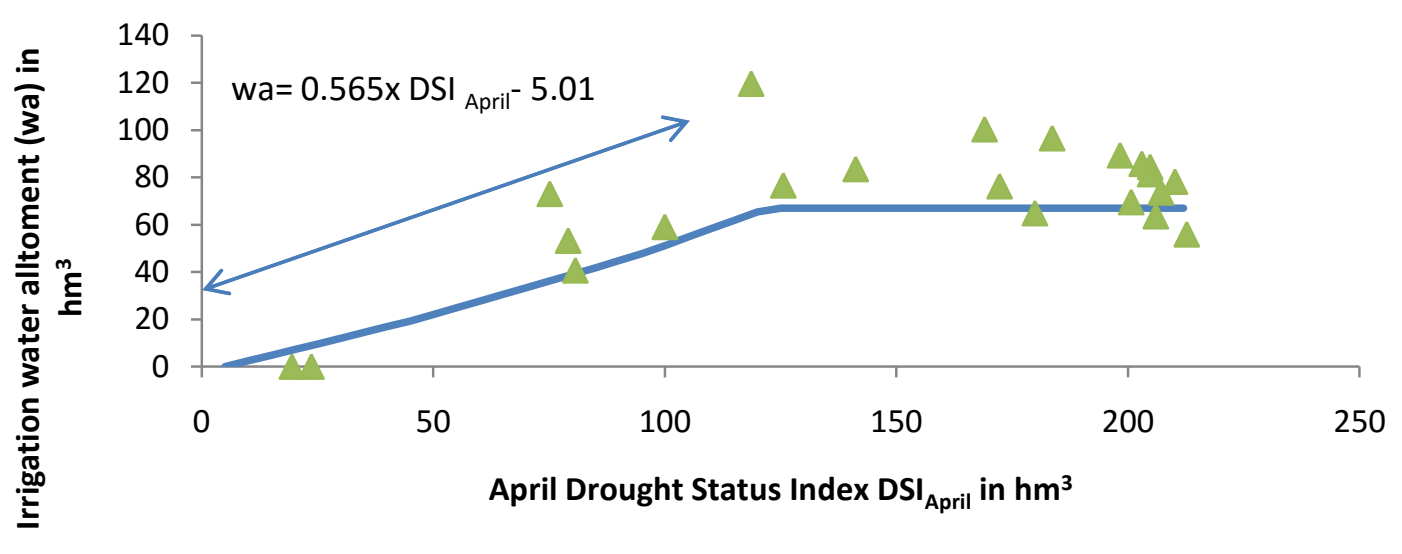

$\triangle$ Actual water releases $\quad$ DMP Guidelines

Figure 4.1. Drought Management Plan Guidelines superimposed on actual water allotments in El Viar Irrigation District (1990-2012)

El Viar is an inertial water supply system. There is a significant correlation of $0.55(\mathrm{p}<0.001)$ between El Pintado stocks in October, which is the beginning of the crop season, and El Pintado stocks in April $\left(D S I_{A p r}\right)$, which is the index that determines water releases from El Pintado based on DMP guidelines. Water shortages can be then forecasted at the beginning of the crop season. Figure 4.2 shows the correlation coefficient between reserves in El Pintado in April and reserves in El Pintado 1 to 18 months in advance. The correlation is no longer significant (i.e., the system losses its memory) 17-18 months in advance from the beginning of the irrigation season (April) considering a degree of significance of $90 \%$. For a degree of significance of $99 \%$, water allotments cannot be forecasted 15 months in advance.

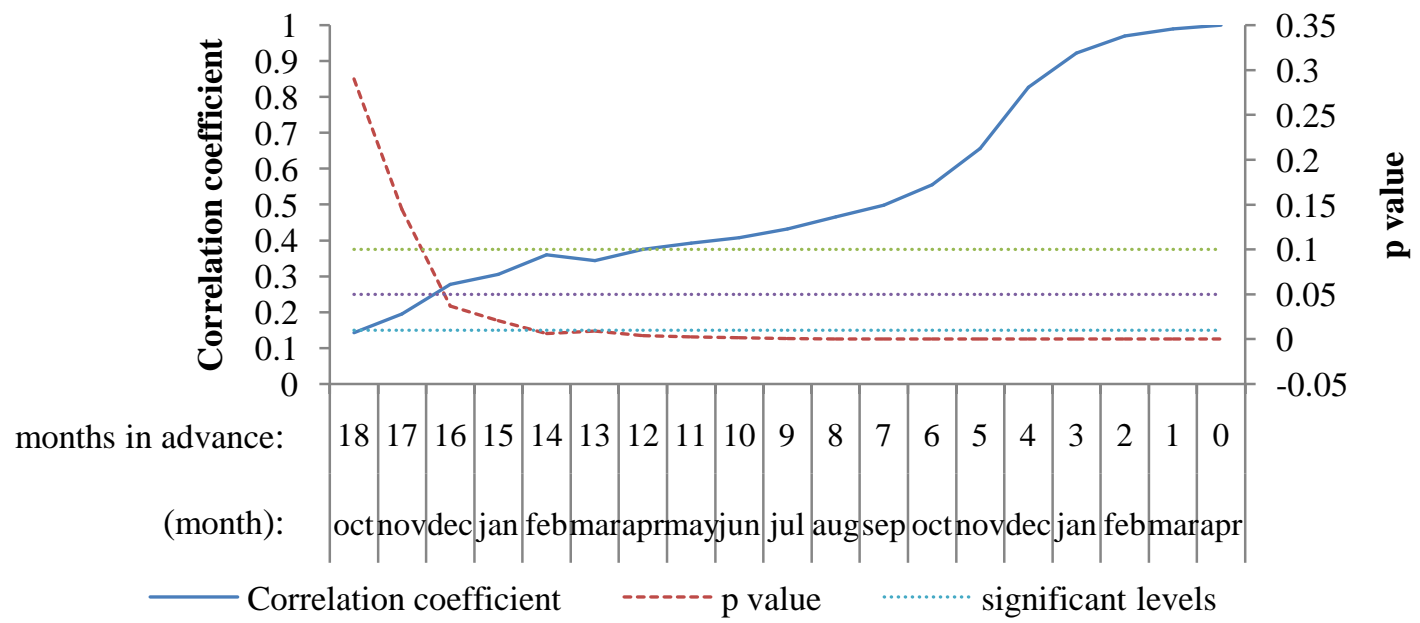

Figure 4.2. Correlation coefficient and degree of significance between April reserves in El Pintado $\left(D S I_{A p r}\right)$ and reserves in El Pintado 1, 2, 3, up to 18 months in advance (1953-2012) 
The index insurance scheme proposed for El Viar is based on an institutional rule: it is based on the $D S I_{A p r}$ and on the DMP Guidelines. Water allotments are estimated from the stocks in El Pintado Reservoir at the end of April, following the line shown in Figure 4.1. The scheme guarantees a water allotment $(w a)$ of $67 \mathrm{hm}^{3}$, which is equivalent to an allocation of 5583 $\mathrm{m}^{3} /$ ha/year.

Note that April reserves $\left(D S I_{A p r}\right)$, on which the indemnity will be calculated, can be easily manipulated by modifying the reservoir releases in the preceding weeks or months, so it is necessary to find another non-manipulable index which can predict the $D S I_{\text {April }}$. The selected predictor or auxiliary index $(A u x I)$ is the sum of the reserves at the end of April of the previous year, plus the accumulated 12-month inflows from May to the following April (equation 4.13). Data for the calculation of the AuxI is available as Supporting Information. Above a threshold the reservoir reaches a maximum level. The threshold has been determined analytically from past records of reservoir stocks and $A u x I$ values, and is equal to 300. The relationship between $D S I_{A p r i l}$ and AuxI has been calculated calculated with historical data ranging from 1953-2012 and the $\mathrm{R}^{2}$ was equal to 0.77 (equation 4.14). Correlation between the estimated $\widehat{D I_{A p r}}$ and the actual $D S I_{A p r}$ is equal to 0.81 .

$$
\begin{aligned}
& \operatorname{AuxI}_{t}=\text { Stocks }_{\text {April } \mathrm{t}-1}+\sum_{m=\text { May } \mathrm{t}-1}^{m=\text { Apr } t} \text { inflows }_{m} \\
& \overline{D S I_{\text {Apr }}}=-22.67+0.685 \times \operatorname{Max}\left(300, \text { Aux } I_{t}\right)
\end{aligned}
$$

Premium rates have been calculated from the estimated $\widehat{D S I_{A p r}}$, considering data series 1953 2012. Data series present non significant trend, so no detrending procedure has been applied. We have considered a franchise deductible $\gamma$ of $30 \%$.

The unitary indemnity applied in our case study is based on the literature. Berbel et al. (2011) estimate the water value in the Guadalquivir River Basin in the year 2005 (see Table 4.1). The average crop surface distribution in El Viar in the period 2002-2008 (data provided by El Viar Irrigation District), would provide a weighted average $€ 0.23$ per cubic meter.

As mentioned in the theoretical framework, when applying the residual value method as the unitary indemnity, it is necessary to subtract the water price. In our case study, it is not necessary, as farmers are paying the water per ha and not per $\mathrm{m}^{3}$ in the period analyzed. It is important to recall that the indemnity covers the fixed irrigation costs. 
Table 4.1. Residual water value per crop in Guadalquivir river Basin (2005) and 5-year-average crop surface (2008-2012) in El Viar Irrigation District (VID)

\begin{tabular}{lcc}
\hline Crop & Residual water value method & El Viar crop surface \\
$€ / \mathrm{m}^{3}$ & ha \\
\hline citrus & 0.344 & 4220.2 \\
olive tree & 0.548 & 117.4 \\
sugar beet & 0.057 & - \\
cotton & 0.257 & 1908 \\
wheat & 0.083 & 298 \\
maize & 0.07 & 3119.6 \\
rice & 0.043 & - \\
sunflower & 0.04 & 338.4 \\
garlic & - & - \\
Region & Guadalquivir River Basin & VID \\
Reference & Berbel et al. (2011) & VID staff \\
Time period & 2005 & $2008-2012$ \\
\hline
\end{tabular}

(i) Premium rates depending on a pre-season index

The use of a pre-season index (PSI) adapts the premium rate to the undertaken risk at the moment of the insurance purchase. The policy purchase period is set in October, corresponding to the beginning of the crop season. The selected pre-season index or PSI is the drought status index measured in October defined in the DMP, which stands for the October reserves in El Pintado Reservoir. DMP defines four different drought statuses: Normality, Pre-Alert, Alert and Emergency. In the same way, our PSI differentiated these 4 risk layers or pre-season scenarios, based on the thresholds established at the DMP (CHG 2007).

We found (see Table 4.2) that premium rates differ greatly depending on the pre-season scenario. Premium rates calculated from $D S I_{A p r}$ oscillate between 0 and $€ 525$ per ha (or $0 \%$ and $40.9 \%$ in percentage of the liability).

One possibility for reducing the premium rate in years in which PSI is in Emergency or in Alert is to allow for contracting a multi-year policy, but the price would still be dependent on the preseason scenario at the moment of the policy purchase. Contracting a 3-year policy, premium rates would oscillate between 75 and $€ 329$ per ha (or $5.8 \%$ and $25.6 \%$ in percentage of the liability) (Table 4.2).

Figure 4.3 shows the evolution of premium rates depending on the number of years and depending on the pre-season scenario at the moment of the policy purchase. In our case study 
we observe that even with a 15-year policy, premium rates are still dependent on the pre-season index, highlighting the strong inertial behavior of the water supply system analyzed.

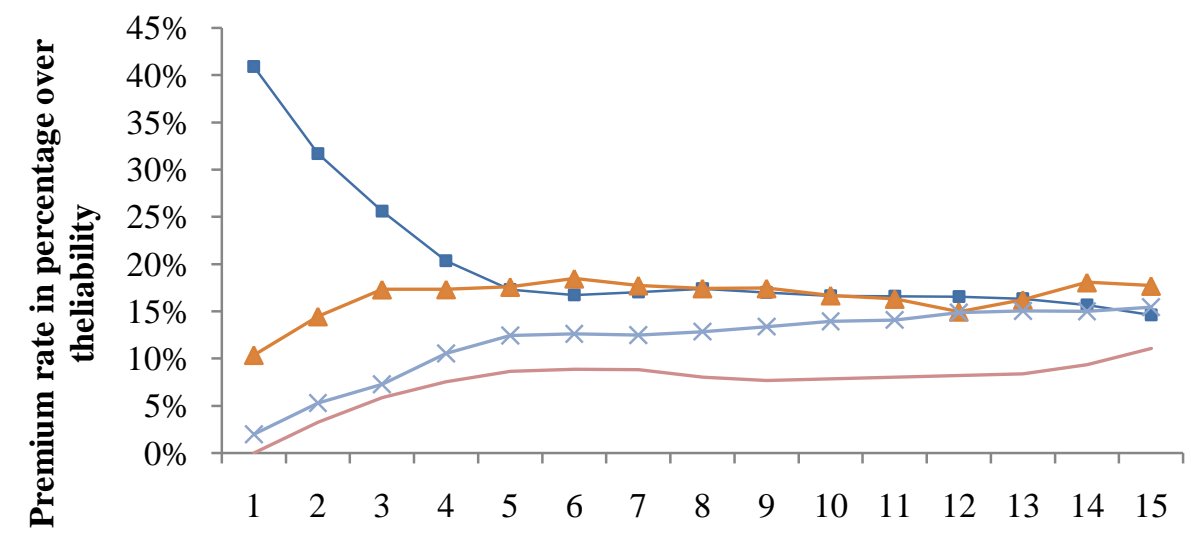

Number of years of the insurance policy

$\rightarrow$ Emergency $\leftarrow$ Alert $\rightarrow$ Pre-alert $\longrightarrow$ Normality

Figure 4.3. Premium rates in percentage over the liability depending on the drought status of the preseason index (Emergency, Alert, Pre-alert or Normality) and depending on the number of years of the insurance policy (1953-2012)

(ii) Early-bird contract with a constant premium rate

The premium paid for an early-bird contract, in which the probability of drought is unknown, is $€ 165$ per ha per year or $12.8 \%$ in percentage of the liability (see Table 4.2). This type of contract should be purchased 17-18 months in advance from the irrigation season (in OctoberNovember of the previous hydrological year), which is the period of time in which the system loses its 'memory' and the probability of drought is unknown (see Figure 4.2).

Table 4.2. Index insurance liability (in $\mathrm{m}^{3} /$ ha and in $€ /$ ha/year) and premium rating in El Viar with a franchise deductible of $30 \%$ for a 1-year policy and for a 3-year policy (in \% over the liability and in $€ /$ ha/year) depending on the type of contract: using a pre-season index contract or an Early-bird contract.

Pre-season index contract premium rate varies depending on the drought status when buying the insurance (Normality / Pre-alert / Alert / Emergency). Premium rates are calculated as the expected indemnity in the period 1953-2012

\begin{tabular}{|c|c|c|c|c|c|c|c|}
\hline \multirow{2}{*}{\multicolumn{2}{|c|}{ Type of contract }} & \multicolumn{2}{|c|}{ Liability } & \multicolumn{2}{|c|}{ Premium 1-year contract } & \multicolumn{2}{|c|}{ Premium 3-year contract } \\
\hline & & $\mathrm{m}^{3} / \mathrm{ha}$ & $€ /$ ha/year & $\%$ (liability) & $€ /$ ha/year & $\begin{array}{c}\% \\
\text { (liability) }\end{array}$ & $€ /$ ha/year \\
\hline \multirow[b]{2}{*}{$\begin{array}{l}\text { Pre-season } \\
\text { index } \\
\text { contracts }\end{array}$} & Normality & \multirow{3}{*}{5583} & \multirow{3}{*}{1284.17} & 0 & 0 & 5.8 & 74.89 \\
\hline & $\begin{array}{c}\text { Pre-alert } \\
\text { Alert } \\
\text { Emergency }\end{array}$ & & & $\begin{array}{c}--\frac{2}{10.4} \\
--\frac{-}{40.9}\end{array}$ & $-\frac{25.52}{133.16}-$ & $-\frac{7.3}{17.3}=$ & $\begin{array}{c}93.65 \\
-222.28 \\
-328.72\end{array}$ \\
\hline \multicolumn{2}{|c|}{ Early-bird contract } & & & 12.8 & 165.05 & 12.8 & 165.05 \\
\hline
\end{tabular}


Basis risk

Water allotments from 1990 to 2012 have been used to calculate de basis risk (basis loss and basis gain) of the index insurance schemes. Given that the index insurance is based on an institutional rule, we can additionally estimate the institutional risk of the index insurance as the difference between the indemnities calculated using directly $D S I_{A p r}$ and the indemnities calculated from the actual water allotments. Institutional risk comes from the institutional uncertainty in applying the rule for the water distribution. There is another source of basis risk not specified in the Theoretical framework, produced by the use of the auxiliary index (AuxI) to estimate the $D S I_{A p r}$ in order to reduce the risk of index manipulation. Delving into this trade-off between basis risk and risk of index manipulation should provide valuable information for agricultural policy design. It is interesting to observe how basis risk is distributed. Ideally 'basis loss' and 'basis gain' should be similar, so the insurance scheme is favoring neither the farmer nor the insurance company. In our case study, total basis risk in the period of study is favoring slightly the insurance company (see Table 4.3).

Table 4.3. Basis risk (1990-2012) divided in Basis loss and Basis gain in El Viar expressed in percentage terms of total liability. Total Basis risk is disaggregated in Institutional risk, and in Basis risk from using AuxI

\begin{tabular}{cccccc}
\hline \multicolumn{2}{c}{ Institutional risk } & \multicolumn{2}{c}{ Basis risk from using AuxI } & \multicolumn{2}{c}{ Total Basis risk } \\
\hline Basis loss $\%$ & Basis gain $\%$ & Basis loss $\%$ & Basis gain $\%$ & Basis loss $\%$ & Basis gain \% \\
\hline 2.2 & 3.4 & 1.5 & 0.2 & 3.7 & 3.6 \\
\hline
\end{tabular}

We observe that the institutional risk is the predominant basis risk in our insurance scheme. In order to further analyze the institutional risk, the differences in actual water allotments received by farmers and water allotments estimated from the institutional rule are shown in Figure 4.4. Note that the institutional rule sets the minimum water releases from the Pintado reservoir, so it is not shocking that actual water allotments are bigger than water allotments from the index insurance. This is why basis gain is larger than basis loss in the institutional risk (see Table 4.3). Years in which the insurance scheme is not covering the actual losses by the farmers are 1993, 1995, 2006 and 2010. The 1993-95 extreme drought in El Viar led to a series of negotiations of water rights transfers between the VID and the society managing the urban water supply in the city of Seville (EMASESA). Given that in 1993, the two parties failed to reach agreement on water rights transfer from El Viar to Seville, most water stocks remained in the El Pintado Reservoir, and no water was allocated to VID. Agreement was finally reached in July 1994, and $30 \mathrm{hm}^{3}$ were assigned to Seville urban users from July to December 1994 (Del Moral 1998). 


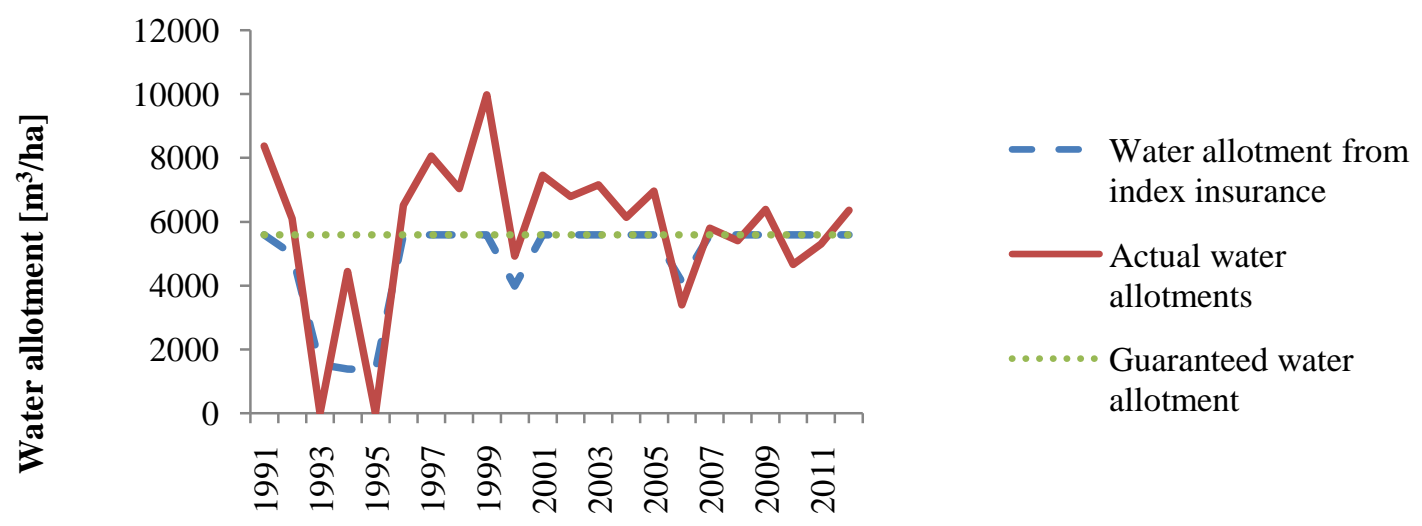

Figure 4.4. Comparison between actual water allotments in El Viar and water allotments estimated from index insurance in the period 1990-2012

\subsection{Discussion}

In this article we presented several insurance schemes to deal with intertemporal adverse selection in hydrological drought index insurance. The methodology has been tested in a water supply system which presents a strong inertial behavior. Figure 4.5 shows the timeline of the hydrological drought index insurance in El Viar.

\section{EI Viar HDII timeline}

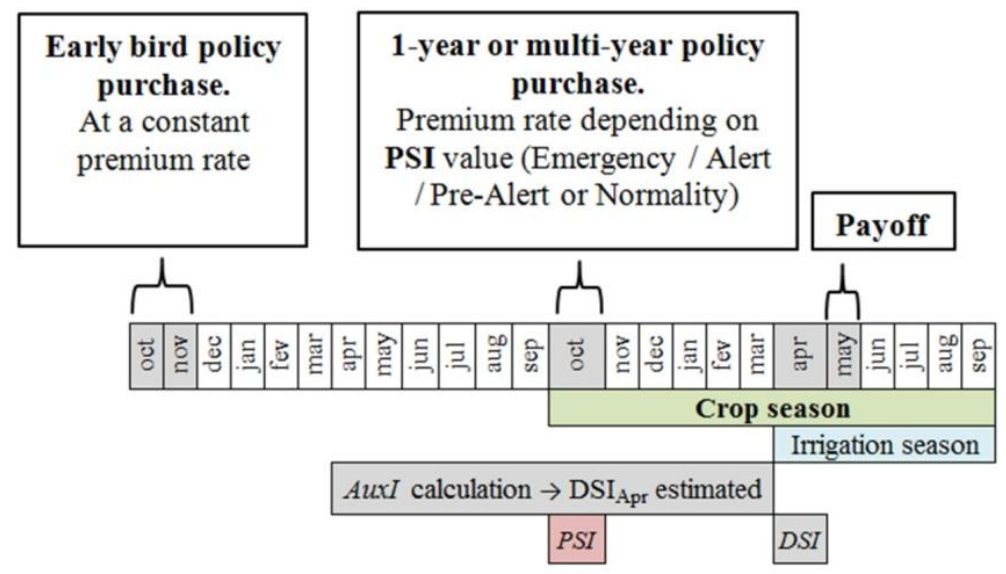

Figure 4.5. El Viar hydrological drought index insurance timeline

The timeline shows chronologically: the time of the year in which the insurance policy should be underwritten (early-bird or PSI contracts), the time of the year in which drought indicators (PSI, DSI and AuxI) are measured, and the time in which irrigators may received the insurance indemnity when applicable. One of the strengths of the insurance scheme in El Viar is that 
farmers receive the economic compensation in May, far before the end of the crop season, allowing them to have ready cash for any eventuality arising in the crop season, such as the possibility of participating in water market mechanisms. This early payoff might be attractive to farmers.

The strong inertial behavior of El Viar system makes premium rates very high when water shortages are predicted at the time of purchasing the insurance policy. The use of multi-year contracts does not even help decreasing the premium rate to affordable prices. Buying a 3-year contract when the water supply system is at alert or emergency status would cost to the farmer $17.3 \%$ or $25.6 \%$ (in percentage of the liability) respectively. This makes water shortage hardly insurable, unless the irrigator purchases an early-bird contact. Early-bird contracts seem the best option for these types of systems. However, premium rates in this study case are still high (12.8 $\%$ of the liability).

The problem of an early-bird contract is the fact that farmers may not be willing to pay the premium rate one year in advance. One suggestion to overcome this issue is to link the earlybird contract purchase to an option contract with the insurance company. The option contract is to be underwritten during the early-bird insurance policy purchase period. At that moment, the farmer pays just a percentage of the premium rate (option contract rating should need further research). When the beginning of the crop season comes, the option contract buyer might (i) purchase the insurance policy paying the premium rate remaining, or (ii) not purchase the insurance policy and lose the contribution. As an alternative to this option contract - insurance policy mechanism, farmers may just sign the policy contract in advance and link the premium rate payment to the CAP subsidies, so that farmers do not have to anticipate the amount of money. The potential demand of early-bird contracts needs further research.

Although institutional rules are quite common in Mediterranean countries where drought is a vital issue, not all water supply systems apply or have an institutional rule. In the case a water supply system lacks an institutional rule, a drought index that represents water availability should be selected, ideally based on natural streamflows (in non regulated sections). Function $f$ in equation 4.1 would be estimated then empirically, from historical data, and should not be subject of manipulation. The Guaranteed Water Allotment (GWA) would be the expected water allotment calculated from historical data. In both cases, whether the index insurance is based on an institutional rule or based on a selected drought index, basis risk of the index insurance should be calculated in order to assess the feasibility of the insurance scheme. Besides, in case the assumption of stationarity of drought indices or institutional rules does not hold, it would be necessary to update the premium rate, so it accurately represents the actual risk undertaken. This would stimulate the purchase of multi-year policies. 
In this research we have identified several sources of basis risk, one coming from the application of the institutional rule, and the other coming from the use of an auxiliary index in order to reduce the risk of index manipulation. Basis risk should be monitored over time to ensure that it remains a manageable risk. A high basis loss would dissuade farmers from buying the insurance. A high basis gain would make insurers to reconsider the viability of the index insurance scheme.

In our case study, the main basis risk comes from the institutional uncertainty in applying the water distribution rules (i.e., institutional risk). In order to implement this type of index insurance schemes, institutional rules or water distribution rules may be consistent and should remain constant over the guarantee period of the contract. Nevertheless, too rigid institutional rules might not be advisable to manage droughts. Droughts are difficult to characterize by means of drought indicators, because you can never have the same drought twice. Each drought should be addressed in a different way as there are a lot of factors taking place (e.g., social, environmental, economic, etc.). In consequence, flexibility on the application of water distribution rules might seem desirable. This flexibility is transformed on institutional risk of the index insurance and we would benefit from further study of this trade-off.

For simplicity, in this article we have considered a constant unitary indemnity based on the literature (established at $€ 0.23$ in all cases and all periods). Other authors have estimated water value in the Guadalquivir River Basin. Lorite et al. (2012), estimate the productivity of water as the revenue under irrigation (irrigated yield times the price of the product) minus the revenue under rainfed conditions (rainfed yield times the price of the product), minus the variable costs of irrigation, per unit of irrigation water applied. Using this method, called Irrigation Water Benefit, the insurance scheme would compensate besides the decrease in productivity and irrigation fixed costs, the extra cost for planting irrigated crops instead of rainfed crops (variable irrigation costs are not compensated). Lorite et al. (2012) estimate the irrigation Water Benefit for olive tree, sugar beet, cotton, wheat, maize, sunflower, and garlic in Genil-Cabra Irrigation district, situated in Guadalquivir River Basin for the period 2002-2007. Water value for citrus fruits (main crop in VID) is not estimated. Weighted water value considering Lorite et al. (2012) results (without considering citrus fruits) is equal to $€ 0.24$ per cubic meter. Although not including citrus fruits, we observe that the weighted value is larger than considering Berbel et al. (2011) results. This is due to the fact that Lorite et al. (2012) compensate the extra cost for planting irrigated crops instead of rainfed crops. It is interesting for the policy holder to be compensated for the extra cost for planting irrigated crops instead of rainfed crops when drought is not anticipated at the beginning of the crop season. 
Although we have considered a constant unitary indemnity to be applied in all cases and all periods, the marginal value of water increases with its scarcity. Curiel (2012) reports that during the 1993-94 drought, El Viar irrigators made more money than usual. The reason was that cotton and peach prices increase that took place due to the low cotton and peach production in the region.

It could be interesting to offer a flexible insurance contract, so that the premium is recalculated according to three variables: (a) the time of the year in which the insurance is purchased, (b) the hydrological status when purchasing the insurance policy, and (c) the number of years that the irrigator would be insured under the same policy. And unitary indemnity would be dependent on (1) hydrological conditions at the beginning of the crop season, and (2) water deficit suffered in the farm.

The schemes described can be applied to other irrigated regions in the world, provided they comply with the following characteristics: (1) There must exist a significant relationship between an indicator (in which the index insurance is based) and water allocations to irrigated agriculture; (2) Ideally, water supply in the Irrigation District comes from a reservoir or a reservoir system situated in the headwaters, where inflows do not depend on human actions, but only on weather conditions. Otherwise, the drought indicator should be selected carefully in order to be objective; (3) The purpose of the reservoir or reservoir system purpose that supplies the water to the irrigation district, should be used mainly for irrigation; (4) Water is distributed equally among the farmers in the Irrigation district. In the case it does not, the policy holder should be the whole Irrigation District (ID). In this case, the ID (actual policy holder), assembles all irrigators that irrigate their farm from the same water source. The ID distributes water, the premium share and the economic compensation between the farmers in order to optimize water productivity in the whole ID. The sharing rule shall be signed by every member of the ID.

\subsection{Summary and conclusions}

The goal of this work was to propose an instrument to reduce the economic impact of water supply shortages on irrigated farms. Water markets and weather derivatives can be used for the same purpose, but they are entirely different instruments. The advantage of an insurance policy is that it can be integrated as an extra coverage in the existing crop insurance schemes and be complementary to water markets. As mentioned in the introduction, there is a high risk of moral hazard associated to irrigation practice in the farm but it can be avoided using index insurance. 
Index insurance covering drought losses in irrigated agriculture has been designed before. However, we proposed different variants meant to deal with inter-temporal adverse selection coming from the possibility of the insured to forecast the water allotment based on hydrological variables at the beginning of the crop season (i.e., in inertial water supply systems). The insurance scheme compensates for reduced irrigation water delivery, paying a unitary indemnity per unit of water deficit. The unitary indemnity is meant to compensate the loss of profit due exclusively to the water shortage.

If the farmer is able to anticipate a situation of reduced water deliveries when buying the insurance policy, a pre-season index indicating the hydrological status of the water supply system can be used to adapt the premium rate to the drought expectations and to avoid adverse selection. Multi-year contracts may average-out the resultant premium rates. If the farmer buys the insurance early enough to be unable to predict whether there will be drought or not, the policy may be purchased at a constant premium with the early-bird contract. Early-bird contracts are recommended in water supply system presenting a strong inertial behavior and might be more effective in terms of reducing farmer's income variability in these conditions.

The application of the methodology could be extended to other irrigated areas in order to study the implications of different degrees of inertia. Implications of the way of managing water (i.e., institutional rules implementation) on the index insurance performance, particularly on basis risk, needs from further analysis. Different schemes presented could be applied as well to other insurance schemes presenting intertemporal adverse selection linked to weather events that might be forecasted in advance (e.g., El Niño event).

The possibilities and difficulties for reinsuring hydrological drought index insurance for irrigated agriculture should be explored. In particular, since droughts can affect an entire basin or even various basins, insuring water shortages can become problematic unless it can rely on a strong risk pooling system. 



\section{DROUGHT INDEX INSURANCE FOR THE CENTRAL VALLEY PROJECT IN CALIFORNIA}

In this Chapter the insurance scheme is adapted to another region suffering from severe hydrological drought episodes. The case study presents inertial behavior. Therefore the insurance schemes presented in Chapter 4 are implemented and a new insurance scheme is proposed.

Publication: Maestro T, Barnett B, Coble K, Garrido A, Bielza M (2016) Drought Index Insurance for the Central Valley Project in California. Applied Economics Perspectives and Policy. doi: 10.1093/aepp/ppw013

\subsection{Abstract}

A multi-year drought has taken a severe toll on the agricultural economy of California's Central Valley. Index insurance is an instrument with potential to protect water users from economic losses due to periodic water shortages. An index insurance product based on the Sacramento Index and adapted to the Central Valley Project water supply is proposed. To address the potential for intertemporal adverse selection, three product designs are suggested. The performance of the designs is assessed using loss functions from the Westlands Water District in the San Joaquin Valley.

\subsection{Introduction}

For more than 50 years California's Central Valley has been one of the most productive agricultural regions of the world, despite receiving rather limited rainfall (Griffin and Anchukaitis 2014). This is due, in large part, to irrigation water provided through an extensive network of interconnected reservoirs, aquifers, rivers, and aqueducts, linking the two major river systems in the Central Valley: the Sacramento River in the North, and the San Joaquin River in the South (see Figure 5.1). Water users in most of the state have access to a wide portfolio of water sources, including water transfers, surface storage, groundwater banking, and water marketing, reducing the vulnerability of irrigated agriculture to water scarcity situations (Hanak et al. 2011; Mukherjee and Schwabe 2015). There are two surface water supply infrastructures (the largest in California) that store and convey the water in the Sacramento-San Joaquin River 
Basin: the Central Valley Project (CVP), financed by the Federal Government, and the State Water Project (SWP), financed by the state of California.

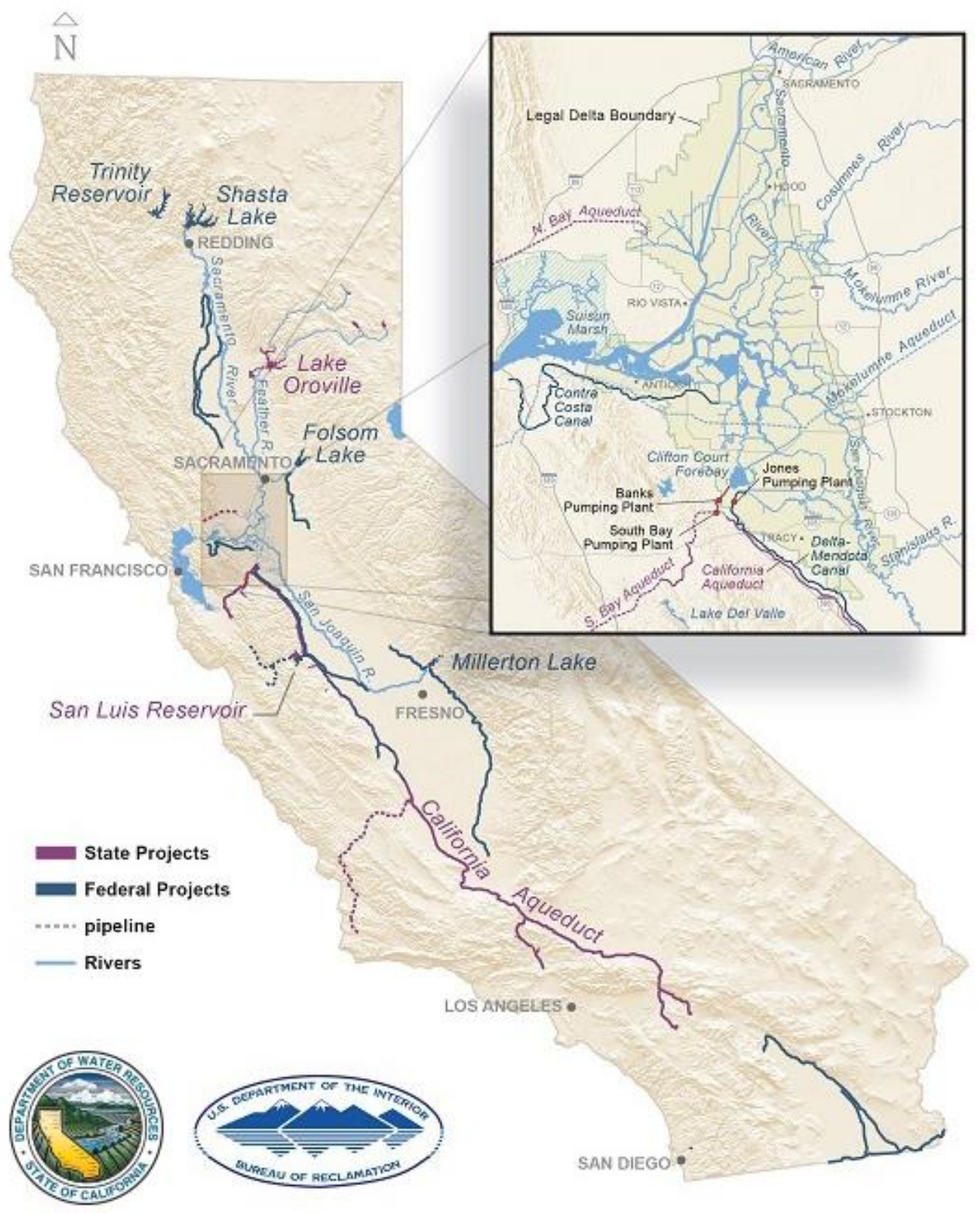

Figure 5.1. Geographic extent and general location of SWP and CVP facilities in Central Valley in California. Source: California Department of Water Resources and United States Bureau of Reclamation (2014)

Despite the continuous efforts to increase efficiency and water reliability, California remains vulnerable to water scarcity problems. Prior to the winter of 2015-2016, California experienced three years of severe drought (Howitt et al. 2014). In fact, a recent study based on paleoclimate reconstructions of drought and precipitation in Central and Southern California found that the period 2012-2014 was the most severe drought experienced in the region over the last 1,200 
years (Griffin and Anchukaitis 2014). This drought caused the loss of billions of dollars and thousands of seasonal and part-time jobs (Howitt et al. 2014).

This study examines the potential for landowners and farmers who receive irrigation water from the CVP to use an index insurance product to protect themselves from the financial implications of reduced water allocations. Specifically, scenarios are considered where reduced water allocations force landowners to leave some land fallow and farmers to experience increased costs associated with pumping groundwater for irrigation.

Various Multiple Peril Crop Insurance (MPCI) products are available for many of the crops produced in the Central Valley. For crops insured under an irrigated practice, these MPCI products provide coverage for yield losses due to a failure of irrigation water supply. However, farmers can insure under an irrigated practice only the acreage that would be fully irrigated considering the expected water availability at the beginning of the crop season (when insurance attaches). The expected water availability is based on water available in reservoirs, soil moisture levels, snow pack storage levels (if applicable), and precipitation which would normally be received during the crop season. To be covered by MPCI, any failure in irrigation water supply must be due to a naturally occurring event. Decreased water allocations due to a diversion of water for environmental reasons, compact compliance, or other non-naturally occurring causes are not covered (RMA-Topeka 2015).

Farm-level MPCI that includes coverage for irrigation water shortages can be difficult to implement due to asymmetrically distributed information. Insured farmers' proprietary knowledge of irrigation practices used on the farm leave the insurer vulnerable to moral hazard and adverse selection. To address asymmetric information concerns, an index insurance product is proposed that would cover the risk of water shortages. The product is also explicitly designed to cover shortages due to the diversion of water for environmental purposes - a major source of water supply risk that is not covered by existing MPCI products.

Compared to MPCI, index insurance is less vulnerable to moral hazard and adverse selection, is less expensive to administer, and is easier to reinsure because contracts are more transparent (Miranda and Farrin 2012). Unlike MPCI which makes payments based on actual losses experienced by the insured, index insurance indemnifies the insured based on the observed value of a specified index. Ideally, an index is a random variable that is objectively observable, reliably measurable, and highly correlated with the losses of the insured, and cannot be influenced by the actions of the insured (Miranda and Farrin 2012). Examples that are well documented in the literature include area-yield (or revenue) index insurance in which indemnities are paid based on a shortfall in area average yield (or revenue) (Miranda 1991; Skees et al. 1997; Mahul 1999; Coble and Barnett 2008) and weather index insurance (Martin et 
al. 2001; Turvey 2001; Vedenov and Barnett 2004; Barnett and Mahul 2007; Collier et al. 2009; Collier et al. 2011; North et al. 2013; Ritter et al. 2014).With weather index insurance, indemnities are paid based on realizations of an underlying index measured over a pre-specified period of time at a particular point of measurement. The underlying index triggering the indemnity might be a weather parameter such as rainfall or temperature, but it may also be an indirect measure of weather conditions such as a hydrologic variable (e.g., river flows or snow pack), a satellite-measured vegetation index, or an El Niño-Southern Oscillation index. The principal challenge in designing index insurance is to find an index that fulfills the quality standards of the insurance industry (i.e., objectivity, reliability, transparency), correlates well with the insured losses, and generates sufficient demand (Collier et al. 2009). Underlying indices generally must be carefully selected or designed for each index insurance product (Vedenov and Barnett 2004).

Weather index insurance pilot projects have been implemented in many developing countries (Skees et al. 2001; Barnett and Mahul 2007; Bielza et al. 2008; Barnett et al. 2008; Collier et al. 2009; Mahul and Stutley 2010; Miranda and Farrin 2012) but are feasible in developed countries as well. Previous studies demonstrate the potential for weather index insurance to cover water supply risks using a rainfall index (Zeuli and Skees 2005; Buchholz and Musshoff 2014) or streamflow indices (Brown and Carriquiry 2007; Leiva and Skees 2008; Zeff and Characklis 2013). However, to our knowledge no previous studies have focused on using index insurance to protect against water supply risks in California's Central Valley.

One major disadvantage of index insurance is basis risk, which is variability in the relationship between the value of losses as measured by the index and the value of losses actually experienced by the insured. Due to basis risk, it is possible for the insured to suffer a loss and yet not receive an indemnity (Barnett 2004; Skees, Barnett and Collier 2008; Collier et al. 2009; Miranda and Farrin 2012). Likewise, it is possible for the insured to receive an indemnity when no loss has occurred.

In the Central Valley of California, water is supplied by both the CVP and the SWP. However, water deliveries from the CVP are more variable than those of the SWP (Mukherjee and Schwabe 2015). Therefore, our study focuses on the CVP. Initial construction of the CVP began in October 1937. Today the CVP consists of 22 reservoirs that can store 11 million acre-feet of water. In an average year, 7 million acre-feet are delivered, irrigating more than 3 million acres of farmland and providing drinking water to nearly 2 million consumers (California Department of Water Resources 2015b). An index insurance product is proposed that is adapted to the CVP water supply and provides economic compensation to landowners and farmers in years of surface water shortages. The insurance can be used to reduce variability in income and/or costs. 


\subsection{Water management in the Central Valley of California}

Surface water in the Central Valley of California flows through a network of canals and reservoirs that allows water to be transported from the more humid North (Sacramento Valley) to the drier South (San Joaquin Valley), where most of the irrigation demand is located. Two pumping stations, the C.W. Bill Jones (Tracy) Pumping Plant, operated by the CVP, and the Banks Pumping Plant operated by the SWP (see Figure 5.1), pump and divert water from the Delta (confluence of Sacramento and San Joaquin rivers) to the San Joaquin Valley. This water redistribution from North to South affects the water ecosystem, and concerns have been raised about maintaining sufficient surface water flows to support endangered species. Consequently, regulations establish minimum required surface water flows throughout the year and limit the export of water from the Sacramento - San Joaquin Delta. Appendix A.1 presents the primary water management regulations along with the period of implementation. Since 2009, environmental measures have become more stringent, with the implementation of Biological Opinions proposed by the U.S. Fish and Wildlife Service (USBR 2008) and by the National Marine Fisheries Service (National Marine Fisheries Service 2009), setting new salinity and flow requirements.

Groundwater constitutes on average about a third of statewide water use. In contrast to surface water, there are few places (mainly in urbanized areas of Southern California) where users must have permits to withdraw a specific quantity of water. Thus, the right to pump groundwater is currently available to most users overlying the aquifer (Hanak and Stryjewski 2012). However, this is likely to change over time. State legislation adopted in January 2015 requires that local groundwater agencies be established by June 30, 2017. These agencies must develop groundwater management plans by January 31, 2020 for basins in a critical overdraft condition and by January 31, 2022 for all others. The legislation gives these local agencies the power to restrict groundwater pumping, shut down wells, and impose fines and penalties on resistant landowners (Dooley, 2015).

For drought management and environmental protection purposes, the California Department of Water Resources and the United States Bureau of Reclamation use several indices to estimate available surface water supply in the Sacramento Valley (Sacramento Valley 40-30-30 Index) and the San Joaquin Valley (San Joaquin Valley 60-20-20 Index). Since most of the water used in the Central Valley comes from the Sacramento River, the Sacramento Valley 40-30-30 Index (hereafter, the Sacramento Index) is the most widely used to assess drought status for the Central Valley. 


\subsection{Drought Index Insurance for the Central Valley Project in California}

The underlying index used for a water supply index insurance product should be a measure used by water managers for the distribution of water among users, provided it meets the quality standards of the insurance provider. For the CVP, the Sacramento Index is the measure used for water planning and management.

The Sacramento Index was originally specified in the 1995 State Water Resources Control Board (SWRCB) Water Quality Control Plan. It is measured on May 1 each year and determines the water year hydrologic type for the implementation of flow and water quality criteria contained in State Water Board Decision D-1641 and in Biological Opinions (BOs) (see Appendix A.1). The hydrologic classification of a water year provides relative estimates of a basin's available water supply based on the amounts of rainfall, snowmelt runoff, and groundwater accretion rates. Water year types are classified as wet, above normal, below normal, dry, or critical (California State Water Resources Control Board 2000) (see Table 5.1).

Table 5.1. Sacramento Valley 40-30-30 Index (Sacramento Index) Water Year Hydrologic Classifications

\begin{tabular}{ll}
\hline Water Year Type & Sacramento Index value \\
\hline Wet & Equal to or greater than 9.2 \\
Above Normal & Greater than 7.8, and less than 9.2 \\
Below Normal & Greater than 6.5, and equal to or less than 7.8 \\
Dry & Greater than 5.4, and equal to or less than 6.5 \\
Critical & Equal to or less than 5.4 \\
\hline \multicolumn{2}{c}{ Source: California State Water Resources Control Board 2000. }
\end{tabular}

The hydrologic year begins in October. As shown in equation 5.1, the Sacramento Index (Sacramento Valley 40-30-30 Index) in hydrologic year $t$ is composed of three components, weighted as its name suggests $(40 \%, 30 \%, 30 \%)$.

$$
S I_{t}=\left[0.4 * \operatorname{AprJul}_{t}\right]+\left[0.3 * \text { OctMar }_{t}\right]+\left[0.3 * \operatorname{Min}\left(10,\left(S I_{t-1}\right)\right)\right]
$$

where $A p r J u l_{t}$ is the May forecast of runoff for the period April through July in million acrefeet, OctMar $r_{t}$ is the actual unimpaired runoff for the period October through March in million acre-feet, and $S I_{t-1}$ is the Sacramento Index in hydrologic year $t-1$. A cap of 10.0 million acrefeet is put on $S I_{t-1}$ to account for required flood control reservoir releases during wet years. The OctMar $_{t}$ runoff is the sum of unimpaired flow from October through March in hydrologic year $t$ in million acre-feet at: Sacramento River above Bend Bridge; Feather River at Oroville; Yuba River near Smartville; and American River below Folsom Lake. The unimpaired runoff represents the natural water production of the river basin, unaltered by upstream diversions, storage, or export or import of water to or from other watersheds. The natural runoff at a gauge is reconstructed by removing the effects of these "impairments". Unimpaired runoff is 
reconstructed following a methodology that is reported in the "California Central Valley Unimpaired Flow Data" (California Department of Water Resources 2007). Forecasts of runoff between April and July in hydrologic year $t$ are made based on observed precipitation, flows, and snow pack by the California Department of Water Resources. Preliminary forecasts are made in February, March, and April, with the final determination in May.

\subsubsection{Potential for intertemporal adverse selection}

The Sacramento Index has an autoregressive component, which is the Sacramento Index of the previous hydrologic year $\left(S I_{t-1}\right)$. If an insurance product based on the Sacramento Index is purchased at the beginning of the hydrologic year (October), both the policyholder and the insurer would have some information about the value that the Sacramento Index would take in the following May. ${ }^{9}$ This autoregressive component must be addressed to avoid potential policyholders being more (less) likely to purchase the insurance product when the $S I_{t-1}$ is low (high) suggesting that the Sacramento Index in the current year $\left(S I_{t}\right)$ is also likely to be low (high). ${ }^{10}$ To address this potential for intertemporal adverse selection, the insurance sales closing date can be moved prior to the determination of $S I_{t-1}$. Alternatively, once $S I_{t-1}$ is known, the premium rate or deductible may be made conditional on the value of $S I_{t-1}$ (Luo et al. 1994; Carriquiry and Osgood 2012; Ker and McGowan 2015; Osgood et al. 2008).

\subsubsection{CalLite estimates of water deliveries}

Given relatively recent changes in California water management regulations (the last changes were made in 2009), there are insufficient years of actual experience under the current regulatory regime to evaluate whether the Sacramento Index correlates well with actual CVP water deliveries. Therefore, a hydrologic model, known as CalLite, is used for estimating what would have happened in the past if the current regulatory regime had been in place. CalLite was developed by The California Department of Water Resources (DWR) and the U.S. Bureau of Reclamation (California Department of Water Resources and United States Bureau of Reclamation 2011; Islam et al. 2011). It can estimate monthly CVP water deliveries for the period 1922-2003 under different regulatory regimes. Additional information on CalLite can be found in Appendix A.2.

\footnotetext{
${ }^{9}$ Other examples of index insurance products with potential for intertemporal adverse selection include those with indices affected by the onset of El Niño conditions (GlobalAgRisk 2009) or those based on water reserves in a water supply system (Maestro et al. 2016).

${ }^{10}$ In an insurance context, adverse selection occurs when potential policyholders make insurance purchase decisions using information about their risk exposure that it not available (or, at least, not used) by the insurer. Adverse selection typically occurs cross-sectionally as the insurer inadvertently misclassifies the risk exposure of potential policyholders. Those whose risk exposure has been misclassified to their advantage (detriment) are more (less) likely to purchase insurance. However, adverse selection can also occur intertemporally if potential policyholders make purchase decisions using relevant information that is not used by the insurer.
} 
Data on actual monthly CVP water deliveries is available beginning in 1993 (USBR 2015). The irrigation period is from May through September so for each year between 1993 and 2003 the irrigation period actual deliveries were compared to the irrigation period CalLite estimated deliveries. Figure 5.2 clearly shows that the CalLite estimate of deliveries is generally lower than the actual CVP water deliveries for the irrigation period. But most of this difference occurs in years when the actual deliveries are unusually high (e.g., 1995-1997). What is relevant for the proposed insurance product is years when actual deliveries are less than expected. For the seven years when actual deliveries are less than the 11-year average of actual deliveries, the difference between the CalLite estimate and actual deliveries is quite small. Similarly, actual deliveries are clearly more variable than CalLite estimated deliveries over the 11 year period but this difference goes away when one focuses only on the years when actual deliveries are less than the 11-year average. The correlation of the two series over the 11 -year period is 0.79 ( $\mathrm{p}$ value $=$ 0.00). For the seven years when actual deliveries were below the 11-year average, the correlation is $0.76(\mathrm{p}$ value $=0.02$ ). For the three years when actual deliveries were less than 90 percent of the 11-year average, the correlation coefficient was 0.98 ( $\mathrm{p}$ value $=0.06$ ). This suggests that the CalLite estimates are a good proxy for actual CVP water deliveries, especially in years when actual deliveries are low (which is what is relevant for the insurance product).

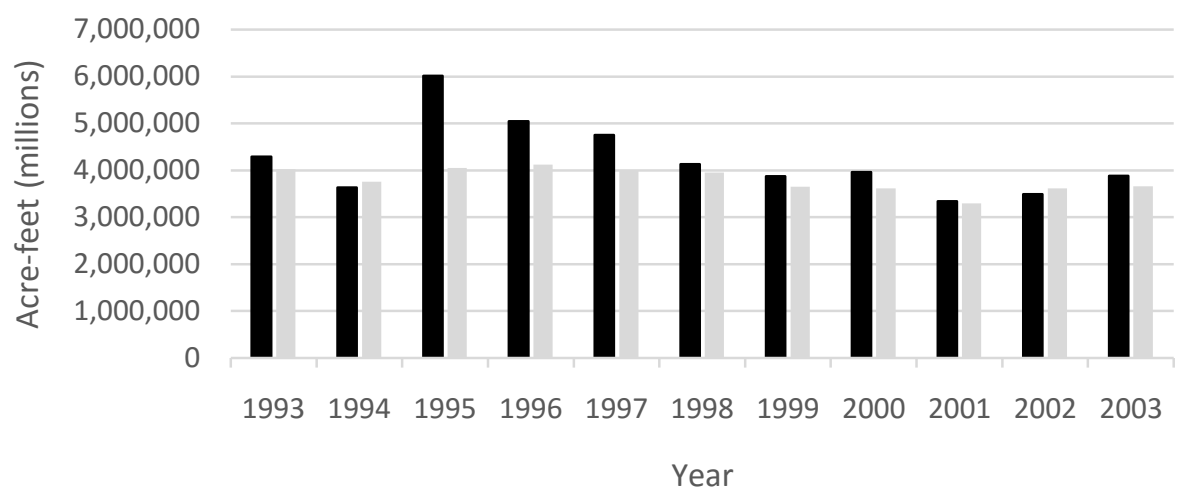

Actual May-Sept CVP Deliveries $\square$ CalLite Estimated May-Sept CVP Deliveries

Figure 5.2. Actual and CalLite estimated CVP water deliveries for May through September irrigation period

Data on the Sacramento Index is available from the California Department of Water Resources (2015a). No statistically significant time trend is observable in the Sacramento Index data from 1922 until 2003, which corresponds to the period for which CalLite can conduct water delivery estimates. The average value of the index over this period was 7.93 , close to the threshold between Above Normal and Below Normal water year hydrologic classifications (see Table 5.1). 
The linear correlation between the Sacramento Index and CalLite estimated CVP annual irrigation period (May-September) water deliveries under the current regulatory regime for the period 1922-2003 is 0.87 ( $\mathrm{p}$ value $=0.00$ ). ${ }^{11}$ Linear and logarithmic models linking the Sacramento Index and CalLite estimated annual water deliveries in thousand acre-feet (TAF) were compared using the Box-Cox transformation ${ }^{12}$, which makes the residual sums of squares directly comparable. The double logarithmic model was selected because it had the smallest residual sum of squares.

$$
\log \text { CalLite Water deliveries }_{t}=\begin{gathered}
7.34^{* * *} \\
(0.048)
\end{gathered}+\log S I_{t} \times \begin{aligned}
& 0.38^{* * *} \\
& (0.023)
\end{aligned} \quad \text { adjusted } \mathrm{R}^{2} 0.76
$$

In equation 5.2 the three asterisks denote statistical significance at the $1 \%$ level. Numbers inside parentheses represent the robust standard errors. Equation 5.2 means that if the Sacramento Index increases by $1 \%$, estimated CVP water deliveries increase by $0.38 \%$. The adjusted $\mathrm{R}^{2}$ indicates that $76 \%$ of the variability in estimated water deliveries is explained by the Sacramento Index however, equation 5.2 it is not sufficient to demonstrate the performance of an index insurance product based on the Sacramento Index because it does not account for how the level of water deliveries translates into economic losses. Thus, empirical analyses of the performance of the proposed index insurance product are presented later.

\subsubsection{Design and rating of Sacramento Index insurance}

The insurance product proposed would provide a payout whenever environmental conditions (as measured by the Sacramento Index) fall below a threshold signaling that water users will not receive their full allocation of water. The payout increases as the Sacramento Index decreases (below the upper threshold). The rate at which the payout increases per unit change of the index is called the "tick" of the contract. The formula for the insurance payout or indemnity $I_{t}$ in year $t$, is shown in equation 5.3:

$$
I_{t}=\left\{\begin{array}{ccc}
0 & \text { if } & S I_{t} \geq U \\
D \times\left(U-S I_{t}\right) & \text { if } & S I_{t}<U
\end{array}\right.
$$

where $S I_{t}$ denotes the Sacramento Index in year $t . U$, the upper trigger of the contract, and $D$, the tick, are both choice variables selected by the purchaser. Liability is equal to $D \times U$ which is the maximum possible payout of the contract.

\footnotetext{
${ }^{11}$ Current regulatory framework simulated in CalLite includes D-1641 and Biological Opinions.

${ }^{12}$ The procedure consists of dividing the observations on the dependent variable by their geometric mean and then regressing the transformed variables, leaving the right side of the equation unchanged. The residual sums of squares are then directly comparable. The specification with the smaller RSS therefore provides the better fit (Zarembka 1968; Spitzer 1984).
} 
The actuarially fair premium $P$ is given by the expected indemnity $\mathrm{E}\left(I_{t}\right)$ and the actuarially fair premium rate in percentage terms is the actuarially fair premium (expected indemnity) divided by the liability.

To develop insurance designs that address the potential for intertemporal adverse selection, it is necessary to determine analytically the expected distribution of the Sacramento Index in year $t$ conditional on the value of the Sacramento Index in year $t-1$. To do this, distributions were fit to each of the components of the Sacramento Index: OctMar period October through March in million acre-feet), AprJul (May forecast of runoff for the period April through July in million acre-feet), and $S I_{t-1}$ (Sacramento Index in hydrologic year $t$ 1). Gamma, Lognormal, Normal, and Weibull distributions were compared using the Kolmogorov-Smirnov (K-S) test (Massey 1951). The K-S test measures how well the distribution fits the input data and how confident one can be that the data could have been produced by the distribution function. The (K-S) statistic is generally preferred over the chisquare statistic because it is not dependent on the set of midpoints used for the histogram (Palisade Corporation 2015). The Gamma distribution was the best fit for both OctMar $_{t}$ and $\operatorname{AprJul}_{t}$ flows. For the lagged Sacramento Index $\left(S I_{t-1}\right)$, the Lognormal distribution was the best fit, followed by the Gamma distribution. Since the Gamma distribution was also a valid fitting for $S I_{t-1}$, it was used for all the components, as shown in Table 5.2. Summary statistics from the distribution fitting procedure can be found in appendix tables A1-A3.

Table 5.2. Distributions fitted to the components of the Sacramento Index in the period 1922-2014 and Sacramento Index conditional distributions for a given value $t$ with Sacramento Index in year $t-1$ equal to $2,4,6,8$, and 10

\begin{tabular}{cccc}
\hline Variable & $\begin{array}{c}\text { Fitted Distribution } \\
\text { Gamma (Threshold } \theta, \text { Scale } \sigma, \text { Shape } \alpha)\end{array}$ & $\begin{array}{c}\text { p value } \\
\text { Kolmogorov- } \\
\text { Smirnov test }\end{array}$ & Expected value \\
\hline Oct-Mar & Gamma $(2.14,3.50,2.25)$ & $>0.25$ & 10.05 \\
Apr-Jul & Gamma $(1.44,2.04,2.49)$ & $>0.5$ & 6.5 \\
SI & Gamma $(1.75,1.17,5.24)$ & $>0.25$ & 7.88 \\
$\mathbf{S I} \mid \mathbf{S I}_{\mathbf{t}-\mathbf{1}}=\mathbf{2}$ & Gamma $(1.69,1.55,2.92)$ & $=0.15$ & 6.22 \\
$\mathbf{S I} \mid \mathbf{S I}_{\mathbf{t}-\mathbf{1}}=\mathbf{4}$ & Gamma $(2.29,1.55,2.92)$ & $=0.15$ & 6.82 \\
$\mathbf{S I} \mid \mathbf{S I}_{\mathbf{t}-\mathbf{1}}=\mathbf{6}$ & Gamma $(2.89,1.55,2.92)$ & $=0.15$ & 7.42 \\
$\mathbf{S I} \mid \mathbf{S I}_{\mathbf{t}-\mathbf{1}}=\mathbf{8}$ & Gamma $(3.49,1.55,2.92)$ & $=0.15$ & 8.02 \\
$\mathbf{S I} \mid \mathbf{S I}_{\mathbf{t}-\mathbf{1}}=\mathbf{1 0}$ & Gamma $(4.09,1.55,2.92)$ & $=0.15$ & 8.62 \\
\hline
\end{tabular}

For a given value of $S I_{t-1}$, stochastic simulation for the other two components was performed using @Risk 7 (Palisade Corporation 2015). The linear correlation between OctMar ${ }_{t}$ and $\operatorname{AprJul}_{t}$ was estimated to be 0.67 (p value $\left.=0.00\right)$ (see Figure A1). The correlation between $S I_{t-1}$ and $O c t M a r_{t}$ was not statistically significant (p value $>0.10$ ) nor was the correlation between $S I_{t-}$ 
$l$ and $\operatorname{AprJul}_{t}(\mathrm{p}$ value $>0.10)$ (see Figure $\mathrm{A} 1$ ). In order to better capture nonlinear dependencies that may exist at the relevant extremes of OctMar $_{t}$ and $A p r J u l_{t}$, copulas were used instead of linear correlations. A copula is a function that combines marginal distributions of variables into a specific multivariate distribution (Collier et al. 2011). Five copula functions were tested using @Risk 7 (Palisade Corporation 2015): Gaussian and t copulas from the family of Elliptical copulas, and Gumbel, Clayton, and Frank copulas from the family of Archimedean copulas. Maximum likelihood estimation (MLE) was used to estimate the parameters of the copula functions. The Akaike Information Criterion (AIC) was used to choose among alternative model specifications. Although it does not provide any absolute measure of goodness-of-fit, AIC does identify that one copula is a better fit than the others (Palisade Corporation 2015). The best fit for the joint behavior of OctMar $_{t}$ and AprJul $t_{t}$ was a Gumbel copula reflected about both axes (GumbelR) with $\theta=2.127$ (see Figure A1).

The conditional distributions of the Sacramento Index in year $t$ for a Sacramento Index value in year $t-1$ equal to 2, 4, 6, 8, and 10 were fit using 5,000 draws from the distributions of OctMar and $\mathrm{AprJul}_{t}$ with the dependence between these variables modeled using a Gumbel copula as described above. Summary statistics from the distribution fitting procedure can be found in appendix tables A4-A8. Not surprisingly, the distributions shift to the right with increasing values of the Sacramento Index in year $t-1$.

Three alternative index insurance designs are proposed to address the potential for intertemporal adverse selection: (1) "early bird" insurance, (2) variable premium insurance, and (3) variable deductible insurance. Figure 5.3 shows the timeline of the insurance product purchase, payoff determination, and other important milestones such as the premium determination for the variable premium design and the deductible determination for the variable deductible design. Early bird insurance would require insurance to be purchased one year before the hydrologic season begins (i.e., October of the previous year). This design has a constant actuarially fair premium rate since no reliable information is yet available to inform expectations of the distribution of the Sacramento Index. 
(1) Sales closing

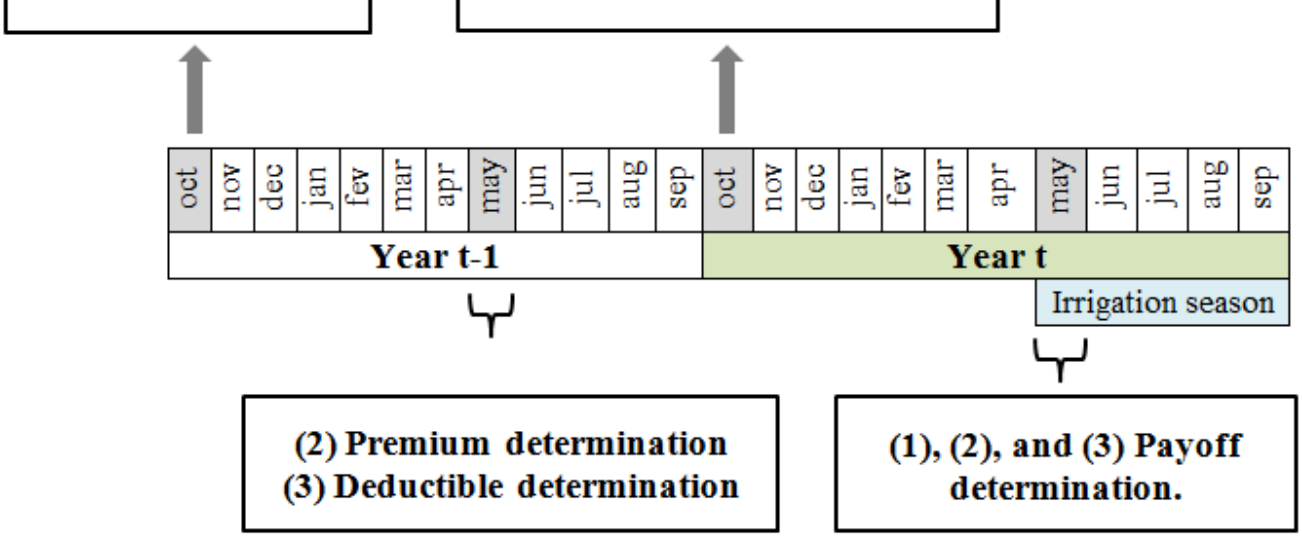

(2) \& (3) Sales closing

(1) Indicates the early bird design, (2) the variable premium design, and (3) the variable deductible design.

Figure 5.3. Timeline for proposed Central Valley Project index insurance designs

If the insurance product is instead purchased after $S I_{t-1}$ has been determined, expectations of the distribution of $S I_{t}$ can be conditioned on the value of the $S I_{t-1}$. In consequence two different designs are proposed to address the potential for intertemporal adverse selection: variable premium insurance utilizes a premium rate that is conditioned on the value of $S I_{t-1}$ and variable deductible insurance utilizes a deductible that is conditioned on the value of $S I_{t-1}$. The purchaser of an insurance product with the variable premium design would be concerned about protecting against shortfalls in $S I_{t}$ relative to an absolute upper threshold $U$ (recognizing that the premium rate will vary with the level of $S I_{t-1}$ ). The purchaser of an insurance product with the variable deductible design would be concerned about protecting only against shortfalls in $S I_{t}$ that could not have been anticipated given the value of $S I_{t-1}$.

For the early bird design, actuarially fair premium rates are shown in Table 5.3. Several levels of the upper threshold are considered. An upper threshold equal to $8(\mathrm{U}=8)$ corresponds to the expected value of the Sacramento Index. Said differently, $\mathrm{U}=8$ provides coverage equal to $100 \%$ of the expected value of the index. Lower values of the upper threshold would provide lower levels of coverage. $\mathrm{U}=7.8$, corresponding to the threshold between Below Normal and Above Normal water year hydrologic classifications (see Table 5.1) provides $97 \%$ coverage. U=7.6 provides $95 \%$ coverage, $\mathrm{U}=7.2$ provides a $90 \%$ coverage and $\mathrm{U}=6.4$ provides $80 \%$ coverage. Actuarially fair premium rates were calculated empirically using historical Sacramento Index data for the period 1922-2014. Premium rates were also calculated through Montecarlo simulation. Five thousand realizations of the Sacramento Index were simulated using the 
gamma distribution fitted to the historic data $(\operatorname{Gamma}(1.75,1.17,5.24)$, see Table 5.2). The premium rates obtained from each method were very similar (see Table 5.3).

Table 5.3. Premium rates for the early bird contract design considering different Sacramento Index thresholds. Premium rates are calculated from historical data (1922-2014) and Montecarlo simulation

\begin{tabular}{ccc}
\hline $\begin{array}{c}\text { Upper } \\
\text { threshold }\end{array}$ & $\begin{array}{c}\text { Premium rate } \\
\text { (historic data) }\end{array}$ & $\begin{array}{c}\text { Premium rate } \\
\text { (Montecarlo simulation*) }\end{array}$ \\
\hline 6.4 & $6.08 \%$ & $6.16 \%$ \\
7.2 & $10.13 \%$ & $9.79 \%$ \\
7.6 & $12.37 \%$ & $11.82 \%$ \\
7.8 & $13.45 \%$ & $12.88 \%$ \\
8 & $14.53 \%$ & $13.96 \%$ \\
\hline \multicolumn{2}{c}{5000 draws from Gamma $(1.75,1.17,5.24)$}
\end{tabular}

For both the variable premium and variable deductible designs, the upper threshold is established at $\mathrm{U}=7.8$ (to the threshold between Below Normal and Above Normal water year hydrologic classifications). For the variable premium design, actuarially fair premium rates are a decreasing function of $S I_{t-1}$. Because of the formula used to calculate the Sacramento Index (see equation 5.1), the actuarially fair premium rate remains constant for values of $S I_{t-1}$ that are greater than or equal to 10 . Equation 5.4 presents the equation for the actuarially fair premium rate based on the relationship between premium rates from their stochastic simulations at different levels of $S I_{t-1}$.

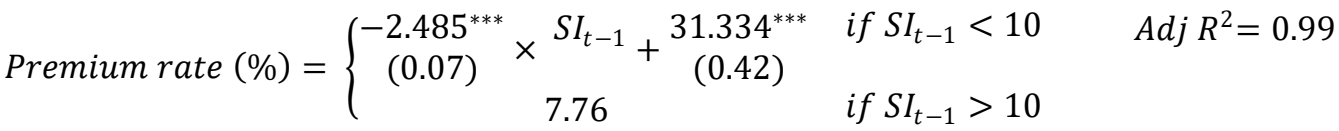

In equation 5.4 asterisks ${ }^{* * *}$ denote significance at $1 \%$ level. Numbers inside parentheses represent the robust standard error.

For the variable deductible design, the premium rate remains constant but the deductible varies conditional on the value of $S I_{t-1}$. The variable conditional deductible would be calculated as shown in equation 5.5 as the difference between the maximum expected Sacramento Index in year $t$ (that corresponds to the expected Sacramento Index in year $t$ conditional on a Sacramento Index in $t-1$ greater than or equal to 10) and the expected Sacramento Index in year $t$ conditional on the actual value of the Sacramento Index in year $t-1$.

$$
\text { Deductible }=\left(E\left(S I_{t}\right) \mid S I_{t-1} \geq 10\right)-\left(E\left(S I_{t}\right) \mid S I_{t-1}\right)
$$

The conditional deductible (as a percentage of the upper threshold $U$ ) varies as shown in equation 5.6 and the actuarially fair premium rate is constant at $7.76 \%$.

$$
\text { Deductible }(\%)=\left\{\begin{array}{cl}
-3.85 \times S I_{t-1}+38.46 & \text { if } S I_{t-1}<10 \\
0 & \text { if } S I_{t-1} \geq 10
\end{array} \quad \text { Adj } R^{2}=1\right.
$$




\subsubsection{Index insurance performance for Westlands Water District landowners and farmers}

The performance of the index insurance is tested by assuming that it is purchased by landowners or farmers who obtain irrigation water through the Westlands Water District (WWD). ${ }^{13}$ WWD is located in the San Joaquin Valley, in western parts of both Fresno and Kings Counties and is part of the San Luis Unit of the CVP. Much of the water supplied by the WWD is used for irrigation. There are likely other loss scenarios due to reduced water allocations that could be considered if sufficient data were available to estimate loss functions (e.g., switching from crops with higher expected returns but that require more water to those with lower expected returns but that require less water).

The effectiveness of the index insurance in reducing income variability is tested using loss functions assuming the current water management regulatory regime. The effectiveness of the index insurance can be analyzed by comparing the standard deviation of net loss outcomes with and without the insurance contract (Collier, Skees and Barnett 2009; Kellner and Musshoff 2011). In addition to the actuarially fair premium rate, premium loads of $10 \%, 20 \%$, and $30 \%$ are considered.

Losses experienced due to water shortages are analyzed for both landowners and farmers. The loss function for landowners assumes that reduced water allocations cause land to be left fallow. The loss function for farmers assumes that a crop is planted but, due to a reduced surface water allocation, significantly higher costs are incurred to pump groundwater for irrigation.

Since data for individual landowners or farmers is not available, the analysis is conducted for all irrigated acreage in the WWD. For both the landowner and farmer analysis, the tick size is determined by minimizing the standard deviation of the net loss function, calculated by deducting from any indemnities received, the actuarially-fair premium and the estimated losses incurred from fallowed land or from pumping groundwater. Insufficient data are available to test the insurance performance out of sample; consequently the hedging effectiveness of the index insurance design should be considered a best-case outcome.

Fallowed land is assumed to have no rental value for that year. Land acreage reports are available from 2000 to 2013 (Westlands Water District 2015). A negative correlation (-0.67) exists between the Sacramento Index and fallow land in the WWD for the period 2000-2013, confirming that fallow land increases in drought years. The loss in rental income on fallow land is measured considering the average annual cash rent per irrigated acre in California, obtained

${ }^{13}$ Drought conditions may also cause losses for a water supplier such as Westlands Water District (see Zeff and Charaklis 2013) but due to a lack of loss data for the water supplier, that scenario is not analyzed here. 
from the USDA (2015). These data exhibit a positive trend for the available period 1994-2008. In consequence, the data series was detrended to the 2008 level for this analysis. Due to a lack of data after 2008, average annual cash rent per irrigated acre was considered to be constant from 2008 to 2013. Table 5.4 shows the hedging effectiveness of the proposed index insurance using a loss function based on annual cash rent losses for the period 2000-2013.

Table 5.4. Hedging effectiveness of the index insurance schemes (Upper threshold $U=7.8$ ) proposed in Westlands Water District using a loss function based on annual cash rent losses (in million \$)

\begin{tabular}{|c|c|c|c|c|c|c|c|c|c|c|c|c|c|}
\hline & \multirow{3}{*}{$\begin{array}{l}\text { Without } \\
\text { insurance }\end{array}$} & \multicolumn{12}{|c|}{ With insurance } \\
\hline & & \multicolumn{4}{|c|}{$\begin{array}{l}\text { (1)Early bird contract. } \\
\text { Premium load: }\end{array}$} & \multicolumn{4}{|c|}{$\begin{array}{l}\text { (2) Variable premium. } \\
\text { Premium load: }\end{array}$} & \multicolumn{4}{|c|}{$\begin{array}{l}\text { (3)Variable deductible. } \\
\text { Premium load: }\end{array}$} \\
\hline & & $0 \%$ & $10 \%$ & $20 \%$ & $30 \%$ & $0 \%$ & $10 \%$ & $20 \%$ & $30 \%$ & $0 \%$ & $10 \%$ & $20 \%$ & $30 \%$ \\
\hline Tick & - & \multicolumn{4}{|c|}{7.9} & \multicolumn{4}{|c|}{6.2} & \multicolumn{4}{|c|}{6.8} \\
\hline $\begin{array}{l}\text { Std } \\
\text { dev }\end{array}$ & 10.93 & 7.79 & 7.79 & 7.79 & 7.79 & 9.26 & 9.4 & 9.54 & 9.68 & 10.18 & 10.18 & 10.18 & 10.18 \\
\hline $\begin{array}{c}\text { Max } \\
\text { losses }\end{array}$ & 56.25 & 48.22 & 49.02 & 49.81 & 50.61 & 52.68 & 53.58 & 54.48 & 55.37 & 55.26 & 55.66 & 56.05 & 56.45 \\
\hline
\end{tabular}

Compared to the no insurance scenario, all the insurance designs have a lower standard deviation of net losses. Furthermore, the maximum net loss is smaller for all of the insurance scenarios except for the variable deductible design with a $30 \%$ premium load. By comparing the different insurance designs, the early bird design is most effective in reducing cash rent variability, while the variable deductible design is the least effective.
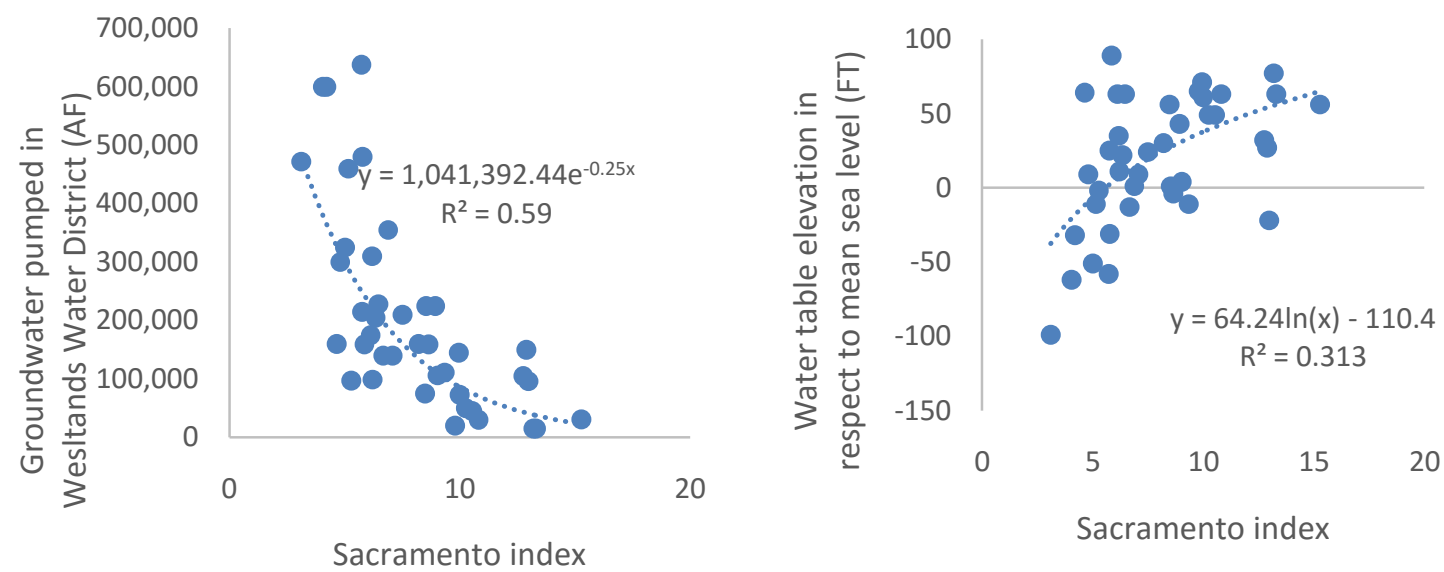

Figure 5.4. Relationship between Sacramento Index and (left) groundwater pumped in acre-feet (AF) or (right) water table elevation in feet (FT), Westlands Water District, 1974-2013 
The performance of the index insurance can also be tested using a loss function based on costs incurred for pumping groundwater. ${ }^{14}$ When needed, farmers in the WWD pump groundwater to replace shortfalls in anticipated CVP surface water deliveries. Data on the depth of the groundwater table and the amount of groundwater pumped in the WWD are available for the years 1974-2013 (Westlands Water District 2014). These data are used to estimate a loss function. Groundwater pumping costs are dependent on the amount of water pumped and the vertical height lifted. Figure 5.4 (left) presents the relationship between the Sacramento Index and groundwater pumping in the WWD. The higher the Sacramento Index (the higher the availability of surface water), the less groundwater is pumped. In Figure 5.4 (right), the relationship between the Sacramento Index and water table depth with respect to the sea level is shown. The higher the Sacramento Index, the higher is the water table (less energy is then needed to pump groundwater).

To estimate the costs of pumping groundwater, an energy intensity coefficient is used that estimates the kilowatt-hours $(\mathrm{KwH})$ needed to pump one acre-foot of groundwater depending on the vertical height lifted (Fraenkel 1986). The energy intensity coefficient $\left(\mathrm{e}_{\mathrm{GW}}\right)$ for selfsupplied, untreated groundwater used by the agricultural and industrial sectors is shown in equation 5.7. It depends on a lift parameter (l), hydraulic head (h), and pump efficiency $(\varepsilon)$

$$
e_{G W}=\frac{l * h}{\varepsilon}
$$

where $l$ is equal to1.027 KwH per 1 acre-foot of water per foot of depth, which is the theoretical energy required to lift a volume of water vertically from a well, assuming no friction and perfect pump efficiency, $\varepsilon$ is established at $50 \%$, considered an average pump efficiency in developed economies, and $h$ is the water table depth in feet. Westlands Water District average elevation is equal to 295 feet. The price of energy is assumed to be $\$ 0.248 / \mathrm{KwH}$ (Pacific Gas \& Electric Company 2014).

Based on these calculations, for the period 1974-2013 pumping costs for farmers in Westlands Water District averaged \$31.4 million per year, and varied between \$1.7 and \$114.7 million, with a standard deviation of $\$ 30.5$ million. Pumping costs averaged $\$ 140.40$ per acre-foot and varied between $\$ 104.90$ and $\$ 200.60$ per acre-foot, with a standard deviation equal to $\$ 22.10$ per acre-foot.

\footnotetext{
${ }^{14}$ The analysis presented here is based on the current situation with farmers generally having unrestricted rights to pump groundwater. In the future, as groundwater pumping restrictions authorized by recent state legislation take hold, farmers may wish to purchase the proposed index insurance to protect themselves against losses caused by seasonal pumping restrictions related to the value of the Sacramento Index.
} 
Table 5.5 shows the hedging effectiveness of the proposed index insurance using a loss function based on groundwater pumping costs for the period 1974-2013. As with the previous loss function, each of the insurance designs reduces the standard deviation of net losses, even with a $30 \%$ premium load. For this loss function, each of the insurance designs also reduces the maximum net loss. Again, the early bird contract is the most effective in reducing the variability of pumping costs.

Table 5.5. Hedging effectiveness of the index insurance schemes (Upper threshold $U=7.8$ ) proposed in Westlands Water District using a loss function based on groundwater pumping costs (in million \$)

\begin{tabular}{|c|c|c|c|c|c|c|c|c|c|c|c|c|c|}
\hline & \multirow{3}{*}{$\begin{array}{l}\text { Without } \\
\text { insurance }\end{array}$} & \multicolumn{12}{|c|}{ With insurance } \\
\hline & & \multicolumn{4}{|c|}{$\begin{array}{l}\text { (1)Early bird contract. } \\
\text { Premium load: }\end{array}$} & \multicolumn{4}{|c|}{$\begin{array}{l}\text { (2) Variable premium. } \\
\text { Premium load: }\end{array}$} & \multicolumn{4}{|c|}{$\begin{array}{l}\text { (3) Variable deductible. } \\
\text { Premium load: }\end{array}$} \\
\hline & & $0 \%$ & $10 \%$ & $20 \%$ & $30 \%$ & $0 \%$ & $10 \%$ & $20 \%$ & $30 \%$ & $0 \%$ & $10 \%$ & $20 \%$ & $30 \%$ \\
\hline Tick & - & \multicolumn{4}{|c|}{16.8} & \multicolumn{4}{|c|}{15.2} & \multicolumn{4}{|c|}{20.6} \\
\hline $\begin{array}{l}\text { Std } \\
\text { dev }\end{array}$ & 30.5 & 20.7 & 20.7 & 20.7 & 20.7 & 23.6 & 23.9 & 24.3 & 24.6 & 26.1 & 26.1 & 26.1 & 26.1 \\
\hline $\begin{array}{l}\text { Max } \\
\text { costs }\end{array}$ & 114.7 & 96.8 & 98.4 & 100.1 & 101.8 & 100.1 & 101.8 & 103.5 & 105.1 & 110.9 & 112.1 & 113.4 & 114.6 \\
\hline
\end{tabular}

It is important to recall that the insurance payment is in no way dependent on how the landowner or grower decides to react to a reduced water allocation. For this reason, the proposed index insurance product does not affect marginal conditions for input (land or water) demands. The insurance payout is completely unrelated to whether or not the landowner actually fallows acreage or whether or not the farmer actually pumps groundwater. The landowner is not required to plant to receive the insurance indemnity nor is the farmer required to pump groundwater. For this reason, the insurance product should have no detrimental environmental impacts. This is in contrast to traditional multiple-peril crop insurance which is tied directly to a farmer's production decisions and thus may affect marginal conditions for input (land or water) demands.

\subsection{Conclusion}

The California Central Valley is significantly exposed to water scarcity. An index insurance product adapted to the CVP is proposed as a means to provide landowners and farmers with protection against economic losses due to occasional reductions in surface water allocations. 
The index insurance proposed is based on the Sacramento Index, one of the indicators used as a trigger in water management regulations. The Sacramento Index signals shortages in CVP water deliveries including the effects of water diverted for environmental reasons. The implementation of the index insurance is straightforward, and its operating and administrative costs would be relatively small.

Due to changes in water regulations over time, the analysis could not be conducted using time series data on historical CVP water deliveries. Instead, a hydrologic model was used that simulates historical CVP water deliveries under an assumed regulatory regime. Reduced surface water deliveries were translated into monetary losses using two possible loss functions: one based on foregone rental revenue for landowners from land fallowed, and one based on increased costs to farmers from groundwater pumping. Three different index insurance designs were considered along with four different premium rate structures. Premium rates are assumed to be actuarially fair, and loaded by $10 \%$, loaded by $20 \%$, or loaded by $30 \%$.

Our results show that any of the insurance designs proposed does not completely offset losses arising from a reduction in surface water allocations. Index insurance would, however, reduce the losses, even when the insurance contains a 30\% premium load. This study demonstrates the potential for using index insurance to decrease the variability of economic losses caused by shortages in CVP water allocations. The analysis with premium rate loads suggests a market opportunity for insurance suppliers. Further research could extend this analysis to other irrigation districts and consider alternative index insurance designs.

Future research efforts could also examine whether the proposed insurance could provide risk reduction benefits to water market participants. In drought years the value of surface water increases. Thus, while holders of surface water rights may get reduced allocations, the value of the surface water they receive on a per unit basis will be higher - which creates a sort of natural hedge for those who sell in water markets. Due to impacts on local economies or environmental conditions, the ability of water rights holders to export water out of a local area is sometimes limited by local, state, or federal authorities (Chaudry et al. 2015). Such restrictions undermine the natural hedge and expose water sellers to greater revenue risk. The proposed index insurance could possibly be used by holders of water rights to compensate for the fact that water transfer restrictions have undermined the natural hedge in the value of annual water allocations. 


\section{CONCLUSIONS}

This thesis focuses on Hydrological Drought Index Insurance (HDII) as a mitigation tool against water supply risks in irrigated agriculture. Water supply risks are on the rise for different reasons: climate change, increasing demands, environmental concerns, and new water legislation leading in some cases to water supply restrictions. In developed countries, adaptation tools that reduce the risk, such as water infrastructure, water irrigation management, water saving methods or new crop varieties, are not sufficient enough to cope with water supply risks and irrigators still face important economic losses when water deliveries are strongly reduced. Mitigation tools that reduce the vulnerability become then necessary.

Water markets, crop insurance, and weather derivatives are the most noteworthy mitigation tools on which the farmer can count. Water markets are emerging in several countries, but water transactions remain still marginal. On the other hand, crop insurance strategy is mostly unavailable. The only insurance tool currently implemented to cover water shortages risk in irrigated agriculture consists of a MPCI in the United States, but it operates under very restrictive conditions. Although not implemented, some researches propose traditional insurance schemes, and others propose index insurance schemes and weather derivatives.

The main objective of this thesis was to carry out a study of an HDII as an insurance tool to help irrigators manage the risk of hydrological drought. The advantage of transferring irrigation water supply risk using an index insurance product is that it neither affects the input (e.g. land, water) demand marginal conditions nor the crop mix decisions. The insurance payment is in no way conditioned on how the landowner or grower decides to react to a reduced water allocation. For this reason, the insurance product should have no detrimental environmental impacts. This stands in contrast to products such as farm-level multiple-peril crop insurance which clearly could affect these marginal conditions and crop mix decisions.

Although it is not explored in this thesis, index insurance can be complementary to water markets. For instance, the insuree has the possibility to sell water rights. This would not be possible in MPCI insurance, since this behavior would affect crop production and so, loss adjustment would be then biased.

Besides, as has been repeatedly reported in the literature, index insurance is less vulnerable to moral hazard and adverse selection, is less expensive to administer, and is easier to reinsure because contracts are more transparent than for traditional crop insurance (with on-field lossassessment). 
The main thesis' findings and contributions for designing an HDII address four key aspects:

- Drought Index selection and validation

- Unitary indemnity estimation

- Dealing with intertemporal adverse selection

- Suitability and efficiency

\subsection{Drought Index selection and validation}

The principal challenge in designing index insurance is to find an index that fulfills the quality standards of the insurance industry (e.g., objectivity, transparency), correlates well with the insured losses, and generates sufficient demand (Collier et al. 2009). Underlying indices generally must be carefully selected or designed for each index insurance product (Vedenov and Barnett 2004).

The underlying index (DI) used for the proposed HDII should be a measure used by water managers for the distribution of water among users (institutional DI), provided it meets the quality standards of the insurance provider (Chapter 4 and 5). However, if there is not such a DI, it can be found empirically as the one that best estimates water allotments (Chapter 3).

The validation of the DI is based on basis risk quantification. Basis risk is the main disadvantage of index insurance schemes and stands for the variability in the relationship between the value of losses as measured by the index and the value of losses actually experienced by the insuree. The Coefficient of Determination $\left(\mathrm{R}^{2}\right)$ linking DI and water allotments (Chapter 5) is a partial measure of basis risk, since $\mathrm{R}^{2}$ does not account for how the level of water deliveries translates into economic losses. Basis risk is quantified in this thesis by comparing insurance indemnities and economic losses estimated from actual water allotments (Chapter 3 and 4). Due to basis risk, it is possible for the insuree to suffer a loss and yet not receive an indemnity (basis loss). Likewise, it is possible for the insuree to receive an indemnity when no loss has been realized (basis gain). Basis risk disaggregation in basis loss and basis gain (Chapter 3, and 4) helps to analyze whether the insurance scheme is adversely affecting policyholders or providers, leading to discontent among them. A high basis loss would dissuade farmers from buying the insurance. A high basis gain would make insurers to reconsider the viability of the index insurance scheme.

In addition, basis risk sources can be differentiated. This thesis has analyzed basis risk coming from the selected DI (Chapter 3) or coming from the use of an institutional DI (that is called 
institutional risk in this thesis, see Chapter 4); and basis risk coming from the use of an auxiliary index to avoid DI manipulation (Chapter 3, and 4).

The trade-off between basis risk and risk of index manipulation provide valuable information for agricultural policy design. By principle, DI in which the index insurance is based should not be subject to manipulation. However, sometimes this is unavoidable, as is the case for reservoir water stocks, which are usually a DI to be considered. Water stocks are even considered in institutional rules (Chapter 4) given the high correlation between this measure and water availability (Chapter 3). When reservoir water stocks might be subject to manipulation, the use of auxiliary indices (e.g. streamflows, meteorological drought indices) should be considered. However, as discussed in Chapter 3, auxiliary indices might not reflect some impediments that prevent water from being delivered to irrigators, such as a breakdown in the reservoir, or a pollution problem. Under these circumstances, irrigators would not receive an indemnity, but would suffer economic losses. Besides these exceptional occurrences, the correlation of the auxiliary index with the water allocation is always lower than that of the reservoir stocks. Using an Auxiliary Index causes an increase in total basis risk ${ }^{15}$ between $0.02 \%$ (NFD scheme in Chapter 3), and $1.3 \%$ (in Chapter 4).

Institutional (basis) risk comes from the institutional uncertainty in applying the established rules. In Chapter 4 institutional basis risk is equal to $1.2 \%$ (Basis Loss $=2.2 \%$, and Basis Gain=3.4\%). In order to implement this type of index insurance schemes, institutional rules or water distribution rules may be reliable and should remain constant over the guarantee period of the contract. Nevertheless, excessively rigid institutional rules might not be advisable to manage droughts. Droughts are difficult to characterize by means of drought indicators. Each drought should be addressed in a different way as there might be many other factors affecting the drought conditions (e.g., social, environmental, economic, etc.). In consequence, flexibility on the application of water distribution rules might seem desirable. This flexibility is transformed into institutional risk of the index insurance and we would benefit from further study of this trade-off.

This thesis highlights the fact that in some cases (e.g. recent or upcoming change in water management legislation or in water infrastructure) premium rate estimation cannot rely on historic DI. In such cases, premium rating should rely on water simulation models, since there would not be sufficient (or any at all) historic data on DI and water allotments for the new situation. In Chapter 5, a hydrologic model is used for simulating what would have happened in the past if the current regulatory regime had been in place.

\footnotetext{
${ }^{15}$ Total basis Risk (\%) = |Basis Gain (\%) - Basis Loss (\%)|
} 
This thesis contributes to the literature with a thorough analysis of basis risk, identifying several sources that enlighten important aspects of index insurance design. Conclusions contributing to address the challenge "Drought Index selection and validation" are summarized in the following points:

$\checkmark$ The trade-off between basis risk and risk of index manipulation provides valuable information for agricultural policy design.

$\checkmark$ Institutional (basis) risk originates from the institutional uncertainty in applying the established rules. Institutional rules or water distribution rules may be reliable and should remain constant over the guarantee period of the contract.

$\checkmark$ In case of a recent or upcoming change in water management legislation or in water infrastructure, premium rating should rely on water simulation models because historical data would not provide a measure of actual supply risks.

\subsection{Unitary indemnity estimation}

HDII designed in this thesis indemnifies the policyholder in two different ways: per $\mathrm{m}^{3}$ of water deficit suffered in the farm (as estimated from DI) in respect to the water allotment guaranteed (Chapter 3, and 4); and per DI points measured below the guaranteed threshold (i.e. tick of the contract) (Chapter 5).

In the first case, HDII requires establishing a model that converts DI into water allotment or water deficit in the farm. This model is part of the insurance policy, and requires that water distribution rules remain constant along the insurance policy validity period. Unitary indemnity per $\mathrm{m}^{3}$ of water deficit suffered in the farm, as estimated from the model, is based on the added value of water of the region and it is linked to crop production. It permits estimating more accurately the loss suffered by the farmer. As described in Chapter 3, the unitary indemnity varies depending on the water allocated to irrigation, since the marginal value of water increases with its scarcity. This thesis contributes to the literature in linking water value methods to index insurance schemes.

When the unitary indemnity is linked to DI points, it corresponds to the tick of the contract. The implementation of this HDII scheme is then similar to weather derivatives, since the unitary indemnity estimation is not attached to cropland. It could potentially be sold to other stakeholders such as water suppliers. Tick size is determined in Chapter 5 in such a way that it minimizes the standard deviation of the loss function estimated for the Irrigation District analyzed. 
Conclusions contributing to address the challenge "Unitary indemnity estimation" are summarized in the following points:

$\checkmark \quad$ A unitary indemnity per $\mathrm{m}^{3}$ of water deficit based on the added value of water of the region allows linking the insurance contract to cropland.

$\checkmark$ A unitary indemnity that varies depending on the water allocated to irrigation shows how the marginal value of water increases with its scarcity.

$\checkmark$ A unitary indemnity per index points (tick of the contract) facilitates the use of an HDII by other stakeholders affected economically by water shortages, such as water suppliers.

\subsection{Dealing with intertemporal adverse selection}

Risk of intertemporal adverse selection comes from the fact that pre-season weather information can influence crop insurance decisions (Carriquiry and Osgood 2012). Water availability might be forecasted due to the inertial behavior of the water supply system. In inertial water supply systems, reservoir capacity is large relative to annual inflows and water demands. One way to measure the inertia is to evaluate the correlation between reservoir stocks at the beginning of the crop season (when insurance policy are usually purchased) and the reservoir stocks at the beginning of the irrigation season.

Although the risk of intertemporal adverse selection has been mentioned in the literature in the framework of HDII (Brown and Carriquiry 2007), the issue has not been directly addressed. Chapters 4 and 5 contribute to the literature by proposing insurance schemes dealing effectively with intertemporal adverse selection. Several alternative designs are proposed: early bird design (Chapter 4, and 5) variable premium design (Chapter 4, and 5), and variable deductible design (Chapter 5).

Early bird design at a constant premium rate could be sold before any water availability forecast can be made. In the case studies analyzed, constant premium ranges between $12.8 \%$ and $14.5 \%$ over the liability for $100 \%$ coverage. It appears as the most effective in reducing risk exposure and the most suitable for high-inertial water supply systems.

Premium rates for the early bird design are high compared to those calculated for the Riegos de Bardenas case study (non-inertial system), which vary between $0.4 \%$ and $1.8 \%$ over the liability. This shows that inertial-systems, which are pose greater difficulties for developing drought insurance, are also those more exposed to drought risk. 
To overcome the fact that policyholders may not be willing to pay the rate in advance for the early bird design, one possibility would be to link the early-bird contract purchase to the CAP subsidies or to an option contract with the insurance company (Chapter 4). Option contract rating should need further research. The potential demand for early-bird contracts needs as well further research.

Variable premium and variable deductible designs are sold once water availability forecasts could be structured based on pre-season information. Pre-season information is used to adjust the premium (in variable premium design) or the deductible (in variable deductible design) to the actual risk undertaken. The variable premium design presents too high premium rates when water shortages are forecasted. Multi-year contracts can be sold in order to average-out the premium rates between the different pre-season scenarios. In Chapter 4, premium rate when the pre-season information indicates a drought status of emergency is equal to $41 \%$ (over the liability). And with a 3-year contract, it decreases to $26 \%$.

The purchaser of an insurance product with the variable deductible design (and constant premium rate) would be concerned about protecting only against shortfalls in DI that could not have been anticipated given the pre-season information. A budget-constrained purchaser might be more interested in the variable deductible design.

This thesis contributes to the literature in directly addressing intertemporal adverse selection in hydrological drought index insurance for irrigated agriculture. Conclusions contributing to address the challenge "dealing with intertemporal adverse selection" are summarized in the following points:

$\checkmark$ Intertemporal adverse selection is a key challenge for Hydrological Drought Index Insurance in water supply systems presenting inertial behavior.

$\checkmark$ Inertial-systems, which are pose greater difficulties for developing drought insurance, are also those more exposed to drought risk.

$\checkmark$ The use of pre-season information or early-bird contracts avoids intertemporal adverse selection.

$\checkmark$ Early-bird design at a constant premium rate could be sold before any water availability forecast can be made.

$\checkmark$ Early-bird design is most effective in reducing risk exposure.

$\checkmark$ Early-bird contracts are preferred in water supply systems with a strong inertial behavior.

$\checkmark$ Pre-season information is used to adjust the premium rate in variable premium design to the actual risk undertaken. 
$\checkmark$ Pre-season information is used to adjust the deductible in variable deductible design (sold at a constant premium rate) to the actual risk undertaken.

$\checkmark$ Multi-year contracts average-out premium rates between the different pre-season scenarios in variable premium design.

$\checkmark$ Variable deductible design protects only against shortfalls in DI that could not have been anticipated given the pre-season information.

$\checkmark$ A budget-constrained purchaser might be more interested in the variable deductible design.

\subsection{Suitability and hedging effectiveness analysis}

Suitability of the HDII for the Spanish framework (crop insurance system, irrigated agriculture, and water management) was discussed by the use of an Expert Panel. The expert panel determined that the best option to ensure irrigated crops in Spain is a Hydrological Drought Index Insurance (HDII) contracted by the Irrigation District.

The hedging effectiveness of HDII at different premium rate structures (actuarially fair premium and different premium loads) is addressed in Chapter 3, and 5. Hedging effectiveness is analyzed comparing several loss scenarios with and without insurance. Loss functions analyzed in this thesis are: drops in gross margin caused by reduced water allocations (Chapter 3), the loss in rental income on fallow land (Chapter 5), and increase in costs incurred to pump groundwater for irrigation (Chapter 5).

Results suggest that HDII would be useful in providing economic stability to policyholders, and the margin to load the premium rate reveals a market opportunity to insurance suppliers. HDII considering a premium load of $40 \%$, reduces the standard deviation of gross margin in region analyzed in Chapter 3 in 18\% (NFD design) and in 8\% (FD design), and the minimum gross margin is incremented by $2 \%$. In the case study analyzed in Chapter 5 , early bird design considering a premium load of $30 \%$ reduces the standard deviation of loss functions analyzed in $29 \%$ (loss function considering rental income losses) and in 32\% (loss function considering groundwater pumping costs). Maximum losses and maximum costs are reduced in $10 \%$ and in $11 \%$ respectively.

Conclusions contributing to address the challenge "Suitability and hedging effectiveness analysis" are summarized in the following points:

$\checkmark$ The expert panel determined that the best option to ensure irrigated crops in Spain is a Hydrological Drought Index Insurance (HDII) contracted by the Irrigation District. 
$\checkmark$ Results from Chapter 3 and 5 suggest that HDII would be useful to provide economic stability to policyholders.

$\checkmark$ The margin to load the premium rate (as tested in Chapter 3 and 5) reveals a market opportunity to insurance suppliers.

\subsection{Limitations and further research}

In this thesis different key challenges in designing HDII are addressed and interesting results and conclusions arise. However, there are some limitations that could be addressed with appropriate and longer data series:

- Unitary indemnity estimation and hedging effectiveness analysis in Chapter 3 rely on provincial and regional data, and not on local data. This could be a source of inaccuracies in the results that could be addressed with appropriate and longer data series.

- Insufficient data are available to test the insurance performance out of sample; consequently the hedging effectiveness of the index insurance design should be considered a best-case outcome.

- In chapter 5, empirical analysis of the performance of the HDII is not complete in the sense that it does not include all potential buyers of the proposed insurance product, such as water suppliers, due to the lack of a loss function (that would translate reduced water deliveries into economic losses).

- In hedging effectiveness analysis, other loss scenarios due to reduced water allocations could also be considered with sufficient data to do so (e.g., switching from crops with higher expected returns but that require more water to those with lower expected returns but that require less water).

Further research efforts could examine:

- The potential demand of HDII (including designs dealing with intertemporal adverse selection). It would be of interest for insurance companies.

- The possibilities and difficulties for reinsuring HDII. It would be of interest for insurance companies.

- The link between the early-bird contract purchase and an option contract with the insurance company, to avoid the payment of the premium rate in advance by policyholders. 
- HDII and water markets interaction, such as the risk reduction benefits that HDII could provide to water market participants.

- How HDII could help manage water resources at basin scale, addressing drought cycles and management decisions under drought conditions.

- How could HDII help better manage key strategic resources, like groundwater resources. 



\section{REFERENCES}

AFSC (Agriculture Financial Services Corporation) (2015a) Moisture Deficiency Insurance. https://www.afsc.ca/doc.aspx?id=7859. Accessed 1 October 2015

AFSC (Agriculture Financial Services Corporation) (2015b) Satellite Yield Insurance. AFSC Web site. http://www.afsc.ca/doc.aspx?id=3360. Accessed 1 October 2015

Agricorp (2015) Production insurance program for forage rainfall. Cultivate risk reduction. Agricorp, Ontario.

Agroseguro (2015a) Condiciones del seguro de compensación por pérdida de pastos. Agroseguro Web site. http://agroseguro.es. Accessed 5 May 2015

Agroseguro (2015b) El sistema español de seguros agrarios en cifras 1980/2014. Agroseguro, Madrid

AIC (Agriculture Insurance Company of India Limited) (2015) Rainfall Insurance Scheme - Coffee and Varsha Bima (Rainfall Insurance). AIC Web site. http://www.aicofindia.com. Accessed 5 May 2015

Australian Bureau of Meteorology (2015) Deciles. Australian Government Bureau of Meteorology Website. http://www.bom.gov.au/climate/glossary/deciles.shtml. Accessed September 2015

Bao Minh (2015) Drought Risk for Coffee in Daklak. http://www.baominh.com.vn/vi-vn/chuyenmuc948-bao-hiem-nong-nghiep-tintuc-3302-bao-hiem-gian-doan-kinh-doanh-nong-nghiep-theo-chiso.aspx. Accessed September 2015

Bardenas (2012) Comunidad General Canal de Bardenas. Modernización de regadíos. Jornada Técnica de Modernización de Regadíos en 6 octubre 2012. http://www.coiaanpv.org. Accessed 10 January 2015

Bardenas V (2015) Memoria de la Comunidad nº V (2003-2014). Bardenas V Web site. http://www.comunidadv.com/. Accessed 10 February 2015

Barnett BJ (2004) Agricultural Index Insurance products: Strengths and limitations. In Agricultural Outlook Forum. pp. 1-19

Barnett BJ, Barrett CB, Skees JR (2008) Poverty Traps and Index-Based Risk Transfer Products. World Dev 36(10):1766-1785

Barnett BJ, Mahul O (2007) Weather index insurance for agriculture and rural areas in lower-income countries. Am J Agr Econ 89(5):1241-1247

Berbel J, Mesa-Jurado MA, Pistón JM (2011) Value of Irrigation Water in Guadalquivir Basin (Spain) by Residual Value Method. Water Resour Manag 25(6):1565-79

Bielza M, Conte C, Dittmann C, Gallego J, Stroblmair J (2008) Agricultural Insurance Schemes. Directorate General, JRC. European Commission

Brown C, Carriquiry M (2007) Managing hydroclimatological risk to water supply with option contracts and reservoir index insurance. Water Resour Res 43, W11423

Buchholz M, Musshoff O (2014) The role of weather derivatives and portfolio effects in agricultural water management. Agr Water Manage 146(February):34-44

Byun HR, Wilhite DA (1999) Objective Quantification of Drought Severity and Duration. J Climate 12(9):2747-2756

California Department of Water Resources (1994) The San Francisco bay-delta agreement. http://www.calwater.ca.gov/content/Documents/library/SFBayDeltaAgreement.pdf. Accessed June 2015

California Department of Water Resources (2007) California Central Valley Unimpaired Flow Data. http://www.waterboards.ca.gov/waterrights/water_issues/programs/bay_delta/bay_delta_plan/water _quality_control_planning/docs/sjrf_spprtinfo/dwr_2007a.pdf. Accessed January 2016 
California Department of Water Resources (2015a) California Data Exchange Center. http://cdec.water.ca.gov/cgi-progs/iodir/WSIHIST. Accessed June 2015

California Department of Water Resources (2015b) California State Water Project and the Central Valley Project. http://www.water.ca.gov/swp/cvp.cfm. Accessed June 2015

California Department of Water Resources, United States Bureau of Reclamation (2011) CalLite Central Valley Water Management Screening Model (Version 2.00). User's Guide

California Department of Water Resources, United States Bureau of Reclamation (2014) CalLite Central Valley Water Management Screening Model (Version 3.00) Reference Manual

California State Water Resources Control Board (1978) Water right decision 1485. http://www.waterrights.ca.gov/hearings/decisions/WRD1485.PDF. Accessed January 2016

California State Water Resources Control Board (2000) Water Right Decision 1641. http://www.waterboards.ca.gov/waterrights/board_decisions/adopted_orders/decisions/d1600_d164 9/wrd1641_1999dec29.pdf. Accessed January 2016

California State Water Resources Control Board (2006) Water Quality Control Plan for the San Francisco Bay / Sacramento-San Joaquin Delta Estuary.

Cao M, Wei J (2004) Weather derivatives valuation and market price of weather risk. J Futures Markets 24(11):1065-1089

Carriquiry M, Osgood DE (2012) Index Insurance, Probabilistic Climate Forecasts, and Production. J Risk Insur 79(1):287-300

Causapé J (2009) Aprovechamiento del agua en los regadíos de Bardenas. Inf técnica Económica Agrar 105(3):202-221

Changnon SA (2007) New risk assessment products for dealing with financial exposure to weather hazards. Nat Hazards 43:295-301

Chaudhry AM, Fairbanks DH, Caldwell A (2015) Determinants of Water Sales During Droughts: Evidence from Rice Farm-Level Data in California. In 2015 Agricultural and Applied Economics Association \& Western Agricultural Economics Association Joint Annual Meeting. July 26-28, San Francisco, California

CHE (Confederación Hidrográfica del Ebro) (2007) Plan especial de actuación en situaciones de alerta y eventual sequía en la cuenca hidrográfica del Ebro. Confederación Hidrográfica del Ebro, Saragossa

CHE (Confederación Hidrográfica del Ebro) (2013) Anejo VI Sistemas de explotación y balances. In: Propuesta de proyecto de plan hidrológico de la cuenca. Confederación Hidrográfica del Ebro, Saragossa

CHE (Confederación Hidrográfica del Ebro) (2014) La Confederación del Ebro inicia los trabajos de ejecución del cuerpo de presa para el recrecimiento del embalse de Yesa. http://www.chebro.es/contenido.visualizar.do?idContenido=41889. Accessed 22 February 2015

CHG (Confederación Hidrográfica del Guadalquivir) (2007) Plan especial de actuación en situaciones de alerta y eventual sequía en la cuenca hidrográfica del Guadalquivir. MAGRAMA, Seville

CHG (Confederación Hidrográfica del Guadalquivir) (2015) Sistema Automático de Información Hidrológica de la Cuenca del Guadalquivir. CHG Web site. http://www.chguadalquivir.es/saih/. Accessed 15 May 2015

CHJ (Confederación Hidrográfica del Júcar) (2007) Plan especial de alerta y eventual sequía en la confederación hidrográfica del Júcar. Confederación Hidrográfica del Júcar, Valencia

Choudhury A, Jones J, Okine A, Choudhary R (2015) Drought Triggered Index Insurance Using Cluster Analysis of Rainfall Affected by Climate Change. Illinois State University, Normal, Illinois

CME Group (2015) Weather products. CME Group Web site. http://www.cmegroup.com/trading/weather/. Accessed 15 April 2015

Coble KH, Barnett BJ (2008) Implications of Integrated Commodity Programs and Crop Insurance. Journal of Agricultural and Applied Economics 2(August):431-442 
Coble KH, Barnett BJ (2013) Why Do We Subsidize Crop Insurance? Am J Ag Econ 95(2):498-504

Collier B, Barnett BJ, Skees JR (2011) State of Knowledge Report - Data Requirements for the Design of Weather Index Insurance. GlobalAgRisk project report, Innovation in Catastrophic Weather Insurance to Improve the Livelihoods of Rural Households, The Bill and Melinda Gates Foundation, Seattle, WA

Collier B, Skees JR, Barnett BJ (2009) Weather Index Insurance and Climate Change: Opportunities and Challenges in Lower Income Countries. Geneva Pap R I-Iss P 34(3):401-24

Curiel P (2012) Régimen jurídico de las sequías: crítica a la regulación extraordinaria y urgente de un fenómeno natural y cíclico propio del clima. Revista de Administración Pública 187:199-240

Del Moral L (coord.) (1998) El sistema de abastecimiento de agua de Sevilla: Análisis de situación y alternativas al embalse del Melonares, Bakeaz. Nueva cultura del agua, Bilbao

Dooley DM (2015) The role of groundwater in California. In Botin/Rosenberg workshop on drought. January 29, 2015. Madrid

Easter W, Huang Q (eds) (2014) Water Markets for the 21st. Century: What Have We Learned?. Springer, New York

EC (European Commission) (2006) Commission Regulation (EC) No 1998/2006 of 15 December 2006 on the application of Articles 87 and 88 of the Treaty to de minimis aid. Official Journal of the European Union L 379: 5-10

EC (European Commission) (2007a) Green paper from the Commission to the Council, the European Parliament, the European Economic and Social Committee and the Committee of the Regions: Adapting to climate change in Europe - options for EU action.

EC (European Commission) (2007b) Water Scarcity and Droughts In-Depth Assessment. Second Interim report, June 2007

EC (European Commission) (2014) European Union Guidelines for State aid in the agriculture and forestry sector and in rural areas 2014 to 2020. Official Journal of the European Union C204:1-97

Elabed G, Bellemare MF, Carter MR, Guirkinger C (2013) Managing basis risk with multiscale index insurance. Agric Econ (United Kingdom) 44:419-431

ENESA (2012) La sequía, Un riesgo incluido en los seguros agrarios. Noticias Del Seguro Agrario $82: 3-4$

Estrela T, Vargas E (2012) Drought Management Plans in the European Union. The Case of Spain. Water Resour Manag 26(6):1537-1553

EU (European Union) (2013) Regulation (EU) No 1305/2013 of the European Parliament and of the Council of 17 December 2013 on support for rural development by the European Agricultural Fund for Rural Development (EAFRD) and repealing Council Regulation (EC) No 1698/2005. Official Journal of the European Union L347:487-548

Fraenkel PL (1986) Water lifting devices. FAO irrigation and drainage papers 43

Gibbs WJ, Maher JV (1967) Rainfall Deciles as Drought Indicators. Australian Bureau of Meteorology Bulletin 48

Giné X, Townsend R, Vickery J (2007) Statistical analysis of rainfall insurance payouts in Southern India. Am Journal Agr Econ 89(5):1248-1254

GlobalAgRisk (2009) Designing Agricultural Index Insurance in Developing Countries: A GlobalAgRisk Market Development Model Handbook for Policy and Decision Makers. GlobalAgRisk, Lexington, Kentucky

Griffin D, Anchukaitis KJ (2014) How unusual is the 2012 - 2014 California drought ? Geophys Res Lett 41(24):9017-9023

Hanak E, Lund J, Dinar A, Gray B, Howitt R (2011) Managing California's Water From Conflict to Reconciliation. San Francisco, California: Public Policy Institute of California

Hanak E, Stryjewski, E (2012) California’s Water Market, By the Numbers: Update 2012. Report, Public 
Policy Institute of California. http://www.ppic.org/content/pubs/report/R_1112EHR.pdf. Accessed January 2016

Hartell J, Ibarra H, Skees J, Syroka J (2006) Risk Management in Agriculture for Natural Hazards. ISMEA, December 2006

Hazell P, Anderson J, Balzer N, Hastruo Clemensen A, Hess U, Rispoli F (2010) Potential for Scale and Sustainability in Weather Index Insurance for Agriculture and Rural Livelihoods. International Fund for Agricultural Development and World Food Program, Rome

Heim RR (2002) A review of twentieth-century drought indices used in the United States. B Am Meteorol Soc (August):1149-1166

Hellmuth ME, Osgood DE, Hess U, Moorhead A, Bhojwani H (eds) (2009) Index insurance and climate risk: Prospects for development and disaster management. Climate and Society No. 2. International Research Institute for Climate and Society (IRI), Columbia University, New York, USA

Hess U, Syroka J (2005) Weather-based Insurance in Southern Africa The Case of Malawi. Agriculture and rural development discussion paper 43. The International Bank for Reconstruction and Development / The World Bank, Washington

Howitt R, Medellín-Azuara J, MacEwan D, Lund J, Sumner D (2014) Economic Analysis of the 2014 Drought for California Agriculture. Center for Watershed Sciences, University of California, Davis, California. 20p

Iglesias E, Garrido A, Gómez-Ramos A (2003) Evaluation of drought management in irrigated areas. Agr Econ 29(2):211-229

Iglesias E, Garrido A, Gómez-Ramos A (2007) Economic drought management index to evaluate water institutions' performance under uncertainty. Australian J Agr Resource Econ 51(1):17-38

INE (Instituto Nacional de Estadística) (2012) Censo agrario 2009. Instituto Nacional de Estadística, Madrid, Spain

INE (Instituto Nacional de Estadística) (2015) Encuesta sobre el uso del agua en el sector agrario, Serie 2000-2013. http://www.ine.es/dyngs/INEbase/es/operacion.htm?c=Estadistica_C\&cid=1254736176839\&menu $=$ resultados\&idp $=1254735976602$

IPCC (Intergovernmental Panel on Climate Change) (2012) Summary for Policymakers. In: Field CB, Barros V, Stocker TF, Qin D, Dokken DJ, Ebi KL, Mastrandrea MD, Mach KJ, Plattner GK, Allen SK, Tignor M, Midgley PM (eds) Managing the Risks of Extreme Events and Disasters to Advance Climate Change Adaptation. A Special Report of Working Groups I and II of the Intergovernmental Panel on Climate Change. Cambridge University Press, Cambridge, UK, and New York, NY, USA, pp. 1-19

IPCC (Intergovernmental Panel on Climate Change) (2014) Climate Change 2014: Synthesis Report. Contribution of Working Groups I, II and III to the Fifth Assessment Report of the Intergovernmental Panel on Climate Change. IPCC, Geneva, Switzerland

IRI (Instituto Internacional de Investigación para el Clima y la Sociedad) (2010) Seguros en base a índices climáticos y riesgo climático : Perspectivas para el desarrollo y la gestión de desastres. Clima y sociedad 2

IRMI (International risk Management Institute) (2014) Glossary of Insurance \& Risk Management Terms. http://www.irmi.com/online/insurance-glossary/default.aspx. Accessed 14 July 2014

Islam N, Arora S, Chung F, Reyes E, Field R, Munévar A, Sumer D, Parker N, Chen ZQR (2011) CalLite: California Central Valley Water Management Screening Model. J Water Res Pl-ASCE 137(February):123-133

Johansson RC, Tsur Y, Roe T, Doukkali R, Dinar A (2002) Pricing irrigation water: a review of theory and practice. Water Policy 4:173-199

Johnson R, Cody BA (2015) California Agricultural Production and Irrigated Water Use. Congresional Research Service 
Kapphan I, Calanca P, Holzkaemper A (2012) Climate Change, Weather Insurance Design and Hedging Effectiveness. Geneva Pap Risk Insur Issues Pract 37(2):286-317

Kellner U, Musshoff O (2011) Precipitation or water capacity indices? An analysis of the benefits of alternative underlyings for index insurance. Agric Syst 104(8):645-653

Ker AP, McGowan P (2015) Weather-Based Adverse Selection and the US Crop Insurance Program: The Private Insurance Company Perspective. J Agr Resour Econ 25(2):386-410

Keyantash J (2002) The quantification of drought: An evaluation of drought indices. B Am Meteorol Soc (August): 1167-1180

La Positiva (2015) Seguro agrícola catastrófico. https:// https://www.lapositiva.com.pe/principal/seguros/seguro-agricola-catastrofico/1023/c-1023. Accessed June 2015

Leblois A, Quirion P (2010) Agricultural Insurances Based on Meteorological Indices: Realizations, Methods and Research Agenda. Sustainable development Series, Fondazione Eni Enrico Mattei

Leiva A, Skees J (2008) Using Irrigation Insurance to Improve Water Usage of the Rio Mayo Irrigation System in Northwestern Mexico. World Dev 36(12):2663-2678

Lorite IJ, García-Vila M, Carmona MA, Santos C, Soriano MA (2012) Assessment of the Irrigation Advisory Services' Recommendations and Farmers' Irrigation Management: A Case Study in Southern Spain. Water Resour Manag 26(8):2397-2419

Luo H, Skees JR, Marchant MA (1994) Weather information and the potential for intertemporal adverse selection in crop insurance. Rev Agr Econ 16(3):441-451

Maestro T, Bielza M, Garrido A (2016) Dealing with intertemporal adverse selection in hydrological drought index insurance. Working paper, Technical University of Madrid

Mafoua E, Turvey C (2003) Weather Insurance to Protect Specialty Crops Against Costs of Irrigation in Drought Years. In American Agricultural Economics Association Annual Meeting. Montreal, Canada. http://ageconsearch.umn.edu/bitstream/21922/1/sp03ma13.pdf.

Magallanes (2015) Seguro contra riesgos climáticos. https:// http://www.magallanes.cl/MagallanesWebNeo/index.aspx?channel=8102. Accessed June 2015

MAGRAMA (Ministerio de Agricultura, Alimentación y Medio Ambiente) (2008) La gestión de la sequía de los años 2004 a 2007. MAGRAMA, Madrid

MAGRAMA (Ministerio de Agricultura, Alimentación y Medio Ambiente) (2012) Análisis de la economía de los sistemas de producción. Resultados técnico-económicos de explotaciones agrícolas de Aragón en 2007-2011. Ministerio de Agricultura Alimentación y Medio ambiente, Madrid, Spain

MAGRAMA (Ministerio de Agricultura, Alimentación y Medio Ambiente) (2013a) Resultados técnicoeconómicos de Cultivos Herbáceos 2011. Subdirección General de Análisis, Prospectiva y Coordinación, Subsecretaría Ministerio de Agricultura Alimentación y Medio ambiente, Madrid, Spain

MAGRAMA (Ministerio de Agricultura, Alimentación y Medio Ambiente) (2013b) Resultados técnicoeconómicos de Cultivos Leñosos 2011. Subdirección General de Análisis, Prospectiva y Coordinación, Subsecretaría Ministerio de Agricultura Alimentación y Medio ambiente, Madrid, Spain

MAGRAMA (Ministerio de Agricultura, Alimentación y Medio Ambiente) (2013c) El Ministerio de Agricultura, Alimentación y Medio Ambiente suscribe un convenio para la modernización de 11.848 hectáreas de regadío en Sevilla. MAGRAMA Web site. http://www.magrama.gob.es/es/prensa/13.07.29\%20Convenio\%20SEIASA\%20regad\%C3\%ADos \%20Sevilla_tcm7-290966_noticia.pdf. Accessed 29 July 2013

MAGRAMA (Ministerio de Agricultura, Alimentación y Medio Ambiente) (2014a) Anuario de estadística. Ministerio de Agricultura, Alimentación y Medio Ambiente. http://www.magrama.gob.es. Accessed 2 June 2014 
MAGRAMA (Ministerio de Agricultura, Alimentación y Medio Ambiente) (2014b) ESYRCE: encuesta sobre superficies y rendimientos de cultivos. Ministerio de Agricultura, Alimentación y Medio Ambiente, Madrid, Spain

MAGRAMA (Ministerio de Agricultura, Alimentación y Medio Ambiente) (2015) Anuario de aforos. MAGRAMA Web site. http://sig.magrama.es/aforos/. Accessed 15 May 2015

Mahul O (1999) Optimum Area Yield Crop Insurance. Am J Agr Econ 81(1):75-82

Mahul O, Stutley CJ (2010) Government Support to Agricultural Insurance: Challenges and Options for Developing Countries. World Bank Publications

Mai B, Hung N (2013) Sale of drought insurance for coffee suspended. Mars 25, 2013 from The Saigon Times Web site at http://english.thesaigontimes.vn

Martin SW, Barnett BJ, Coble KH (2001) Developing and Pricing Precipitation Insurance. J Agr Resour Econ 26(1):261-274

Massey FJ (1951) The Kolmogorov-Smirnov test for goodness of fit. J Am Stat Assoc 46(253):68-78

McKee T, Doesken N (1993) The relationship of drought frequency and duration to time scales. In 8th Conference on Applied Climatology.

http://ccc.atmos.colostate.edu/relationshipofdroughtfrequency.pdf

Milly PCD, Dunne KA, Vecchia AV (2005) Global pattern of trends in streamflow and water availability in a changing climate. Nature 438(November):347-350

Miranda MJ (1991) Area-yield crop insurance reconsidered. Am J Agr Econ 73(2):233-242

Miranda MJ, Farrin K (2012) Index insurance for developing countries. Applied Economic Perspectives and Policy 34(3):391-427

Mukherjee M, Schwabe K (2015) Irrigated Agricultural Adaptation to Water and Climate Variability: The Economic Value of a Water Portfolio. Am J Agr Econ 97(3): 809-832

National Marine Fisheries Service (2009) Biological opinion and conference opinion on the long-term operations of the Central Valley Project and State Water Project. https://nrm.dfg.ca.gov/FileHandler.ashx?DocumentID=21473. Accessed January 2015

NDMC (National Drought Mitigation Center) (2015) Climate Division Standardized Precipitation Index (SPI). NDMC Website. http://drought.unl.edu/AboutUs.aspx. Accessed September 2015

Niemeyer S (2008) New drought indices. Water Management Options Méditerranéennes Série A (80):267-274

North MT, Turvey C, Osgood D (2013) Quantifying Spatial Basis Risk for Weather Index Insurance. Journal of Risk Finance 14(1):20-34

OECD (2011) Managing Risk in Agriculture. Policy Assessment and Design. Organisation for economic co-operation and development. OECD Publishing

Oficina del Riesgo Agropecuario (2010) Gestión de Riesgos y la Experiencia en el aseguramiento en la Argentina. In Fourth Conference on Agricultural Risk and Insurance. Buenos Aires, Argentina

Osgood DE, Suarez P, Hansen J, Carriquiry M, Mishra A (2008) Integrating Seasonal Forecasts and Insurance for Adaptation among Subsistence Farmers: The Case of Malawi. Policy Research Working Paper 4651. The World Bank

Pacific Gas \& Electric Company (2014) Large agricultural average total rate for May-Sep 2014. http://www.pge.com/nots/rates/tariffs/rateinfo.shtml. Accessed June 2015

Palisade Corporation (2015) Guide to Using @ Risk. http://www.palisade.com/downloads/documentation/7/EN/RISK7_EN.pdf. Accessed January 2016

Palmer WC (1965) Meteorologic Drought. US Department of Commerce, Weather Bureau, Research Paper No. 45

Palmer WC (1968) The abnormally dry weather of 1961-1966 in the northeastern United States. In NY University (Ed.) Drought in the North eastern United States, pp. 32-56 
Pérez Blanco CD, Gómez Gómez CM (2013) Designing optimum insurance schemes to reduce water overexploitation during drought events: a case study of La Campiña, Guadalquivir River Basin, Spain. J Environ Econ Policy 2(1):1-15

Pérez Blanco CD, Gómez Gómez CM, Del Villar García A (2011) El riesgo de disponibilidad de agua en la agricultura: una aplicación a las cuencas del Guadalquivir y del Segura. Estudios de Economía Aplicada 29:333-358

Pérez y Pérez L, Barreiro-Hurlé J (2009) Assessing the socio-economic impacts of drought. Span J Agric Res 7(2):269-280

Peters AJ, Walter-Shea EA, Ji L, Viña A, Hayes M, Svoboda MD (2002) Drought monitoring with NDVI-based standardized vegetation index. Photogramm. Eng Rem S 68(1):71-75

Prudhomme C, Giuntoli I, Robinson EL, Clark DB, Arnell NW, Dankers R, et al. (2014) Hydrological droughts in the 21 st century, hotspots and uncertainties from a global multimodel ensemble experiment. Proceedings of the National Academy of Sciences of the United States of America 111(9):3262-3267

Quiroga S, Garrote L, Fernandez-Haddad Z, Iglesias A (2011) Valuing drought information for irrigation farmers: potential development of a hydrological risk insurance in Spain. Spanish J Agric Res 9(4):1059-1075

Rey D, Calatrava J, Garrido A (2015) Comparison of different water supply risk management tools for irrigators: option contracts and insurance. Environ Resource Econ. DOI 10.1007/s10640-015-99122

Rey D, Garrido A, Calatrava J (2014) The Water Markets in Spain: moving towards 21st century mechanisms and approaches with 20th century regulations. In: Easter W and Huang Q (eds.) Water Markets for the 21st. Century: What Have We Learned? Springer, pp 127-147

Ritter M, Musshoff O, Odening M (2012) Minimizing Geographical Basis Risk of Weather Derivatives Using A Multi-Site Rainfall Model. Comput Econ 44(1):67-86

RMA (Risk Management Agency) (2014) Rainfall and Vegetation Index - Pasture, Rangeland and Forage. http://www.rma.usda.gov/policies/pasturerangeforage/shares.pdf. Accessed January 2016

RMA (Risk Management Agency) (2015) 2015 Crop Policies and Pilots. http://www.rma.usda.gov/policies/2015policy.html. Accessed June 2015

RMA-Topeka (Risk Management Agency - Topeka) (2015) Risk Management Agency Update, conference presented at Water symposium, Arkansas Valley Farm. http://www.farmranchwater.org/2015/Presentations/RMA.pdf

Rodríguez Díaz JA, Weatherhead EK, Knox JW, Camacho E (2007) Climate change impacts on irrigation water requirements in the Guadalquivir river basin in Spain. Reg Environ Change 7(3):149-159

Rodríguez N, Sánchez T, López J (2008) Un análisis de la eficiencia socioeconómica del agua en el regadío andaluz. Revista Española de Estudios Agrosociales Y Pesqueros 217:183-208

Rouse JW, Haas RH, Schell JA, Deering DW, Harlan JC (1974) Monitoring the vernal advancement and retrogadation (greenwave effect) of natural vegetation. Texas A\&M University Remote Sensing Center

Ruiz J, Bielza M, Garrido A, Iglesias A (2013) Managing drought economic effects through insurance schemes based on local water availability. Paper presented at 8th International Conference of European Water Resources Association, Porto, Portugal, 26-29 June 2013

Ruiz J, Bielza M, Garrido A, Iglesias A (2015) Dealing with drought in irrigated agriculture through insurance schemes: an application to an irrigation district in Southern Spain. Span J Agric Res 13(4):e0106

Ruiz-Sanchez M, Domingo R, Castel J (2010) Deficit irrigation in fruit trees and vines in Spain. Span J Agric Res 8:5-20

Schewe J, Heinke J, Gerten D, Haddeland I, Arnell NW, Clark DB et al. (2014) Multimodel assessment of water scarcity under climate change. Proceedings of the National Academy of Sciences of the 
United States of America 111(9):3245-3250

Sivakumar MVK, Motha RP, Wilhite DA, Wood DA (Eds.) (2011) Agricultural Drought Indices Proceedings of an expert meeting. In Agricultural Drought Indices 2-4 June 2010 (p. 205)

Skees J, Gober S, Varangis P, Lester R (2001) Developing rainfall-based index insurance in Morocco. Policy Research Working Paper 2577. World Bank, p. 44

Skees JR (2010) State of Knowledge Report — Data Requirements for the Design of Weather Index Insurance. GlobalAgrisk, Lexington, Kentucky

Skees JR, Barnett BJ, Collier B (2008) Background and context for Climate adaptation discussions. GlobalAgRisk, Lexintong, Kentucky

Skees JR, Black JR, Barnett BJ (1997) Designing and Rating an Area Yield Crop Insurance Contract. Am J Agr Econ 79(2):430-438

Spitzer JJ (1984) Variance Estimates in Models with the Box-Cox Transformation: Implications for Estimation and Hypothesis Testing. Rev Econ Stat 66(4):645-52

Stahl K, Blauhut V, Kohn I, Acácio V et al. (2012) A European drought impact report inventory (EDII): Design and test for selected recent droughts in Europe. Technical Report No. 3. Drought R\&SPI Project, European Commission

Thompson C, Supalla R, Martin D, Neely B, McMullen B (2009) Weather Derivatives as a Potential Risk Management Tool for Irrigators. In AWRA Summer Specialty Conference (pp. 1-6). http://digitalcommons.unl.edu/agecon_cornhusker/456/

Tobarra MA, Castro JP (2011) Incertidumbre hídrica y prima de riesgo en la agricultura de la cuenca del Segura. Atlantic Review of Economics 2:1-17

Tsiourtis N (2005) Cyprus. Options Méditerranéennes Series B 51:25-47

Turvey C (2001) Weather derivatives for specific event risks in agriculture. Rev Agr Econ 23(2):333-351

Turvey CG, Mclaurin MK (2012) Applicability of the Normalized Difference Vegetation Index (NDVI) in Index-Based Crop Insurance Design. Weather, Climate, and Society 4(4):271-284. doi:10.1175/WCAS-D-11-00059.1

Uku S (2011) Water management policies to improve surface irrigation. Albanian Journal of Agricultural Sciences 10(2):29-37

US Drought Portal (2015a) Crop Moisture Index.https://www.drought.gov/drought/content/productscurrent-drought-and-monitoring-drought-indicators/crop-moisture-index. Accessed June 2015

US Drought Portal (2015b) Palmer Drought Severity Index. https://www.drought.gov/drought/content/products-current-drought-and-monitoring-droughtindicators/palmer-drought-severity-index. Accessed June 2015

USBR (United States Bureau of Reclamation) (1992) Central Valley Project Improvement Act (CVPIA). http://www.usbr.gov/mp/cvpia/. Accessed June 2015

USBR (United States Bureau of Reclamation) (2008) Central Valley Project and State Water Project Operations Criteria and Plan Biological Assessment. USBR Web site. http://www.usbr.gov/mp/cvo/OCAP/docs/OCAP_BA_2008.pdf. Accessed 5 January 2016

USBR (United States Bureau of Reclamation) (2015) Report of Operations Monthly Delivery Tables. Central Valley Operation Office. https://www.usbr.gov/mp/cvo/deliv.html. Accessed June 2015

USDA (United States Department of Agriculture) (2015) Economics, Statistics and Market Information System. Agricultural Land Values and Cash Rents-Final Estimates. http://usda.mannlib.cornell.edu/MannUsda/viewDocumentInfo.do?documentID=1519. Accessed June 2015

Van Loon AF (2015) Hydrological drought explained. Wiley Interdisciplinary Reviews: Water 2(August):359-392. doi:10.1002/wat2.1085

Vedenov DV, Barnett BJ (2004) Efficiency of weather derivatives as primary crop insurance instruments. J Agr Resour Econ 29(3):387-403 
Wada Y, Van Beek LPH, Bierkens MFP (2011) Modelling global water stress of the recent past: on the relative importance of trends in water demand and climate variability. Hydrol Earth Syst Sc 15(12):3785-3808

Westlands Water District (2014) Deep Groundwater Conditions Report. http://wwd.ca.gov/wpcontent/uploads/2015/04/2014-deep-groundwater-conditions-report.pdf. Accessed January 2016

Westlands Water District (2015) Crop Acreage reports. http://wwd.ca.gov/news-and-reports/cropacreage-reports/. Accessed June 2015

Woodard JD, Garcia P (2008) Basis risk and weather hedging effectiveness. Agricultural Finance Review 68:99-117

World Bank (2005) Managing Agricultural Production Risk Managing Agricultural Production Risk. Washington DC

World Bank (2011) Weather index insurance for agriculture: guidance for development practitioners. Agriculture and rural development discussion paper. Washington DC

Zarembka P (1968) Functional Form in the Demand for Money. J Am Stat Assoc 63 (322):502-5011

Zargar A, Sadiq R, Naser B, Khan FI (2011) A review of drought indices. Environ Rev 19(NA):333-349

Zeff H, Characklis G (2013) Managing water utility financial risks through third-party index insurance contracts. Water Resour Res 49:1939-1951

Zeng L (2000) On the Basis Risk of Industry Loss Warranties. Journal of Risk Finance 1(4):27-32

Zeuli KA, Skees JR (2005) Rainfall Insurance: A Promising Tool for Drought Management. Int J Water Resour D 21(4):663-675 



\section{APPENDICES}

\section{A.1 Regulation framework in Central Valley in California}

\section{Regulation and date of publication}

Description and main regulatory constraints
1485 (D-1485). August

1978.

(California State Water

Resources Control Board 1978)

Central Valley Project Improvement Act

(CVPIA). October 1992

(USBR 1992)

Bay-Delta Accord in 1994

(California Department of

Water Resources 1994) and

Bay-Delta Plan1995.

State Water Board Decision 1641 (D-1641). 1999.

(California State Water Resources Control Board 2000)

Water Quality Control Plan (WQCP) for the San

Francisco Bay/SacramentoSan Joaquin Delta Estuary. December 2006.

(California State Water Resources Control Board 2006)

Biological Opinion FWS BO RPA. December 2008. (USBR 2008)
The D-1485 standards aim to protect the beneficial use of the water of the Sacramento-San Joaquin Delta (Delta) and Suisun Marsh. The Racanelli Decision in 1986 overturned D-1485 because its use of pre-project construction conditions as a measure of flows needed to protect existing water rights in the Delta focused on water rights instead of beneficial uses.

On October 30, 1992, Title 34 of Public Law 102-575, 1993-current known as the CVPIA was signed into law by the President. It mandates changes in management of the Central Valley Project, particularly for the protection, restoration, and enhancement of fish and wildlife. New regulations include: 800,000 acre-feet of water dedicated to fish and wildlife annually (section 3406 (b)(2)), water transfer provisions (section 3405), and no new water contracts until fish and wildlife goals are achieved (section 3404).

Initiated a long-term planning process to improve the Delta and increase the reliability of its water supply particularly for water quality standards. California Water Policy Council and Federal Ecosystem Directorate (CALFED) is created. Bay-Delta Plan was superseded by Water Quality Control Plan in 2005.

Primary purpose was to allocate responsibility for implementing the flow-dependent objectives of the 1995 Bay-Delta Plan (California Department of Water Resources 1994). D-1641 sets today's minimum outflow requirements for the Delta, delta cross channel operations, minimum river flows at Rio Vista, X2 requirements for salinity control, water temperature requirements, export restrictions through the exportinflow ration and Vernalis criteria, and salinity standards at Emmaton, Jersey Point, Rock Slough, and Collinsville.

Water Quality Control Plan (WQCP) supersedes the 1995 Bay-Delta Plan. WQCP is primarily a planning document that serves to identify the water quality objectives and the beneficial uses to be protected. Among other objectives, it defines Net Delta Outflow Index (NDOI) requirements and requirements for San Joaquin River flows at Vernalis.

National Marine Fisheries Service (NMFS) provides Reasonable and Prudent Alternatives (RPA) of the U.S. Fish and Wildlife Service (FWS) to protect Delta 2009-current Smelt. It sets additional X2 salinity requirements (FWS Action 4), and flow restrictions at Old and Middle River (FWS Actions 1-3).
Implementation

$1978-1986$

1995-2005

1999 -current

2005-current 
Regulation and date of publication

Biological Opinion NMFS BO RPA and conference opinion on the long-term operations of the Central Valley Project and State Water Project. June 2009 (National Marine Fisheries Service 2009)
Sets minimum flow requirements below Whiskeytown Dam at Clear Creek (NMFS Action 1.1.1), additional 2009 - current closure of the delta cross channel gates during flushing flows in Oct-Dec (NMFS Action 4.1.2), limited CVP and SWP exports in April and May (NMFS 4.2.1), and minimum flow requirements below Goodwin Dam on the Stanislaus River (NMFS 3.1.3).

\section{A.2 CalLite estimations}

CalLite is an interactive screening model that simulates the hydrology of the Central Valley, reservoir operations, and delivery allocation decisions over an 82 year planning period (19222003) (California Department of Water Resources and United States Bureau of Reclamation 2014). The software also allows the user to select different water management regulation regimes to test how these regulations affect the water supply system. Some of the Delta regulatory controls depend on the water year hydrologic classification (Wet, Above Normal, Below Normal, Dry and Critical) which is based on the Sacramento Index.

\section{3-2003 estimations}

To test the accuracy of CalLite in estimating historical water deliveries, actual monthly deliveries in the CVP during the period (1993-2003) were compared with estimated deliveries in CalLite (in CalLite the sum of water delivered to North of the Delta and South of the Delta are considered).

During the period 1993-2003, the regulatory framework changed (see Appendix A.1). In consequence, two regulatory frameworks are simulated. The actual deliveries in the period 1993-1998, were compared to deliveries estimated in CalLite using Central Valley Improvement Act (CVPIA) regulations that were in place at the time: flow regulations at Clear Creek and at the upper Sacramento River (consisting of the predetermined CVPIA 3406 (b) (2) flows). The actual deliveries in the period 1999-2003 are compared to deliveries estimated in CalLite under a regulatory regime that includes D-1641 regulations (see Appendix A.1). CalLite also allows for alternative climate change projections, alternative scenarios of sea level, alternative levels of water demands and several future management actions. For both scenarios, these variables were set at their base level. 


\section{A.3 Stochastic simulation of Sacramento Index conditioned on the value of the Sacramento Index in previous year}

$\underline{\text { Sacramento Index components }}$

Tables A1, A2, and A3 contain summary statistics from the Sacramento Index Components' distribution fitting. Figure A1 presents pairwise correlations among the Sacramento Index components.

Table A1. Summary statistics from Oct-Mar distribution fitting

\begin{tabular}{lcc}
\hline Oct-Mar & Entry data & $\begin{array}{c}\text { Gamma (Threshold } \theta, \text { Scale } \sigma, \text { Shape } \alpha) \\
\text { Gamma }(2.14,3.50,2.25)\end{array}$ \\
\cline { 1 - 3 } p value K-S test & & $>0.25$ \\
\hline Min & 2.49 & 2.145 \\
Max & 22.75 & $\infty$ \\
Mean & 10.051 & 10.051 \\
Mode & $\approx 6.263$ & 6.546 \\
Median & 8.4 & 8.918 \\
Standard dev & 5.094 & 5.264 \\
Asymmetry & 0.7205 & 1.3316 \\
Kurtosis & 2.468 & 5.6598 \\
\hline
\end{tabular}

Table A2. Summary statistics from Apr-Jul distribution fitting

\begin{tabular}{lcc}
\hline Apr-Jul & Entry data & $\begin{array}{c}\text { Gamma (Threshold } \theta, \text { Scale } \sigma, \text { Shape } \alpha \text { ) } \\
\text { Gamma }(1.44,2.04,2.49)\end{array}$ \\
\cline { 1 - 2 } p value K-S test & & $>0.5$ \\
\hline Min & 1.93 & 1.439 \\
Max & 13.68 & $\infty$ \\
Mean & 6.505 & 6.505 \\
Mode & $\approx 4.383$ & 4.467 \\
Median & 5.92 & 5.844 \\
Standard dev & 3.059 & 3.212 \\
Asymmetry & 0.702 & 1.2683 \\
Kurtosis & 2.6858 & 5.4129 \\
\hline
\end{tabular}


Table A3. Summary statistics from lagged Sacramento Index distribution fitting

\begin{tabular}{lcc}
\hline SI $_{\mathrm{t}-1}$ & Entry data & $\begin{array}{c}\text { Gamma (Threshold } \theta, \text { Scale } \sigma, \text { Shape } \alpha) \\
\text { Gamma }\end{array}$ \\
\cline { 1 - 2 } $\mathrm{p}$ value K-S test & & $>0.25$ \\
\hline Min & 3.11 & 1.755 \\
Max & 15.29 & $\infty$ \\
Mean & 7.884 & 7.884 \\
Mode & $\approx 6.200$ & 6.715 \\
Median & 7.16 & 7.499 \\
Standard dev & 2.634 & 2.677 \\
Asymmetry & 0.5411 & 0.8734 \\
Kurtosis & 2.6715 & 4.1442 \\
\hline
\end{tabular}

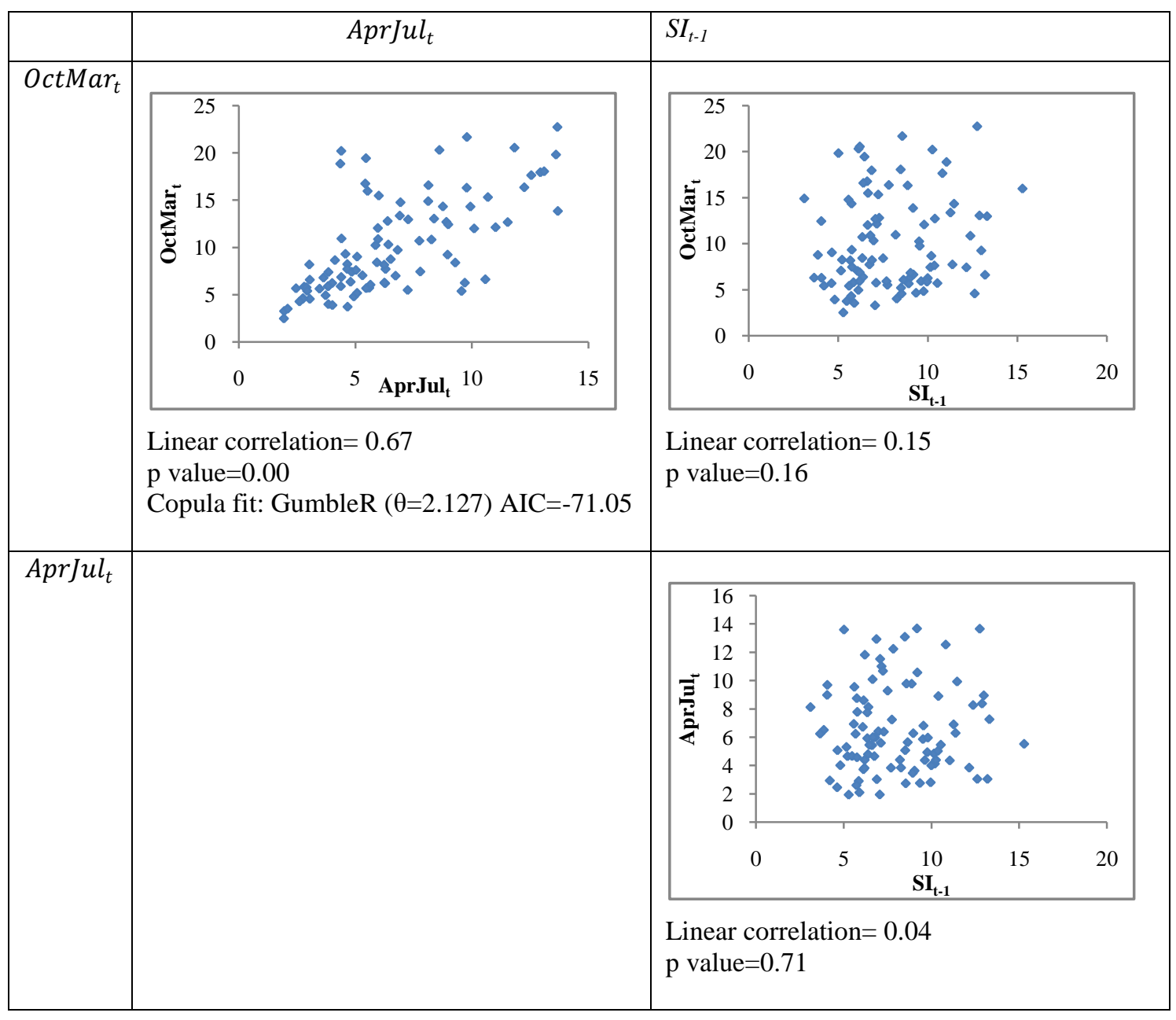

Figure A1. Pairwise correlations between Sacramento Valley 40-30-30 Index components (1922-2014) $\underline{\text { Sacramento Index conditional distributions }}$

Tables A4 to A8 contain summary statistics for the Sacramento Index conditional distributions. Distributions were fit using 5,000 draws from the simulated Sacramento Index components 
conditional on $\mathrm{SI}_{\mathrm{t}-1}$ being equal to 2, 4, 6, 8, and 10 in tables $\mathrm{A} 4, \mathrm{~A} 5, \mathrm{~A} 6, \mathrm{~A} 7$, and $\mathrm{A} 8$, respectively.

Table A4. Summary statistics from $\mathrm{SI}_{\mathrm{t}} \mid \mathrm{Si}_{\mathrm{t}-1}=2$ distribution fitting

\begin{tabular}{lcc}
\hline $\mathrm{SI}_{\mathrm{t}} \mid \mathrm{SI}_{\mathrm{t}-1=2}$ & Entry data & $\begin{array}{c}\text { Gamma (Threshold } \theta, \text { Scale } \sigma, \text { Shape } \alpha) \\
\text { Gamma }(1.69,1.55,2.92)\end{array}$ \\
\cline { 1 - 2 } $\mathrm{p}$ value K-S test & & $=0.15$ \\
\hline Min & 1.885 & 1.689 \\
Max & 22.41 & $\infty$ \\
Mean & 6.217 & 6.217 \\
Mode & $\approx 3.692$ & 4.667 \\
Median & 5.755 & 5.712 \\
Standard dev & 2.618 & 2.649 \\
Asymmetry & 1.0824 & 1.1702 \\
Kurtosis & 4.684 & 5.054 \\
\hline
\end{tabular}

Table A5. Summary statistics from $\mathrm{SI}_{\mathrm{t}} \mid \mathrm{Si}_{\mathrm{t}-1}=4$ distribution fitting

\begin{tabular}{lcc}
\hline $\mathrm{SI}_{\mathrm{t}} \mid \mathrm{Si}_{\mathrm{t}-1}=4$ & Entry data & $\begin{array}{c}\text { Gamma (Threshold } \theta, \text { Scale } \sigma, \text { Shape } \alpha) \\
\text { Gamma }(2.29,1.55,2.92)\end{array}$ \\
\cline { 1 - 3 } $\mathrm{p}$ value K-S test & & $=0.15$ \\
\hline Min & 2.485 & 2.289 \\
Max & 23.01 & $\infty$ \\
Mean & 6.817 & 6.817 \\
Mode & $\approx 4.292$ & 5.267 \\
Median & 6.355 & 6.312 \\
Standard dev & 2.618 & 2.649 \\
Asymmetry & 1.0824 & 1.1702 \\
Kurtosis & 4.684 & 5.054 \\
\hline
\end{tabular}

Table A6. Summary statistics from $\mathrm{SI}_{\mathrm{t}} \mid \mathrm{Si}_{\mathrm{t}-1}=6$ distribution fitting

\begin{tabular}{lcc}
\hline $\mathrm{SI}_{\mathrm{t}} \mid \mathrm{Si}_{\mathrm{t}-1}=6$ & Entry data & $\begin{array}{c}\text { Gamma (Threshold } \theta, \text { Scale } \sigma, \text { Shape } \alpha) \\
\text { Gamma }(2.89,1.55,2.92)\end{array}$ \\
\hline $\mathrm{p}$ value K-S test & & $=0.15$ \\
\hline Min & 3.085 & 2.889 \\
Max & 23.61 & $\infty$ \\
Mean & 7.417 & 7.417 \\
Mode & $\approx 4.892$ & 5.867 \\
Median & 6.955 & 6.912 \\
Standard dev & 2.618 & 2.649 \\
Asymmetry & 1.0824 & 1.1702 \\
Kurtosis & 4.684 & 5.054 \\
\hline
\end{tabular}


Table A7. Summary statistics from $\mathrm{SI}_{\mathrm{t}} \mid \mathrm{Si}_{\mathrm{t}-1}=8$ distribution fitting

\begin{tabular}{lcc}
\hline $\mathrm{SI}_{\mathrm{t}} \mid \mathrm{Si}_{\mathrm{t}-1}=8$ & Entry data & $\begin{array}{c}\text { Gamma (Threshold } \theta, \text { Scale } \sigma, \text { Shape } \alpha) \\
\text { Gamma }(3.49,1.55,2.92)\end{array}$ \\
\hline $\mathrm{p}$ value K-S test & & $=0.15$ \\
\hline Min & 3.685 & 3.489 \\
Max & 24.21 & $\infty$ \\
Mean & 8.017 & 8.017 \\
Mode & $\approx 5.492$ & 6.467 \\
Median & 7.555 & 7.512 \\
Standard dev & 2.618 & 2.649 \\
Asymmetry & 1.0824 & 1.1702 \\
Kurtosis & 4.684 & 5.054 \\
\hline
\end{tabular}

Table A8. Summary statistics from $\mathrm{SI}_{\mathrm{t}} \mid \mathrm{Si}_{\mathrm{t}-1}=10$ distribution fitting

\begin{tabular}{lcc}
\hline $\mathrm{SI}_{\mathrm{t}} \mid \mathrm{Si}_{\mathrm{t}-1}=10$ & Entry data & $\begin{array}{c}\text { Gamma (Threshold } \theta, \text { Scale } \sigma, \text { Shape } \alpha) \\
\text { Gamma }(4.09,1.55,2.92)\end{array}$ \\
\hline $\mathrm{p}$ value K-S test & & $=0.15$ \\
\hline Min & 4.285 & 4.089 \\
$\mathrm{Max}$ & 24.81 & $\infty$ \\
Mean & 8.617 & 8.617 \\
Mode & $\approx 6.092$ & 7.067 \\
Median & 8.155 & 8.112 \\
Standard dev & 2.618 & 2.649 \\
Asymmetry & 1.0824 & 1.1702 \\
Kurtosis & 4.684 & 5.054 \\
\hline
\end{tabular}



